\title{
Geodynamics, seismicity, and seismic hazards of the Caucasus
}

Alik Ismail-Zadeh ${ }^{\mathrm{a}, \mathrm{b}, *}$, Shota Adamia ${ }^{\mathrm{c}}$, Aleksandre Chabukiani ${ }^{\mathrm{c}}$, Tamaz Chelidze ${ }^{\mathrm{c}}$, Sierd Cloetingh ${ }^{\mathrm{d}}$, Michael Floyd ${ }^{\mathrm{e}}$, Alexander Gorshkov ${ }^{\mathrm{b}}$, Alexei Gvishiani ${ }^{\mathrm{f}}$, Tahir Ismail-Zadeh ${ }^{\mathrm{g}}$, Mikhail K. Kaban ${ }^{\text {h,i }}$, Fakhraddin Kadirov ${ }^{g}$, Jon Karapetyan', Talat Kangarli ${ }^{g}$, Jemal Kiriac ${ }^{\mathrm{c}}$, Ivan Koulakov ${ }^{k, 1}$, Jon Mosar ${ }^{\mathrm{m}}$, Tea Mumladze ${ }^{\mathrm{c}}$, Birgit Müller ${ }^{\mathrm{a}}$, Nino Sadradze ${ }^{\mathrm{c}}$, Rafig Safarov ${ }^{\mathrm{g}}$, Frank Schilling ${ }^{\mathrm{a}}$, Alexander Soloviev ${ }^{\mathrm{b}}$

${ }^{a}$ Karlsruhe Institute of Technology, Institute of Applied Geosciences, Karlsruhe, Germany

b Institute of Earthquake Prediction Theory and Mathematical Geophysics, Russian Academy of Sciences, Moscow, Russia

' Javakhishvili Tbilisi State University, Nodia Institute of Geophysics, Tbilisi, Georgia

${ }^{\mathrm{d}}$ Utrecht University, Department of Earth Sciences, Utrecht, the Netherlands

${ }^{\mathrm{e}}$ Massachusetts Institute of Technology, Department of Earth, Atmospheric and Planetary Sciences, Cambridge, MA, USA

${ }^{\mathrm{f}}$ Geophysical Center, Russian Academy of Sciences, Moscow, Russia

${ }^{g}$ Azerbaijan National Academy of Sciences, Institute of Geology and Geophysics, Baku, Azerbaijan

${ }^{\mathrm{h}}$ Helmholtz-Centre Potsdam, GFZ German Research Centre for Geosciences, Telegrafenberg, Potsdam, Germany

${ }^{i}$ Schmidt Institute of Physics of the Earth, Russian Academy of Sciences, Moscow, Russia

${ }^{\mathrm{j}}$ National Academy of Sciences of the Republic of Armenia, Nazarov Institute of Geophysics and Engineering Seismology, Gyumri, Armenia

- ${ }^{\mathrm{k}}$ Trofimuk Institute of Petroleum Geology and Geophysics, Siberian Branch of the Russian Academy of Sciences, Novosibirsk, Russia

${ }^{1}$ Novosibirsk State University, Novosibirsk, Russia

${ }^{\mathrm{m}}$ University of Fribourg, Department of Geosciences, Fribourg, Switzerland

A R T I C L E I N F O

\section{Keywords:}

Greater and Lesser Caucasus

Geological evolution

Geodesy

Gravity

Density

Deformation

Tectonic stresses

Seismic tomography

\section{A B S T R A C T}

Being a part of ongoing continental collision between the Arabian and Eurasian plates, the Caucasus region is a remarkable site of moderate to strong seismicity, where devastating earthquakes caused significant losses of lives and livelihood. In this article, we survey geology and geodynamics of the Caucasus and its surroundings; magmatism and heat flow; active tectonics and tectonic stresses caused by the collision and shortening; gravity and density models; and overview recent geodetic studies related to regional movements. The tectonic development of the Caucasus region in the Mesozoic-Cenozoic times as well as the underlying dynamics controlling its development are complicated processes. It is clear that the collision is responsible for a topographic uplift / inversion and for the formation of the fold-and-thrust belts of the Greater and Lesser Caucasus. Tectonic deformations in the region is influenced by the wedge-shaped rigid Arabian block indenting into the relatively mobile region and producing near N-S compressional stress and seismicity in the Caucasus. Regional seismicity is analysed with an attention to sub-crustal seismicity under the northern foothills of the Greater Caucasus, which origin is unclear - whether the seismicity associated with a descending oceanic crust or thinned continental crust. Recent seismic tomography studies are in favour of the detachment of a lithospheric root beneath the Lesser and Greater Caucasus. The knowledge of geodynamics, seismicity, and stress regime in the Caucasus region assists in an assessment of seismic hazard and risk. We look finally at existing gaps in the current knowledge and identify the problems, which may improve our understanding of the regional evolution, active tectonics, geodynamics, shallow and deeper seismicity, and surface manifestations of the lithosphere dynamics. Among the gaps are those related to uncertainties in regional geodynamic and tectonic evolution (e.g., continental collision and associated shortening and exhumation, lithosphere structure, deformation and strain-stress partitioning) and to the lack of comprehensive datasets (e.g., regional seismic catalogues, seismic, gravity and geodetic surveys).

\footnotetext{
* Corresponding author at: KIT-AGW, Adenauerring 20b, 76131 Karlsruhe, Germany.

E-mail address: alik.ismail-zadeh@kit.edu (A. Ismail-Zadeh).
} 


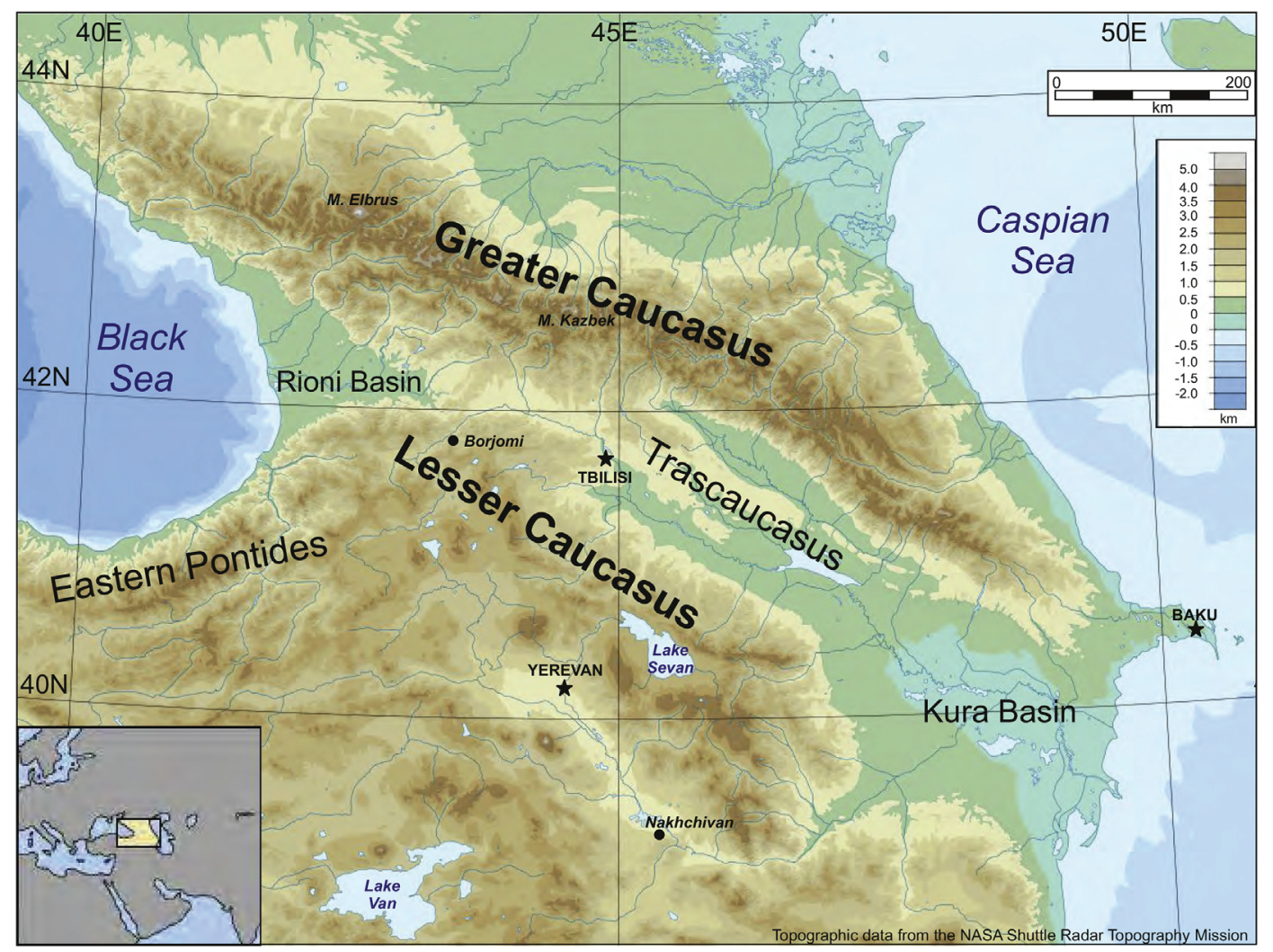

Fig. 1. Topographic map of the Caucasus and the surrounding area.

\section{Introduction}

Located between the Black Sea to the west and the Caspian Sea to the east (Fig. 1), the Caucasus region links Asia with Europe. The region is geographically subdivided into the North Caucasus known also as the Ciscaucasus (i.e. the area north of the Greater Caucasus), and the South Caucasus known also as Transcaucasus (i.e. the area south of the Greater Caucasus). The region hosts the Greater and Lesser Caucasian Mountains including Mount Elbrus, Europe's highest peak reaching $5642 \mathrm{~m}$ above sea level. According to Pliny the Elder (1855, p. 34), Scythians called the Caucasus "Graucasis", which means "white with snow".

The Caucasus region is a part of an ongoing continent-continent collision of the Arabian and Eurasian (AR-EU) plates, which is often compared to the collision zone between India and Eurasia during its early stages of evolution (e.g., Şengör and Kidd, 1979). A wider plate tectonic framework includes an active continental collision in eastern Turkey, the Caucasus, and the westward extrusion of Anatolia (McKenzie, 1970, 1972; Jackson and McKenzie, 1984, 1988; Philip et al., 1989). Convergence of Arabia and Africa with Eurasia has been occurring for more than 100 Ma. During this time span the Neotethys Ocean lithosphere has been subducting beneath Eurasia (Dewey et al., 1973; Khain, 1975; Adamia et al., 1977, 1981; Gamkrelidze, 1986).

Geological, geophysical, and geochemical studies add important details to the regional plate tectonic characterization, including (i) the westward movement of Anatolia accommodated by the North and East Anatolian faults (Şengor et al., 1985), (ii) partitioning of crustal deformation in the eastern Turkey/Caucasus continental collision zone (Jackson, 1992; Allen et al., 2004; Copley and Jackson, 2006), (iii) the influence of slab detachment on uplift and volcanism of the Turkish-Iranian plateau (e.g., Şengor et al., 2004; Barazangi et al., 2006), and (iv) the incipient subduction of the South Caspian oceanic basin beneath the North Caspian continental lithosphere along the Central Caspian Seismic Zone - CCSZ (e.g., Jackson et al., 2002).
The Greater Caucasus is thought to have formed by tectonic inversion of a former back-arc basin developed on continental crust, that opened during the early Mesozoic above the north-dipping subduction of the Neotethys (e.g., Adamia et al., 1981; Zonenshain and Le Pichon, 1986; Mosar et al., 2010). The eastern Black Sea and southern Caspian Sea are remnants of oceanic basin developed in Cretaceous and Jurassic times, respectively. Large foreland basins, such as the Kartli, Kuban, Kura, Rioni, or Terek basins, develop during the orogenic process in Tertiary times north and south of the Greater Caucasus range (e.g., Mosar et al., 2010). The Oligocene sedimentary fill of the Kura basin and of the Rioni basin is likely to be asymmetrical showing flexural subsidence along its southern margin, arguably the result of tectonic loading from the Lesser Caucasus (e.g., Nemčok et al., 2013).

Both the timing and spatial evolution of shortening and exhumation remain uncertain, with preferred estimates of the timing being Late Miocene to Early Pliocene (e.g., Kopp and Shcherba, 1985; Philip et al., 1989; Avdeev and Niemi, 2011; Albino et al., 2014; Cavazza et al., 2017, 2018). Meanwhile, using a thermochronological analysis, it was shown that the topography of the western Greater Caucasus started to grow during the Oligocene (Vincent et al., 2007, 2011). Total shortening across the Greater Caucasus is also uncertain with estimates ranging from 150 to $400 \mathrm{~km}$ (e.g., McQuarrie and van Hinsbergen, 2013) and with an increase in total shortening from west to east at present (e.g., Král and Gurbanov, 1996; Avdeev and Niemi, 2011; Forte et al., 2012). The continued convergence generated a compressive stress field reactivating the deformation and uplift of the Greater Caucasus in the Pliocene (e.g., Saintot and Angelier, 2002). Shallow seismicity is prevalent throughout the region, and sub-crustal earthquakes occur in the eastern part of the Greater Caucasus, beneath the Middle Caspian Sea, and along the edges of the south Caspian Sea beneath the Kura basin fill (e.g., Godzikovskaya and Reysner, 1989; Triep et al., 1995; Ulomov et al., 2007).

During the last several decades, significant research in regional geology, geodynamics, geodesy and geophysics was conducted to 
understand the evolution of the Caucasus and the surrounding areas as well as to elucidate the present tectonics, lithospheric deformation, seismicity, and associated seismic hazards and risks. The research results are recorded in many research articles published in international journals as well as in the journals published in the former Soviet Union, Armenia, Azerbaijan, Georgia, and Russia. This paper overviews the state-of-the-art knowledge in the geological and geophysical fields (internationally and locally) addressing the gaps in knowledge, and discusses the perspectives for future research combining expertise and experience of Armenian, Azeri, Georgian, and Russian scientists and their international colleagues. Doing so, we present a synthesis of the current understanding of geodynamics and seismicity of the Caucasus, highlighting different scientific views and trying to structure disjointed and contradictory research works associated with the topics. We describe different models and compare them against the data available, discuss still controversial points and possible ways to resolve them, and conclude the paper presenting examples of desired scientific research in the region.

\section{Geology and geodynamics}

The Caucasus located in the central part of the mobile AlpineHimalayan belt is the result of a continental collision between the AREU plates (Dewey et al., 1973; Khain, 1975; Adamia, 1975; Dercourt et al., 1986; Zonenshain and Le Pichon, 1986; Zonenshain et al., 1987; Philip et al., 1989; Okay and Şahintürk, 1997; Allen et al., 2004; Vincent et al., 2007; Zakariadze et al., 2007; Sosson et al., 2010a, 2017; Adamia et al., 2011, 2017; Albino et al., 2014; Cavazza et al., 2017; Alania et al., 2017). The ongoing interaction of these plates controls the present geodynamics and the seismicity of the Caucasus (McKenzie, 1972; Jackson and McKenzie, 1988; Ambraseys and Jackson, 1998; Berberian and Yeats, 1999; Allen et al., 2004; Panahi, 2006; Karakhanyan et al., 2013, 2017; Şeşetyan et al., 2018). The region can be sub-divided into several major tectonic units (Fig. 2a). It combines (from the north to the south) the Scythian platform with the Stavropol High and the Azov-Kuban and Terek-Kuma flexural foreland basins, the Greater Caucasus Fold-and-Thrust Belt (GCFTB), the Rioni and Kura basins superimposed mainly on the rigid platform blocks (e.g., the Dzirula crystalline massif), the Achara-Trialeti (also known as AjaraTrialeti) and the Talysh fold-thrust belts (FTB), the Lesser Caucasus FTB, the Sevan-Akera ophiolitic suture, the Lesser Caucasian part of the Taurus-Anatolia-Central Iranian platform, and the Aras intermontane basin (or the Aras flat). The Armenian and Javakheti highlands are composed of Neogene-Quaternary continental volcanic formations, and recent volcanoes of the Greater Caucasus are Elbrus, Chegem, Keli, and Kazbegi (Adamia et al., 2011, 2017).

Integrative geological and paleobiogeographical studies show a collage of several tectonic units in the Caucasus and adjoining areas that have distinctive geological histories with marine Tethyan, Eurasian, or Gondwanan affinities (Adamia et al., 2011, 2017). Their position between the African-Arabian and Eurasian plates provides a reason for grouping them into the North Tethyan (Eurasian) and South Tethyan (Gondwanan) domains (Fig. 2b). The Scythian platform, Greater Caucasus, and Lesser Caucasus - Transcaucasus-Pontian belts originate from the North Tethyan, while Anatolia, Taurus, Iran, and the southern Lesser Caucasus belong to the South Tethys (Stampfli et al., 2001; Zakariadze et al., 2007, 2012). At the end of the Proterozoic, the Arabia-Nubian shield experienced basement consolidation related to the final stages of the Pan-African cycle of deformation (Zakariadze et al., 2007, 2012). In contrast to the southernmost Caucasus (Daralagöz, Fig. 2b), the Transcaucasus did not undergo this process, because it broke away from the Arabia-Nubia shield and drifted far in the Prototethys toward the northern (Baltica) continent during Cambrian-Devonian times (Fig. 3a; Dercourt et al., 1986; Zonenshain et al., 1987, 1990; Barrier and Vrielynck, 2008; Barrier et al., 2018). As a consequence of northward-migrating Gondwanan fragments, the
Paleotethyan basin formed during the early-middle Paleozoic, and a subduction of the oceanic lithosphere began along its border with the Transcaucasus in the Ordovician, which was accompanied by volcanic eruptions. Northward migration of the Transcaucasus throughout the Paleozoic narrowed the Prototethys and transformed it into an oceanic back-arc (Dizi) basin (Fig. 3b). An evidence for back-arc type of the oceanic lithosphere beneath the Dizi basin comes from a Lower-Middle Paleozoic basite-ultrabasite-tonalite metamorphic complex representing the northernmost strip of the mafic series along the northern border of the basin. This complex is the largest pre-Upper Paleozoic oceanic unit in the southern slope zone of the Greater Caucasus. It is composed mainly of diverse tectonic slices of metamorphosed paleooceanic lithosphere (Adamia et al., 2011, 2017b, 2017a; Zakariadze et al., 2012).

During the late Paleozoic-Early Mesozoic, the oceanic basin separating the Africa-Arabian continent from the Taurus-Anatolian-Iranian domain gradually extended. During this phase, only the Central Iranian terrain separated from Gondwana, drifted northward, and collided with the Eurasian continent in the Late Triassic (Fig. 3c). The Taurus-Anatolian terrains separated from Gondwana later, in the Early-Middle Jurassic. During the Mesozoic-Cenozoic (Fig. 3d,e), Daralagöz (the South Armenian Block - Nakhchivan) represented the northwesternmost margin of the Central Iranian platform and was separated from the North Anatolian platform by an oceanic or back-arc Khoy basin, which in the recent structure is represented by Mesozoic-Cenozoic ophiolites of Urumieh-Khoy and Van (Dercourt et al., 1986; Knipper et al., 1987; Zonenshain et al., 1987). The structural relation of Daralagöz with respect to the Central Iranian platform is still a matter of debates. Particularly, some regional paleo-reconstructions (e.g., Barrier and Vrielynck, 2008; Barrier et al., 2018) suggest that during the Mesozoic-Cenozoic times, Daralagöz was a part of the Tauride-Anatolian platform. The basement of the Khoy basin is considered to be a part of the South Armenian Block, and the Khoy ophiolites to be obducted on the block from the Sevan-Akera suture zone (e.g., Avagyan et al., 2016; Sosson et al., 2016, 2019).

There were several episodes of oceanic lithospheric obduction onto the continental terranes of the region. During the Middle-Late Paleozoic obduction basite-ultrabasite complexes were thrust over the Caucasus island-arc. During the pre-Late Triassic obduction in the Lesser Caucasus (e.g., pre-Carnian breccia-conglomerates found in the ophiolite mélange to the east of the Lake Sevan; Knipper, 1991) and the pre-Late Jurassic obductions (e.g., the Oxfordian Tsopi suite in the southern part of Georgia; Adamia et al., 1989), ultrabasic rocks were thrust over the continental block of Daralagöz and the Artvin-Bolnisi zone (Knipper et al., 1987; Sosson et al., 2010b; Adamia et al., 2011, 2017). Redeposited Albian-Cenomanian ophioclastics (Knipper, 1975; Sokolov, 1977) and the Cenomanian-Santonian ophiolitic complexes (Gasanov, 1996) were found within the Sevan-Akera suture zone. The obduction occurred during the Late Coniacian to Santonian was responsible for the widespread ophiolitic nappe outcrop in front of the suture zone (Sosson et al., 2010b; Hässig et al., 2016, 2017).

The onset of the syn-collisional stage of the Caucasus tectonic evolution is associated with Oligocene (e.g., Adamia et al., 2017-c). The age of this continental collision has been the topic of much debates, with proposed ages ranging from the Late Cretaceous to the Pliocene (e.g., Hall, 1976; Berberian and King, 1981; Şengor et al., 1985; Dercourt et al., 1986; Adamia et al., 1990; Y1lmaz, 1993; Alavi, 1994; Okay and Şahintürk, 1997; Jolivet and Faccenna, 2000; Stampfli, 2000; Allen et al., 2004; Agard et al., 2005; Robertson et al., 2007; Allen and Armstrong, 2008; Okay et al., 2010; Adamia et al., 2010b; McQuarrie and van Hinsbergen, 2013; Cavazza et al., 2018). According to McQuarrie and van Hinsbergen (2013), the Neotethys ocean's closure north of the Arabian Plate occurred about $27 \mathrm{Ma}$, while ocean subduction continues at present along the Hellenic and Cyprus trenches. Cowgill et al. (2016) interpreted the AR-EU collision zone's reorganization by the closure of the former rift basin (the southern slope 


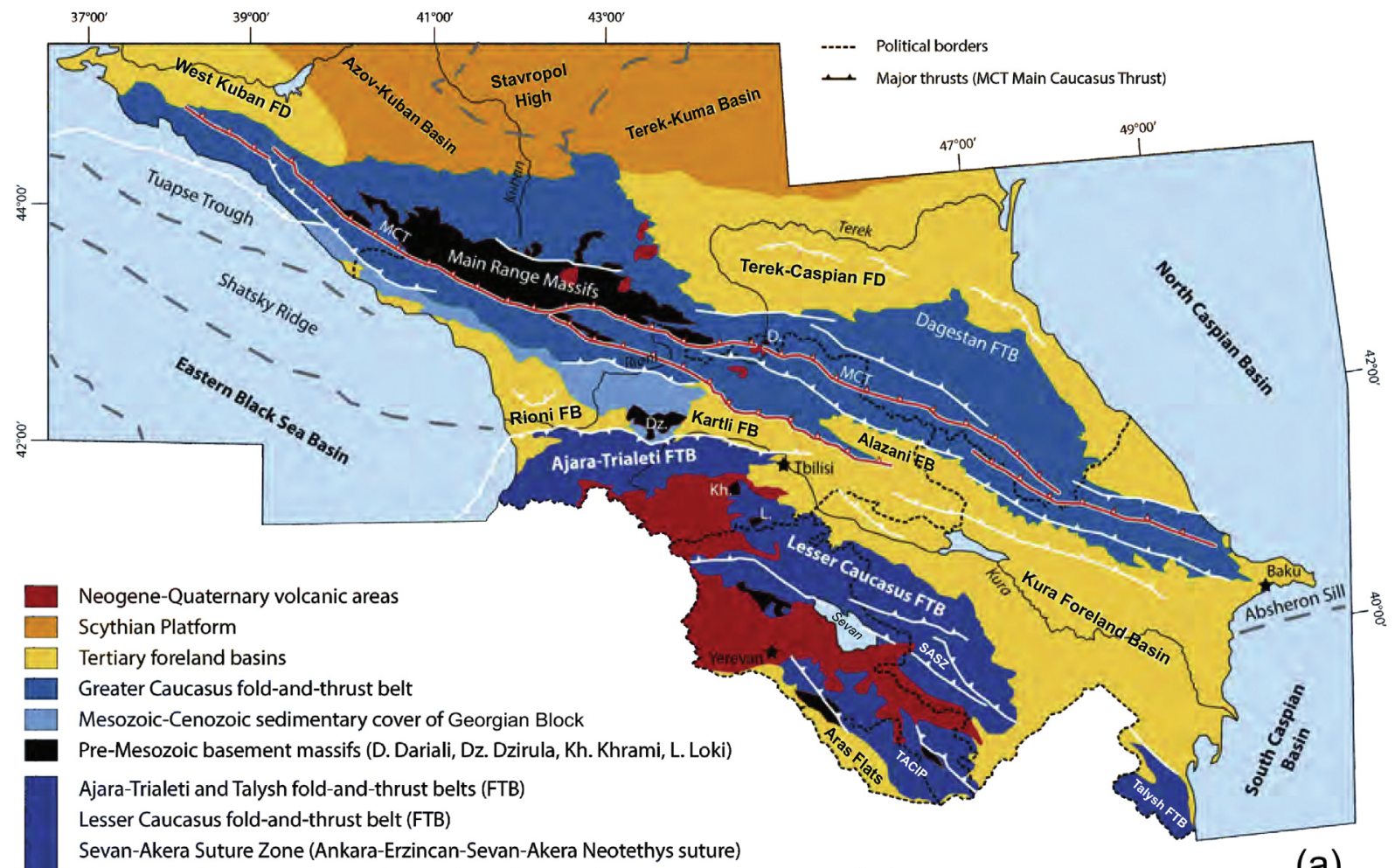

Taurus-Anatolian-Central Iranian Platform (Taurides-Anatolides-South Armenian Microplate)

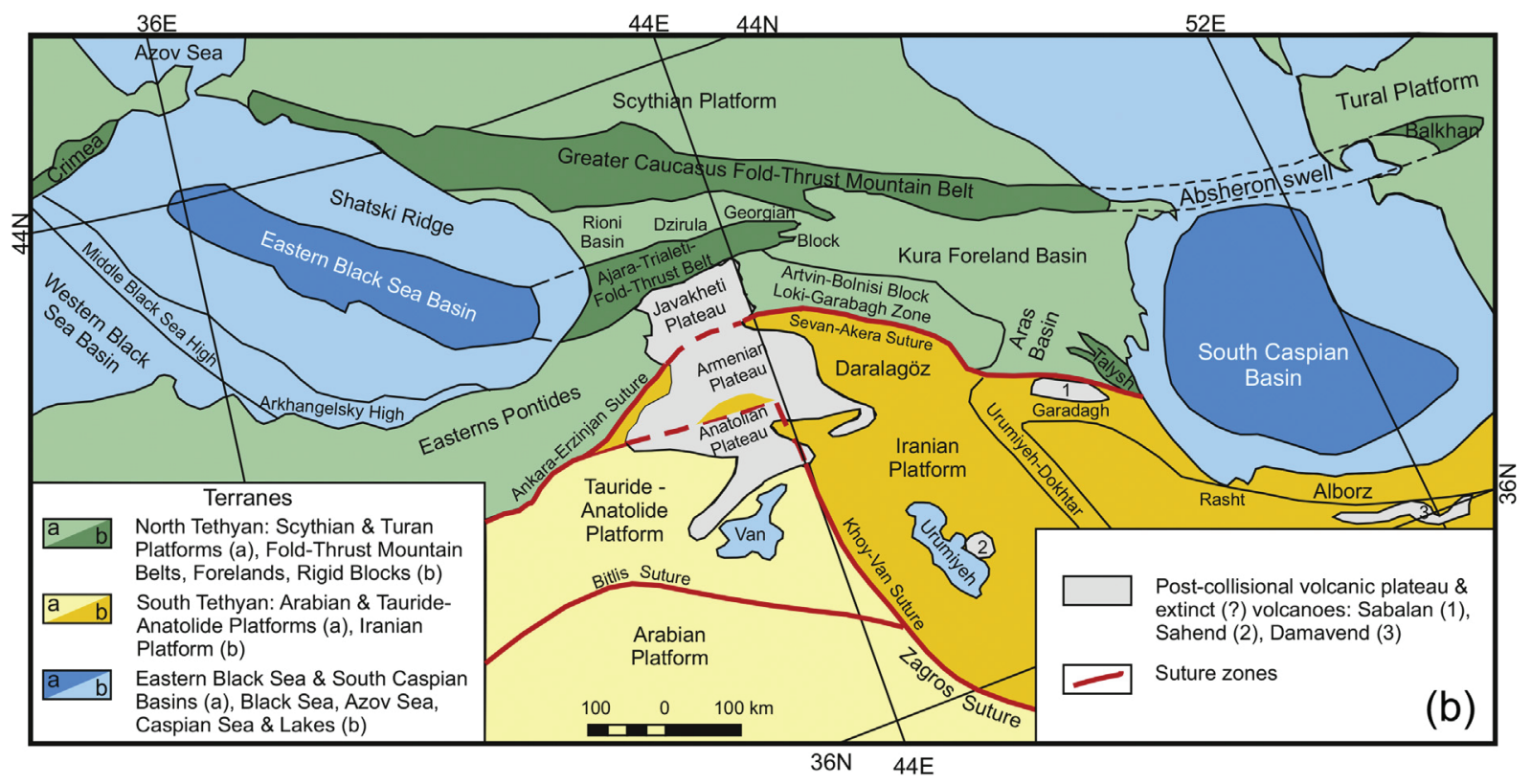

Fig. 2. (a) Main tectonic units of the Caucasus. SASZ: the Sevan-Akera Suture Zone; TACIP: the Taurus-Anatolian-Central Iranian Platform; FD: foredeep; MCT: the Main Caucasus Thrust; FTB: fold-and-thrust belt. (b) Correlation map of the main tectonic units of the Caucasus and adjacent areas (modified after Adamia et al., 2011).

of the Greater Caucasus mountains). However, Vincent et al. (2018) argued that at least within the western Greater Caucasus, sedimentological, provenance, and seismic data supports an earlier basin closure age in Early Oligocene. Cowgill et al. (2018) suggested that the closure of the basin initiated at about 35 My ago and ended at about 5 My ago following the collision between the Lesser Caucasus and the Scythian platform to form the Greater Caucasus. The basic underlying assumption related to the collision is that the Greater Caucasus results from farfield transmission of tectonic stresses from the Bitlis-Zagros collision zone.

The final collision of the AR-EU plates and formation of the present intracontinental mountainous edifice of the Caucasus occurred in the Neogene-Quaternary (Cavazza et al., 2017, 2018, 2019). The collision between the AR-EU plates caused a topographic uplift (inversion), and the fold-and-thrust belts of the Greater and Lesser Caucasus were formed (Mosar et al., 2010; Cavazza et al., 2019). Associated with the orogenic climax during the Late Miocene (9-7 Ma) to Pleistocene (e.g., Adamia et al., 2010a, 2017), the central part of the region is subject to 


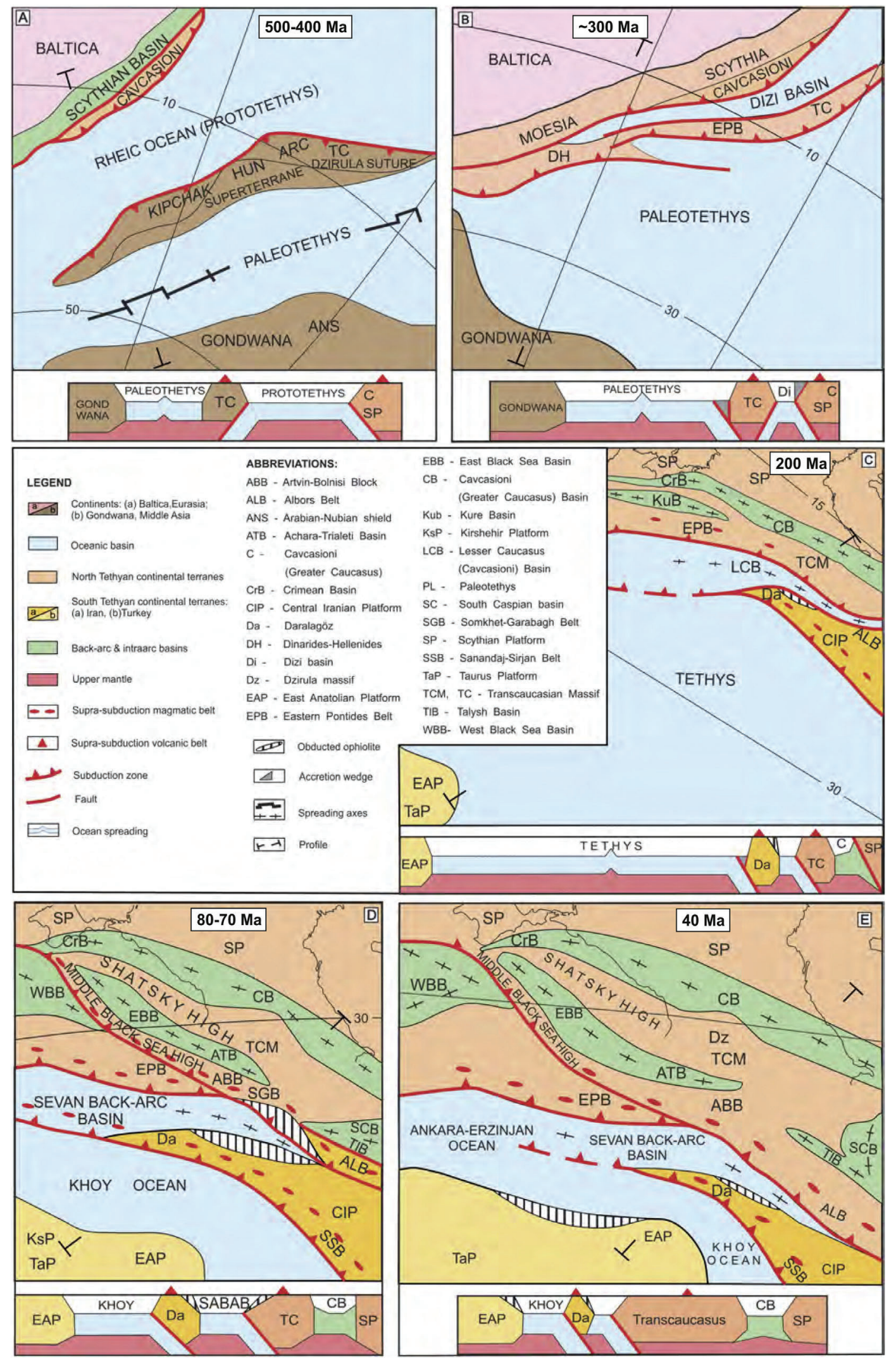

Fig. 3. Paleotectonic reconstructions of the Caucasus and adjacent areas: (a) Early Middle Paleozoic; (b) Late Paleozoic; (c) Early Mesozoic; (d) Late Mesozoic; and (e) Early Cenozoic (modified after Adamia et al., 2011). 
subaerial volcanic eruptions (Mitchell and Westaway, 1999). About 5 My ago, a regional reorganization of the AR-EU collision zone, likely to be triggered by oceanic spreading in the Red Sea (Cochran, 1983; Allen et al., 2002), intensified the topographic uplift and denudation in the Caucasus (Adamia et al., 2011).

\section{Magmatism and heat flow}

The Paleozoic-Paleogene evolution of the Caucasian domain was marked by major magmatic events (Fig. 3). The pre-collisional magmatic assemblages reflect a variety of paleogeographic environments. They are indicative of a west Pacific-type oceanic setting in which a mature continental arc developed. Paleozoic magmatism is traced at Nakhchivan, where gabbro-dolerite sills are widespread in the Devonian-Carboniferous series (Azizbekov, 1972). Evidences of Jurassic and Cretaceous magmatism can be found in the southern slope of the Greater Caucasus (e.g., McCann et al., 2010). The tholeitic-basalt and alkali magmatism was associated with the rifting during Early-Middle Jurassic times, gabbro-diorite-plagiogranite dikes were formed during the Late Jurassic, and outcrops of the Middle Jurassic andesite-basalt and trachybasalt magmatism can be found in the region (Khain, 1975; Adamia et al., 1977, 1981; Mustafaev, 2000, 2003). Some evidences for the Early Jurassic magmatism (ultrabasites and gabbroids) can also be found in the Lesser Caucasus and Nakhchivan (Galoyan et al., 2007, 2009; Hässig et al., 2013). The Middle Jurassic island arc magmatism lead to volcanic rock formation with basalt-rhyolite and basalt-andesite-dacite-rhyolite composition in the places, where the Lesser Caucasus and the Kura basin were formed. Intensive Late Jurassic magmatism in the same places (the current Lesser Caucasus, e.g., LokiKarabakh, and the Kura basin) produced mainly basaltic, andesitic, dacitic and rhyolitic magmas and gabbroic dikes (Lordkipanidze et al., 1989; Mederer et al., 2013). In the Lesser Caucasus, Early Cretaceous andesite-basalt volcanism occurred in the Loki-Karabakh zone. Late Cretaceous magmatism was accompanied by intensive volcanic activity in the Lesser Caucasus (e.g., Loki-Karabakh-Kaphan), the Kura basin, and the Greater Caucasus. This volcanism had basalt-andesite-daciterhyolite composition in the Lesser Caucasus, and basalt-andesite and trachybasalt in the Greater Caucasus and Kura basin (Lordkipanidze, 1989; Dilek et al., 2009; Mederer et al., 2013). Cenozoic magmatism in the Lesser Caucasus and Talysh is associated with extensional processes, and the related volcanism had basalt-andesite-dacite and sub-alkaline composition (e.g., Adamia et al., 1977, 1981; Lordkipanidze et al., 1989). Products of the Cenozoic volcanism include batholiths in the south, and intrusive masses in the centre of the Lesser Caucasus (Lordkipanidze et al., 1989; Mederer et al., 2013; Sahakyan et al., 2017; Van der Boon et al., 2017).

The Late Cenozoic AR-EU collision was coeval with the NeogeneQuaternary sub-aerial volcanism that occurred from the Middle East through the Caucasus to southern Russia (Fig. 2). Outcrops of the postcollisional magmatic rocks are exposed along the boundaries of the major tectonic units of the region, for example, near the Van and Urmieh lakes. The volcanic zone extended northward forms the East Anatolian, Armenia-Azerbaijan, and South Georgian volcanic highlands and chains of recent volcanoes in the Lesser Caucasus - Transcaucasus region. The northernmost relatively short WNW-ESE branch of syn- and post-collisional magmatic formations located in the central segment of the Caucasus is connected to the boundary zone between the GCFTB and the Scythian platform (Adamia et al., 2011, 2017). Some evidences of relatively intensive manifestations of syn- and post-collisional magmatism are found within all tectonic units of the Caucasus. However, the most intensive magmatism occurred in the rigid platform units.

Magmatism, metamorphism, earthquakes, and volcanoes are controlled by the heat transfer from the deep Earth interior. The thermal budget regulates the dynamics of the lithosphere and asthenosphere. A three-dimensional steady-state thermal model for the Caucasus and the adjacent areas of the Black sea and Caspian Sea (Fig. 4 a,b) was developed by Alexidze et al. (1993) using seismic and gravity models of the lithosphere (Shengelaya, 1984) and assuming the effect of radioactive elements in the lithosphere and temperature of $1600{ }^{\circ} \mathrm{C}$ at a depth of $210 \mathrm{~km}$ (Pollack and Chapman, 1977). Surface heat flow data (Kutas et al., 1978) were used to validate the model results, and the density and thermal characteristics of the model were obtained from laboratory experiments on regional rock samples (Shengelaya, 1984). The thermal model shows the elevated temperatures up to $600 \mathrm{C}^{\circ}$ at the basement (Fig. 4a) within the eastern Black Sea and South Caspian Sea, and up to $750 \mathrm{C}^{\circ}$ at the Moho depths (Fig. 4b) beneath the central and eastern parts of the Greater Caucasus and the Lesser Caucasus. There is a reasonably satisfactory agreement between the thermal model of Alexidze et al. (1993) and those developed for the western Black Sea, northern Turkey, and Crimea (Tesauro et al., 2009, 2010) and for the southern Black Sea and Lesser Caucasus (Artemieva and Shulgin, 2019). Also, the thermal model is in general agreement (i) with the local Pwave tomography model (Zabelina et al., 2016), showing negative seismic velocity anomalies at the depth of $30 \mathrm{~km}$ in the same parts of the Greater and Lesser Caucasus, which is likely to be associated with higher temperature at the depths, and (ii) with known past volcanic activities (Fig. 11b). Geothermal gradients from the depth of $4 \mathrm{~km}$ were estimated from the available data on heat flow measurements in boreholes in the Caucasus region (Kerimov et al., 1989). High geothermal gradients of about $50-55{ }^{\circ} \mathrm{C}$ per $1000 \mathrm{~m}$ are revealed to the north of the region in the Stavropol area of Russia and in the south of the region in the Ankavan-Zangezur area of Armenia, the zone of the recent volcanism (Fig. 4c).

\section{Active tectonics and tectonic stress}

As a result of the continuing northward push of the Africa-Arabian plate in post-Oligocene times, the Caucasus region has become an intracontinental mountain belt, with active structures and topography (high mountain ranges of the Greater and Lesser Caucasus, intermontane lowlands of the Transcaucasus, and volcanic highlands) intensely developed since the late Sarmatian Stage. The post-collisional subhorizontal shortening of the Caucasus is estimated at hundreds of kilometres (Barrier and Vrielynck, 2008; Meijers et al., 2015). Such a considerable crustal shortening has occurred in the region through (i) compressional deformation by folds and thrusts, reverse faults, and nappes; (ii) warping and displacement of crustal blocks by uplift and subsidence; and (iii) lateral tectonic escape. The geometry of tectonic deformation in the region is largely determined by the wedge-shaped rigid Arabian block intensively indenting into the relatively mobile area (e.g. Jackson and Ambraseys, 1997; Okay and Şahintürk, 1997; Yilmaz et al., 1997; Ambraseys and Jackson, 1998; Berberian and Yeats, 1999; McClusky et al., 2000; Koçyiğit et al., 2001; Allen et al., 2003; Vincent et al., 2005). All structural-morphological lines have a clearly expressed arcuate northward-convex configuration reflecting the contours of the Arabian block (Axen et al., 2001; Allen et al., 2003; Reilinger et al., 2006), with some exceptions, e.g., the Achara-Trialeti structure trending E-W. GCFTB extends in the WNW-ESE direction, while the chains of Neogene-Quaternary volcanoes in the Lesser Caucasus are oriented in a sub-meridional (N-S) direction, which is also in compliance with the general NNE-SSW sub-horizontal compression of the region (Avagyan et al., 2005, 2010).

The geometry of tectonic structures in the Transcaucasian region may be seen in the frame of the wedge-shaped rigid Arabian block intensively indenting onto an area made of volcanic arc crust and accreted blocks, unlike the Greater Caucasus Basin (Fig. 3, c-e) to the north that developed on stretched continental crust and by the time of the main collision is inverted. The Greater Caucasus shows a change in structural style along strike from west to east. In the western and central segments, the orogeny is cored by large basement units that are thrust to the south, whereas no basement is outcropping to the east, where the core of the mountain belt is made of the thick inverted basin 

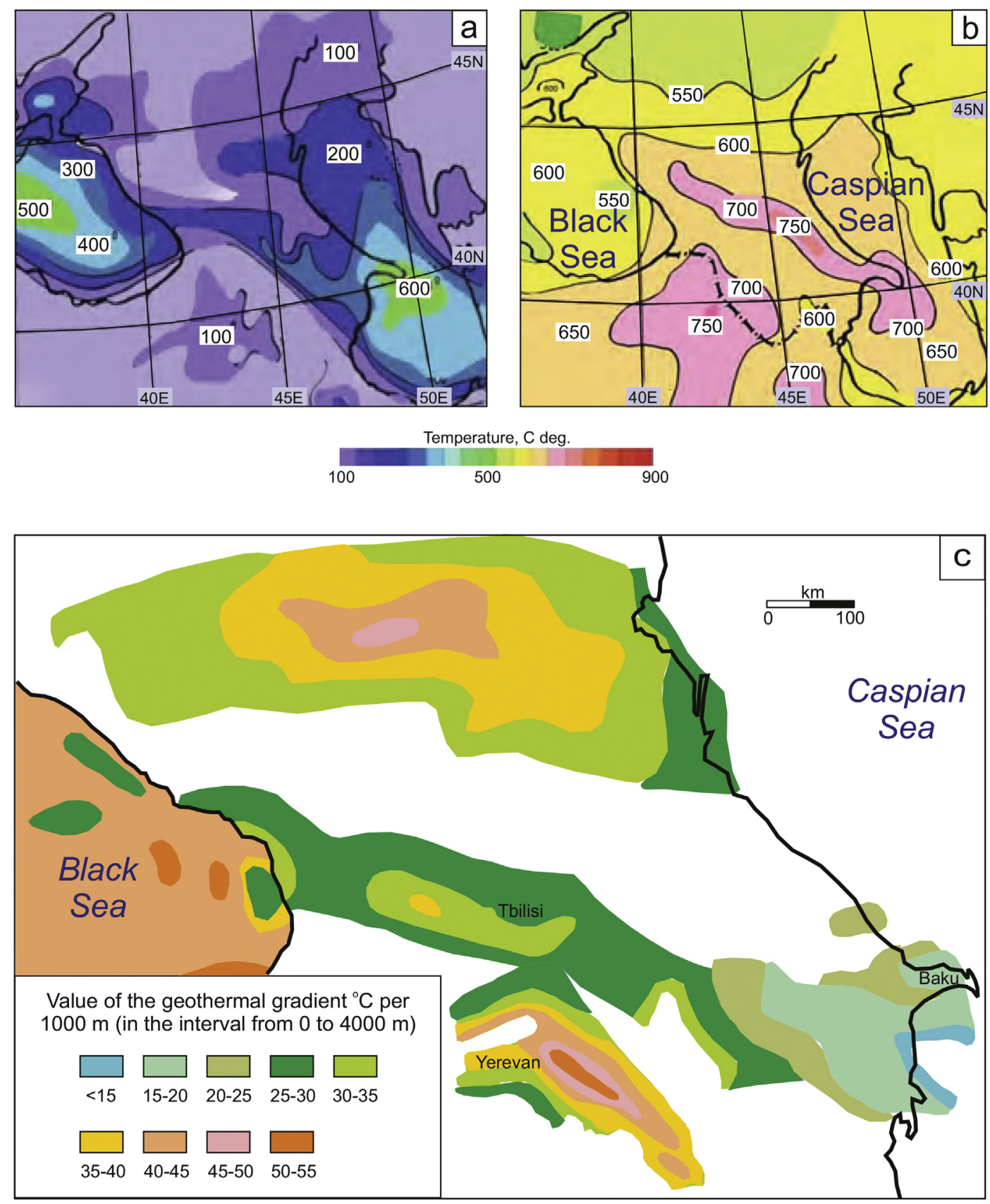

Fig. 4. Temperature and geothermal gradients in the Caucasus region. Temperatures (in ${ }^{\circ} \mathrm{C}$ ) at (a) the sedimentary basement and (b) the Moho depths derived from a geothermal modelling (Shengelaya, 1984; Alexidze et al., 1993), which account for sedimentation inferred from the paleo-reconstructions of the regional sedimentary cover by Sholpo (1978). (c) Geothermal gradients in the Caucasus from the depth of $4000 \mathrm{~m}$ (Kerimov et al., 1989); the Black Sea heat flow was obtained by measurements in the near-floor sediment layer (Kutas and Poort, 2008; Starostenko et al., 2014).

fill sediments. The most prominent north-directed thrust is the Dagestan foreland fold-and-thrust belt (Fig. 2a). From a structural point of view, although largely asymmetrical, the whole Greater Caucasus has a double vergence, with a pro- and retro-wedge actively propagating into the Kura foreland basin to the south and Kuban and Terek to the north (Mosar et al., 2010).

A Borjomi-Kazbegi fault (BKF; Fig. 5) was proposed as the western boundary of the actively indenting wedge (Philip et al., 1989; Rebai et al., 1993). According to these authors, the fault penetrates the entire crust as well as the Moho surface, and represents a left-lateral strike-slip fault, where its western block has been displaced about $90 \mathrm{~km}$ southwestward during the last 5.0-3.5 My (Philip et al., 1989), after the formation of the main structural units of the Caucasus, including the
Greater Caucasus, the Georgian block, and the Achara-Trialeti faultand-thrust belt. The fault slip rate has been estimated as $1.8-2.5 \mathrm{~cm} \mathrm{y}^{-1}$ (Philip et al., 1989). However, the near absence of significant earthquakes along the proposed BKF questions its existence (e.g., O'Connor et al., 2006). Also, local geologic and geomorphologic markers continue uninterrupted across the trace of the proposed fault (e.g., Martin et al., 2012).

The northward indentation of the Arabian block into the relatively mobile Caucasian-Middle Asia region guides the geometry of tectonic deformation, the seismicity and stress regime in the Black Sea-Caspian Sea area (Tsereteli et al., 2016). Three principal directions of active faults (Fig. 5) compatible with the dominant near N-S compressional stress produced by northward displacement of the Arabian plate can be 


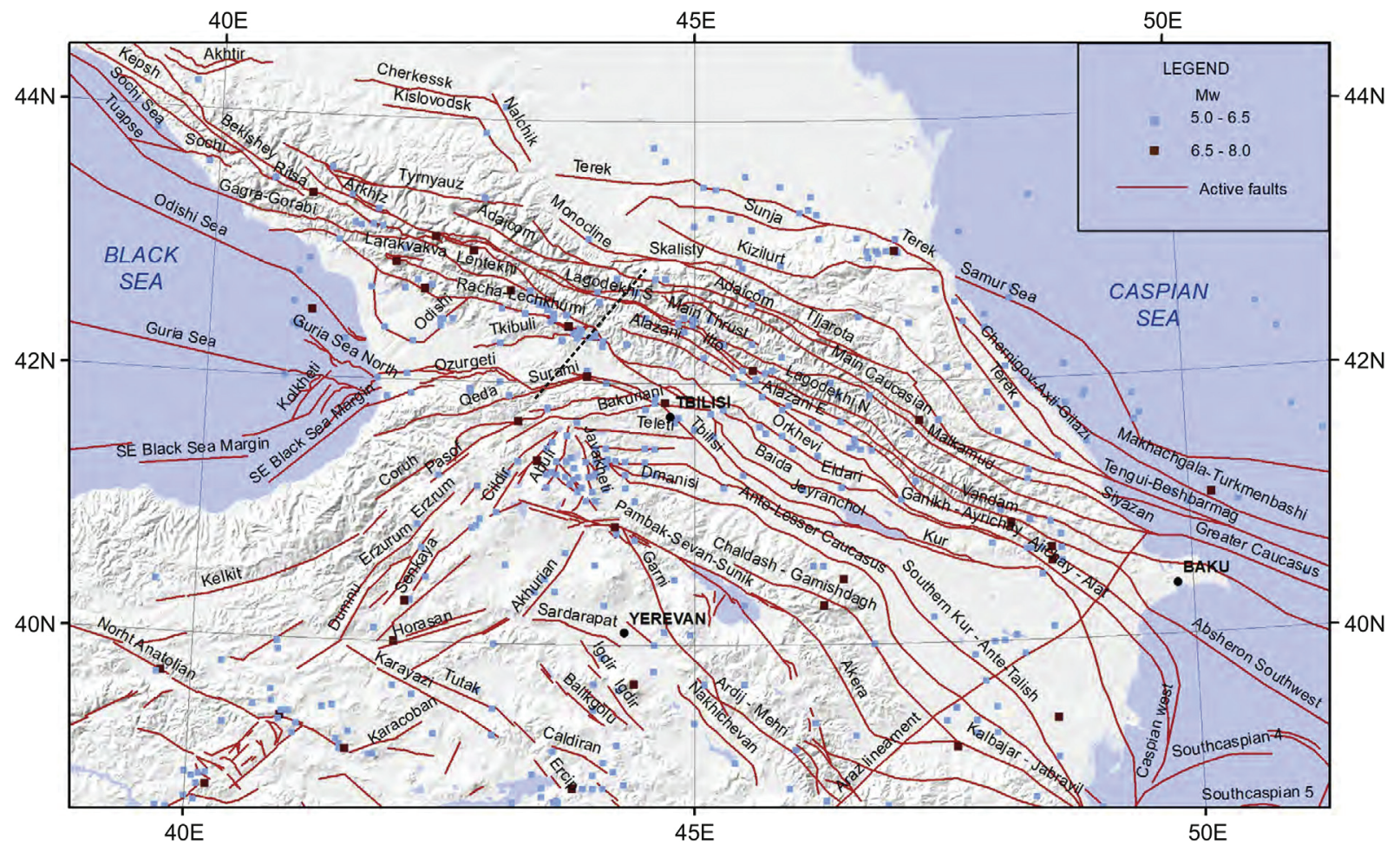

Fig. 5. Active faults and earthquake epicentres of the Caucasus and the surrounding area. The earthquake catalogue used covers the period from 50 A.D. to 2013 (Zare et al., 2014), and from 1855 to 2013 (Mumladze et al., 2015). Light blue squares mark the epicentres of earthquakes with moment magnitudes $5<M_{w} \leq 6.5$, and brown squared with $6.5<M_{w} \leq 8$. Active faults are compiled after Adamia et al., 2011, 2017; Danciu et al., 2018a; Karakhanyan et al., 2017. Dashed bold black line denotes the position of the proposed Borjomi-Kazbegi fault (Philip et al., 1989).

distinguished in the region. The majority of faults in the Kura basin and the Greater Caucasus trends WNW-ESE. In southwestern Georgia, a few faults trend E-W although there are ENE trending faults, which seem to extend southward to Turkey. The WNW-ESE trending structures consist mostly of reverse faults, thrusts, and thrust slices, which have some leftlateral strike-slip component. Other faults are interpreted to be compressional structures with a considerable right-lateral strike-slip component. The normal faulting is ascribed to Neogene-Quaternary volcanism in some areas of the Transcaucasus.

Contemporary tectonic stresses in the Caucasus region can be determined from focal mechanisms of crustal earthquakes, which indicate the maximum horizontal stress orientation and provide information on the relative stress magnitudes, i.e., tectonic regimes (Fig. 6; WSM, 2016). The overall stress regime of the Greater Caucasus is predominantly thrust faulting with a N-NE stress orientation in accordance with crustal shortening velocities. The central part of the Greater Caucasus exhibits also strike-slip tectonics, and normal faulting is observed in the eastern part of the Greater Caucasus. The western and central parts of the Lesser Caucasus exhibit all major types of the stress regime: thrust, normal and strike-slip faulting. Tectonic stresses induced by the northward motion of the Arabian plate are absorbed to a considerable degree in the Peri-Arabian ophiolitic suture zone and the Zagros fold-thrust belt. North of these structures the tectonic stresses are propagated towards the Central Caucasus by means of a relatively rigid block (Albino et al., 2014; Adamia et al., 2017a, 2017b; Sosson et al., 2017; Cavazza et al., 2017, 2018, 2019).

Dominant reverse earthquake focal mechanisms are linked to the frontal part of the Greater Caucasus, and strike-slip dominant mechanisms to its eastern termination. Sub-crustal earthquakes were recorded in the middle-southern Caspian Sea basin and the easternmost pre-Caucasus revealing a deep-seated zone of stress and strain localization (Allen et al., 2003; Kovachev et al., 2006; Mellors et al., 2012). The oceanic lithosphere of the southern Caspian Sea forms a rheologically resistant backstop around which the main morphological and tectonic structures bend. Since the Late-Middle Miocene, a new tectonic regime emerged, as the westward translation of Anatolia (e.g., McKenzie, 1972; Jackson and Ambraseys, 1997) is accommodating most of the Arabia-Eurasia convergence, thus precluding efficient northward stress transfer (Albino et al., 2014).

The shallow stress field, especially associated with the areas of hydrocarbon exploration and mud volcanism, is more complicated. For example, the easternmost part of the Greater Caucasus and the northern part of the central and south Caspian Sea basin show abundant mud volcanism with occasional explosive eruptions that cause oil and gas to burn on the earth surface (Bagirov and Lerche, 1997). According to Aliyev et al. (2002), about 200 marine and 180 continental mud volcanoes have been observed on an area of $60,000 \mathrm{~km}^{2}$ (Fig. 9). Mud volcanism and the associated mobilization of subsurface shale are strongly influenced by the state of tectonic stress. Although dynamic stresses produced by earthquakes are usually inferred to be the dominant triggering mechanism, static stress changes acting on the feeder systems of mud volcanoes may also play a role. Particularly, Bonini et al. (2016) showed that mud volcano eruptions in Azerbaijan within 2-10 fault lengths from the earthquake epicentre are favoured in the year following earthquakes, where the static stress changes cause compression of the mud source and unclamp feeder dikes.

A migration of earthquakes in a certain direction along major faults puzzles seismologists since the works by Mogi (1968). A stress perturbation and propagation after strong earthquakes may explain an earthquake migration in terms of the lithosphere deformation. IsmailZadeh (1996) analysed strong $(M>6)$ earthquakes in the eastern Caucasus and the western/central part of the Caspian Sea for 1930-1990, and showed the existence of the SE-migration of the seismic activity with a rate of $6 \mathrm{~km} \mathrm{y}^{-1}$. A model of tectonic stress propagation in the lithosphere explained the observed earthquake migration (Ismail-Zadeh, 1996). Coulomb stress changes dues to strong earthquakes in the Caucasus region (namely, the 1988 Spitak, the 1991 Racha, and the 2000 Caspian earthquakes; Table 1) showed an apparent 


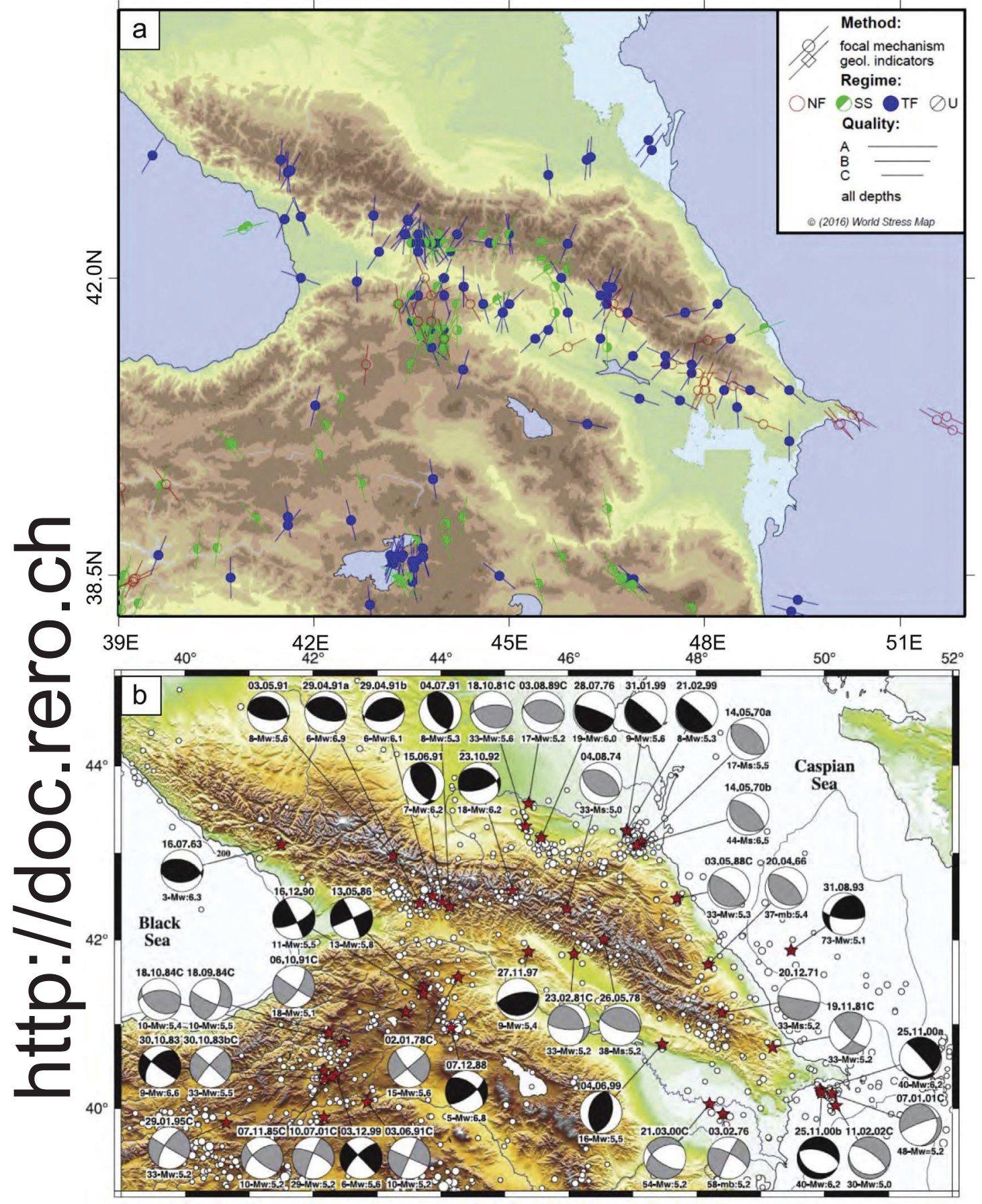

Fig. 6. Stress state of the Caucasus and its surroundings. (a) Compilation of stress indicators from the World Stress Map Project database using CASMO (http://www.world-stress-map.org/ casmo; WSM, 2016). (b) The fault plane solutions of the earthquakes in the Caucasus region studied by Tan and Taymaz (2006) (black) and by McKenzie (1972), Jackson and McKenzie (1984) (gray). The focal spheres are lower hemisphere equal area projections, with compressional quadrants shaded. Event dates (dd.mm.yy) are given on the top of the sphere, depth and magnitude at the bottom. The letter $C$ indicates the Harvard-Centroid Moment Tensor solution. The white circles represent epicenters of $\mathrm{M}>4$ earthquakes occurred during 1964-2001 (after Tan and Taymaz, 2006).

correlation between the mainshock stress changes and the spatial pattern of the aftershocks of the earthquakes (Ahadov and Jin, 2019).

\section{Gravity anomalies and density structure of the lithosphere}

Gravity data provide understanding of mass distribution and transport in the Earth system. Gravity surveys in the Caucasus region were mainly acquired in the former Soviet Union. Based on the data several models of gravity anomalies have been developed since mid1980s (e.g., Gorshkov and Niauri, 1984; Shengelaya, 1984; Gravity Map, 1990; Kadirov, 2000; Lodzhevsky and Kadirov, 2001; Kadirov, 2004; Kadirov and Gadirov, 2014). Fig. 7a presents a map of the Bouguer gravity anomalies in the Caucasus and the Caspian Sea region obtained by applying the Bouguer correction within the radius $200 \mathrm{~km}$ with the standard density for topography $2670 \mathrm{~kg} \mathrm{~m}^{-3}$ and $-1640 \mathrm{~kg} \mathrm{~m}^{-3}$ for bathymetry (Gravity Map, 1990; Kadirov, 2004). Furthermore, the upward continuation of the gravity field in the study area was calculated by Kadirov (2004) for the altitude $20 \mathrm{~km}$ using the Hartley transform (Hartley, 1942) (Fig. 7b). Several local minima are observed in the Absheron peninsula (Azerbaijan), between Makhachkala (Russia) and Sheki (Azerbaijan), near Tbilisi (Georgia), Yerevan (Armenia), and Tabriz (Iran). The south-eastern part of Azerbaijan (Talysh) is marked by the positive anomaly (up to $20 \mathrm{mGal}$ ) at the altitude $20 \mathrm{~km}$. At the same altitude, negative anomalies are observed along the Greater Caucasus, beyond the Lesser Caucasus toward Kars (Turkey) and Tabriz, and in the Absheron peninsula. Deep sub-vertical boundaries between structural units can be determined by computing horizontal gradients of the gravity field and marking their maximum. The shaded relief maps of 
Table 1

Strong $(\mathrm{M} 6+)$ earthquakes in the Caucasus and the surrounding region (1900-1970 earthquakes are from Kondorskaya and Shebalin, 1977; and for the period of 1973 to present from the USGS-ANSS Comprehensive Earthquake Catalogue; https://earthquake.usgs.gov).

\begin{tabular}{|c|c|c|c|c|}
\hline Place & Date & $\begin{array}{l}\text { Epicentre (lat. N, } \\
\text { lon. E) }\end{array}$ & Magnitude $^{a}$ & $\begin{array}{l}\text { Focal } \\
\text { Depth } \\
(\mathrm{km})\end{array}$ \\
\hline $\begin{array}{l}\text { Shamakha } \\
\text { (Azerbaijan) }\end{array}$ & 13.02 .1902 & $40.7,48.6$ & $6.9 \pm 0.2$ & 15 \\
\hline Teberda (Russia) & 21.10 .1905 & $43.3,41.7$ & $6.4 \pm 0.1$ & 60 \\
\hline Kartli (Georgia) & 20.02 .1920 & $42.0,44.1$ & $6.2 \pm 0.3$ & 11 \\
\hline Erzurum (Turkey) & 13.09 .1924 & $40.0,42.0$ & $6.9 \pm 0.1$ & 15 \\
\hline Zangezur (Armenia) & 27.04 .1931 & $39.2,46.0$ & $6.3 \pm 0.1$ & 22 \\
\hline Caspian & 20.10 .1931 & $42.5,50.8$ & $6.2 \pm 0.5$ & 70 \\
\hline Caspian & 09.04.1935 & $42.1,48.8$ & $6.3 \pm 0.5$ & 90 \\
\hline Digor (Turkey) & 01.05 .1935 & $40.4,43.4$ & $6.2 \pm 0.1$ & 14 \\
\hline Tabatskuri (Georgia) & 07.05 .1940 & $41.7,43.8$ & $6.0 \pm 0.2$ & 19 \\
\hline $\begin{array}{l}\text { Zakataly } \\
\quad \text { (Azerbaijan) }\end{array}$ & 29.06 .1948 & $41.6,46.4$ & $6.1 \pm 0.2$ & 48 \\
\hline Caspian & 18.09.1961 & $41.06,50.23$ & $6.6 \pm 0.5$ & 64 \\
\hline Caspian & 27.01.1963 & $41.08,49.84$ & $6.2 \pm 0.1$ & 55 \\
\hline Chkhalta (Georgia) & 16.07.1963 & $43.25,41.58$ & $6.4 \pm 0.2$ & 5 \\
\hline Dagestan (Russia) & 14.05 .1970 & $43.00,47.09$ & $6.6 \pm 0.2$ & 44 \\
\hline $\begin{array}{l}\text { Urus-Martan } \\
\text { (Russia) }\end{array}$ & 28.07.1976 & $43.172,45.603$ & 6.2 & 28 \\
\hline Turkey-Iran border & 24.11.1976 & $39.121,44.029$ & 7.5 & 36 \\
\hline Caspian & 04.05 .1980 & $38.053,48.985$ & 6.2 & 30 \\
\hline Narmar (Turkey) & 30.10 .1983 & $40.330,42.187$ & 6.8 & 15 \\
\hline Spitak (Armenia) & 07.12 .1988 & $40.987,44.185$ & 6.9 & 5 \\
\hline Racha (Georgia) & 29.04.1991 & $42.453,43.673$ & 7.0 & 17 \\
\hline Sakartvelo (Georgia) & 23.10 .1992 & $42.589,45.104$ & 6.4 & 30 \\
\hline Ardabil (Iran) & 28.02.1997 & $38.075,48.050$ & 6.1 & 33 \\
\hline Lerik (Azerbaijan) & 09.07.1998 & $38.717,48.507$ & 6.0 & 26 \\
\hline Caspian & 25.11 .2000 & $40.245,49.946$ & 6.8 & 50 \\
\hline Sakartvelo (Georgia) & 07.09.2009 & $42.660,43.443$ & 6.0 & 15 \\
\hline Van (Turkey) & 23.10 .2011 & $38.721,43.508$ & 7.1 & 18 \\
\hline
\end{tabular}

a The magnitude of historical earthquakes in the Caucasus was calculated from the intensity of the earthquakes for the period of non-instrumental observations; for earthquakes of $M>5$, the magnitude was redetermined for the whole period of instrumental observations using seismograms. The magnitudes reported in the USGS-ANSS Comprehensive Earthquake Catalogue (since 1971) were the best estimates of the size of the earthquakes available at the time of catalogue's development.

the horizontal gradients of the gravity field in the Caucasus-Caspian region at various altitudes (Fig. 7c, d; Kadirov, 2004) show that major faults in the region are associated with the regional gravity anomalies (e.g., Borisov, 1967; Shikhalibeili, 1996). Also, the maximum horizontal gravity gradients are correlated with morphostructural patterns (Gorshkov and Niauri, 1984; Gorshkov et al., 2003; Soloviev and Gorshkov, 2017).

Analysis of the gravity anomalies can help in understanding tectonic processes in the Caucasus. However, the interpretation is complicated because of non-uniqueness of gravity inversions. To overcome this difficulty, gravity data are analysed together with other geophysical information, for instance, seismic data (e.g., Kaban et al., 2016). The residual mantle gravity anomalies and residual topography in the Caucasus and the surrounding regions have been determined by removing crustal (Kaban et al., 2016) and lower mantle (Kaban et al., 2015) effects. The residual gravity anomalies vary from about -150 $\mathrm{mGal}$ to more than $400 \mathrm{mGal}$ in the region (Fig. 8a), which range substantially exceeds possible uncertainties (Kaban et al., 2016). The most pronounced gravity minima (maxima for the residual topography) in the study area correspond to the Lesser Caucasus confirming that the area is characterized by the hot and lower dense upper mantle (Fig. 8a, b). The Greater Caucasus splits the denser upper mantle block associated with the Scythian plate in the north and the predominantly lower density upper mantle block in the south. The strongest positive mantle gravity anomalies and the lowest residual topography are located over the Zagros fold belt and South Caspian (Fig. 8a, b). The residual gravity and topography were jointly inverted to obtain a three-dimensional density model of the upper mantle (Kaban et al., 2015, 2016). The inversion was constrained by the initial density model based on seismic tomography imaging (Schaeffer and Lebedev, 2013). The density model demonstrates that the denser Scythian plate is overlain by the northernmost part of the Arabian plate and the Caucasian lithosphere, and hints at possible overthrust of the Arabian-Caucasian lithosphere or underthrust of the Scythian plate under the western Greater Caucasus (Fig. 8c; Kaban et al., 2018). A V-shaped density anomaly under the Arabia-Eurasia collision zone suggests two oppositely directed sinking lithospheric slabs: under the Zagros fold belt to the north and under the eastern Greater Caucasus to the south (Fig. 8d). Deep seismicity under the northern part of the eastern Great Caucasus corresponds to the contact of the slabs (Kaban et al., 2018).

\section{Geodetic observations and lithosphere deformation}

During about two decades monitoring crustal deformation in the Caucasus coordinated and integrated with geodetic studies in neighbouring parts of the AR-EU collision zone provide constraints on the geodynamic processes that are actively deforming the collision zone (e.g., McClusky et al., 2000; Reilinger et al., 2006; Kadirov et al., 2008, 2012; Forte et al., 2012; Karakhanyan et al., 2013; Ahadov and Jin, 2017; Sokhadze et al., 2018). These geodynamic processes produced and maintain the high elevation of the Caucasus and are the cause of the earthquake activity in the region. GPS velocities in the zone of interaction of the African, Arabian, and Eurasian plates have been used to estimate how AR-EU convergence is partitioned between lateral "extrusion" of crustal blocks and crustal shortening. It was found that a large majority $(\sim 70 \%)$ of the convergence is accommodated by lateral transport and $\sim 15 \%$ by shortening along the seismically active GCFTB with the remainder being accommodated by other structures or distributed strain. The thickened crust in the Lesser Caucasus-Eastern Turkey Plateau (e.g., Gök et al., 2003; Barazangi et al., 2006) and 150-400 km of continental convergence (McQuarrie and van Hinsbergen, 2013) indicate that the geodetic results reflect long-term tectonic deformation processes in the collision zone.

Fig. 9 shows the GPS velocity field in the Caucasus region providing a quantitative basis to estimate the locations, slip rates, and directions of the major structures that accommodate deformation. The present shortening in the Arabia-Eurasia collision zone occurs mainly south of the Main Caucasus Thrust, which is the meridional limit to the basement massifs in the central and western region and which runs through the core of the orogeny to the east; this shortening correlates with the highest uplift in the centre of the orogeny (Mosar et al., 2010; and references therein). The velocity field derived from GPS observations clearly demonstrates the NNE crustal surface motions in the Lesser Caucasus and Azerbaijan relative to Eurasia. The velocity field shows a velocity decrease eastward orthogonally to the GCFTB. The NNE motion of the Earth's surface is interpreted as one of the factors responsible for the accumulation of stresses on the Main Caucasus Thrust. Apart of this, there is a trend of horizontal displacement within the Kura basin and the Lesser Caucasus, where the velocity increases from the west to the east along the strike of the mountain chain. This is well illustrated in the series of velocity profiles in Fig. 9 (b-f), which show the rate of motion versus distance along profiles parallel to and traversing the Caucasus system (profile locations on Fig. 9a). The plot in Fig. 9b for the profile aligned along strike of the Greater Caucasus demonstrates the progressive increase in convergence rate with Eurasia from west to east, from 1 to $2 \mathrm{~mm} \mathrm{y}^{-1}$ near the eastern end of the Black Sea, to 13-14 $\mathrm{mm} \mathrm{y}^{-1}$ south of Baku, Azerbaijan. The absence of any consistent change in rates in the direction of the profile traversing the Lesser Caucasus (i.e., Fig. 9 c, e, f) constrains active shortening in the Lesser Caucasus to less than $2 \mathrm{~mm} \mathrm{y}^{-1}$. These observations, and the low level of significant seismicity in the Lesser Caucasus (the 1988 Spitak 

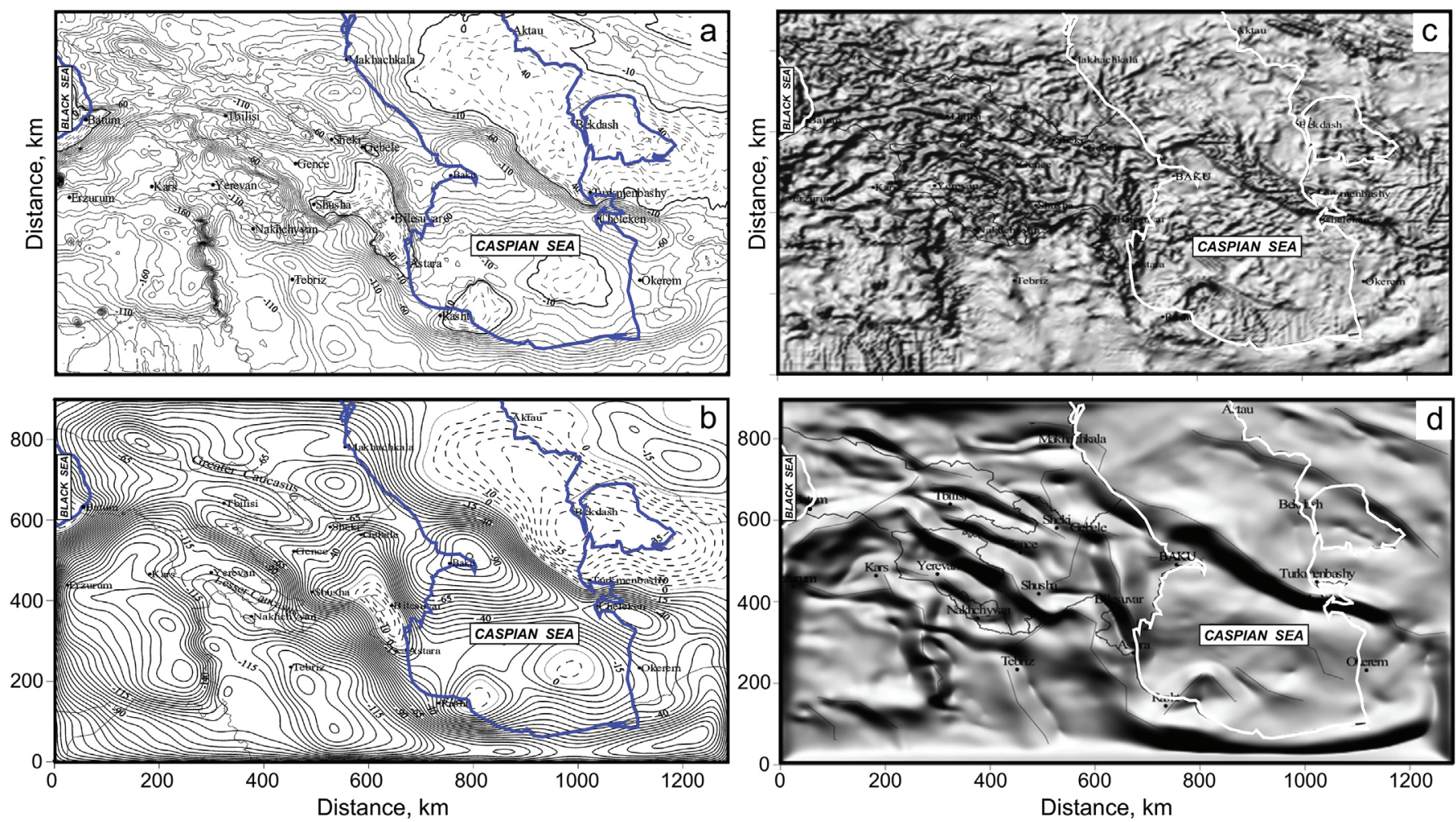

Fig. 7. Gravity maps for the Caucasian-Caspian region. Left panel. Bouguer gravity anomalies: the original data (a), and the filtered data for the altitudes of 20 km (b). Negative and positive anomalies are marked by continuous and dotted lines, respectively. Right panel. Shaded Relief Map of horizontal gradients of the gravity field: original data (c; the angles of the horizontal and vertical light position are $135^{\circ}$ and $45^{\circ}$, respectively), and the filtered data for the altitudes of $20 \mathrm{~km}$ (d; the angles are $45^{\circ}$ and $45^{\circ}$ ).

U

earthquake being a notable exception), suggest that within the resolution of the GPS observations, the Lesser Caucasus behaves like a coherent block rotating in a counter clockwise sense with respect to Eurasia, around a pole near the eastern end of the Black Sea (e.g. Lawrence, 2003; Copley and Jackson, 2006; Reilinger et al., 2006).

The nature of the eastern GCFTB remains an outstanding question in the tectonics of the Caucasus with implications for earthquake hazards in the greater Baku region (Kadirov et al., 2012). Specifically, the physical connection (i.e., faults or zones of deformation) between the GCFTB and the Central Caspian Seismic Zone (CCSZ) remains uncertain. Although both structures accommodate convergence with Eurasia, the style of the deformations is different in the two zones. Lower crustal $(\sim 40 \mathrm{~km})$ earthquakes occur along the CCSZ with focal mechanisms indicative of deformation within the subducting plate rather than at the plate interface (Jackson et al., 2002). Meanwhile, shallow crustal $(\sim 15-20 \mathrm{~km})$ thrust events occur at the GCFTB (e.g., Triep et al., 1995). The deformation style might be influenced by the different rheological behaviors between the continental lithosphere of the Kura basin and the oceanic lithosphere (with thick and consolidated sediments) of the South Caspian basin (Knapp et al., 2004; Kadirov and Gadirov, 2014). Also, the different modes of accommodating shortening at the plate interface reflect different dynamics - subduction in the CCSZ and continental collision along the GCFTB (e.g., Copley and Jackson, 2006; Reilinger et al., 2006; Vernant and Chery, 2006). Moreover, recent geodetic observations in the southern edge of the Caspian Basin in Iran (Djamour et al., 2010) and in Azerbaijan (Kadirov and Gadirov, 2014) show that a branch (or multiple branches) of the GCFTB may follow the curved topographic break between the Kura basin and the Greater Caucasus, and the structures accommodating deformation may merge offshore with the thick, folded sediments south of the Absheron Peninsula. If this is the case, the crustal shortening accommodated by the GCFTB is partitioned between NE-SW shortening across the Absheron Peninsula and right-lateral, transpressive deformation south of Baku that joins the system of folded sediments in the SW Caspian Basin.

To analyse the surface displacement based on two possible continuations of the GCFTB, Kadyrov et al. (2012) developed two models of surface deformation for the eastern Greater Caucasus based on the analytical expressions for the surface displacements and strains (Okada, 1985). Both models include thrusting along the segment of the GCFTB west of the Absheron Peninsula, where on average the fault dips northward at $30^{\circ}$. One model extends to the east, south of Baku, connecting with the Central Caspian Seismic Zone, and another model has the fault following the topographic break of the GCFTB west of Baku, turning to the south and extending through the Neftchala Peninsula. The modelled velocities are illustrated in Fig. 9 for the relevant profiles (c-e). Results of both models along profiles CC' and DD' (Fig. 9d, e) fit well the geodetic observations, but the model results along profile BB' (Fig. 9c) fail to explain the GPS velocities. More realistic models will require better geodetic constraints on the spatial distribution of motions around the eastern segment of the GCFTB. The geodetic measurements using additional stations installed in the Azerbaijan network (Aktuğ et al., 2013) substantiate the activity of the Caspian West fault, which is likely to be a continuation of the GCFTB south of the Caspian Sea. Kadirov et al. (2008) assessed a right-lateral slip rate of $11 \pm 1 \mathrm{~mm} \mathrm{y}^{-1}$ for the Caspian West fault and asserted that this fault is predominantly a strike-slip fault. Aktuğ et al. (2013) showed that the fault accommodates right-lateral slip of $7.1 \pm 0.3 \mathrm{~mm} \mathrm{y}^{-1}$ in addition to $5.5 \pm 0.3 \mathrm{~mm} \mathrm{y}^{-1}$ contraction.

Based on the integration of new and previous GPS studies, Karakhanyan et al. (2013) concluded that the Kura basin and the Lesser Caucasus are likely to be different blocks, and that the Pambak-Sevan-Sunik fault (see Fig. 5) between these two blocks has a right-lateral slip rate of $2 \pm 1 \mathrm{~mm} \mathrm{y}^{-1}$. The Sardarapat and Akhurian faults (Fig. 5) experience shortening of about $1 \mathrm{~mm} \mathrm{y}^{-1}$, which is consistent with the uplift inferred from archaeological data (Karakhanyan et al., 2004; 

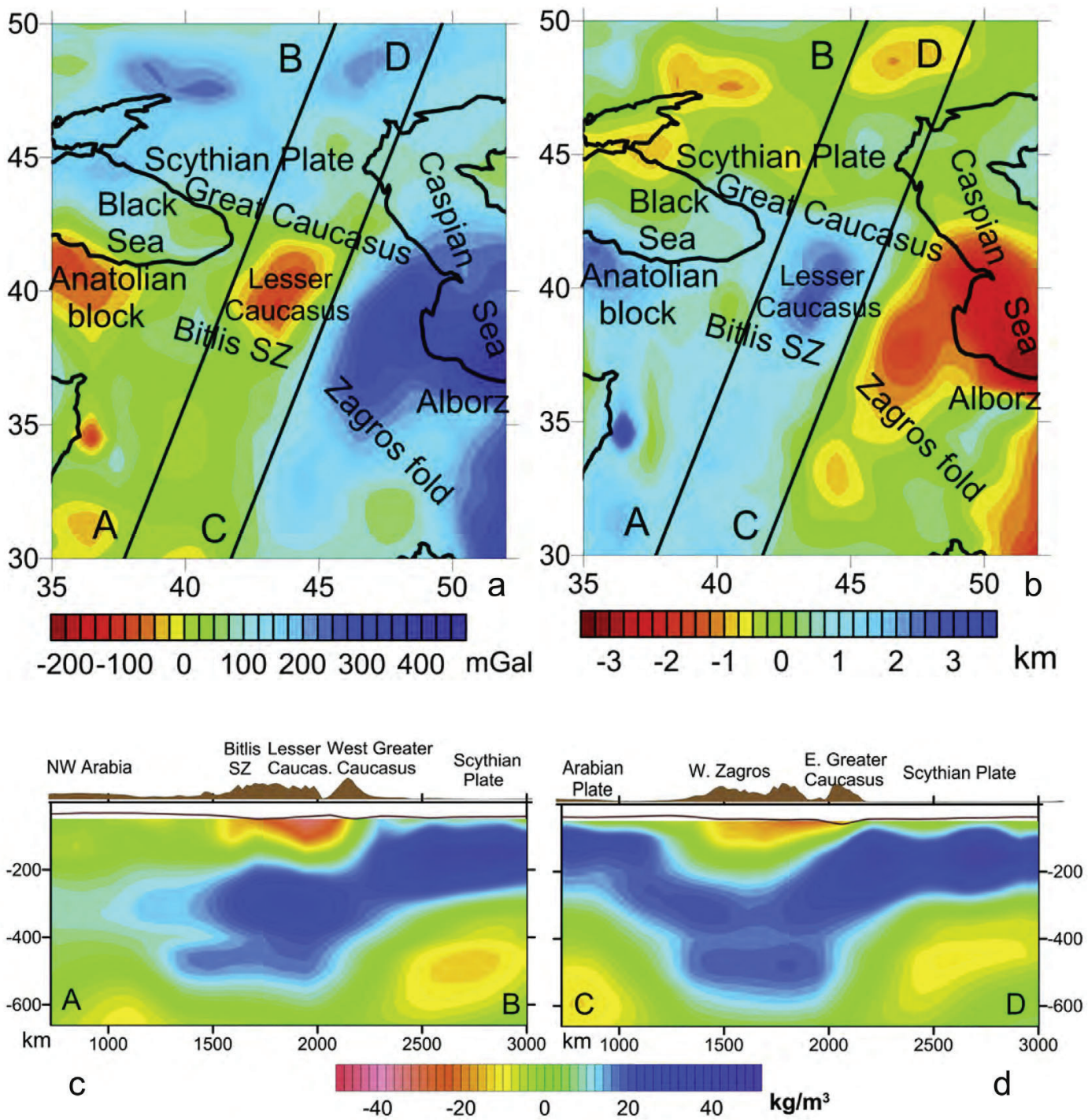

Fig. 8. Residual mantle gravity anomalies (a) and residual topography (b) induced by density variations in the upper mantle beneath the Caucasus and the surrounding region (Kaban et al., 2016, 2018). Black lines show the positions of two profiles illustrating the density model: profile AB (c) and profile CD (d).

2013). However, NNW-SSE-orientated faults have an extensional fault normal component instead of the expected shortening due to the Arabia-Eurasia convergence. This extensive strain and the sharp azimuth change of the velocity vectors between the Arabia promontory and the Lesser Caucasus suggest that the Arabian plate push may not be the sole geodynamic force in the region and processes related to subduction or delamination may also contribute to the regional geodynamics (Karakhanyan et al., 2013).

Site motions derived from GPS observations (2008-2016) in Georgia allowed constraining the rate and locus of active shortening in the Lesser-Greater Caucasus along two nearly N-S-oriented profiles, one crossing the Rioni Basin and another crossing the area near the longitude of Tbilisi (Sokhadze et al., 2018). Using elastic fault modelling, the authors showed that convergence occurs along the southern margin of the Greater Caucasus, in agreement with strain accumulation on the fault that generated the 1991 Racha earthquake. Meanwhile, convergence near Tbilisi and the adjacent northern boundary of the Lesser Caucasus suggests that this convergence is related to the incipient collision of the Lesser and Greater Caucasus.

\section{Seismicity and seismic models of the crust and the mantle}

The Caucasus is a moderate to strong earthquake-prone region
(Fig. 5), where devastating earthquakes caused significant losses of lives and livelihood and damaged infrastructure. One of the first recorded strong earthquake of magnitude M6.6 \pm 0.7 occurred in the southwestern flank of the Greater Caucasus mountains (near the eastern coast of the Black Sea) in about 550 BC destroying the town of Dioskuria (Kondorskaya and Shebalin, 1977). The 1139 Ganja (Azerbaijan) M6.8 \pm 0.7 earthquake resulted in 200,000-300,000 death toll. Due to this earthquake a part of the Kapaz Mount collapsed and blocked the Kürakçay river creating Lake Göygöl. Another significant event occurred in 1350 (M6.5 \pm 0.7 earthquake) in the Chegem gorge (Russia) causing huge landslides, which buried many settlements (Kondorskaya and Shebalin, 1977). Devastating earthquakes hit the city of Shamakha (Azerbaijan) several times since the middle 17th century. The 1667 M6.9 \pm 0.7 earthquake killed about 80,000 inhabitants, and its 1669 powerful M6.0 \pm 0.7 aftershock other 6000 to 7000 people. A less powerful $($ M5.9 \pm 0.5$)$ earthquake in 1859 was so destructive that the Governor's seat and governmental institutions were transferred from Shamakha to Baku. In 1872, another M5.7 \pm 0.5 shock occurred triggering emigration of people to Baku, where industrial production of oil had started (The New York Times, 1902a). The last devastating M6.9 \pm 0.2 earthquake in Shamakha occurred on 13 February 1902. 34 villages surrounding Shamakha suffered the earthquake, about 2000 people (about $10 \%$ of the total population of the city) were perished, 

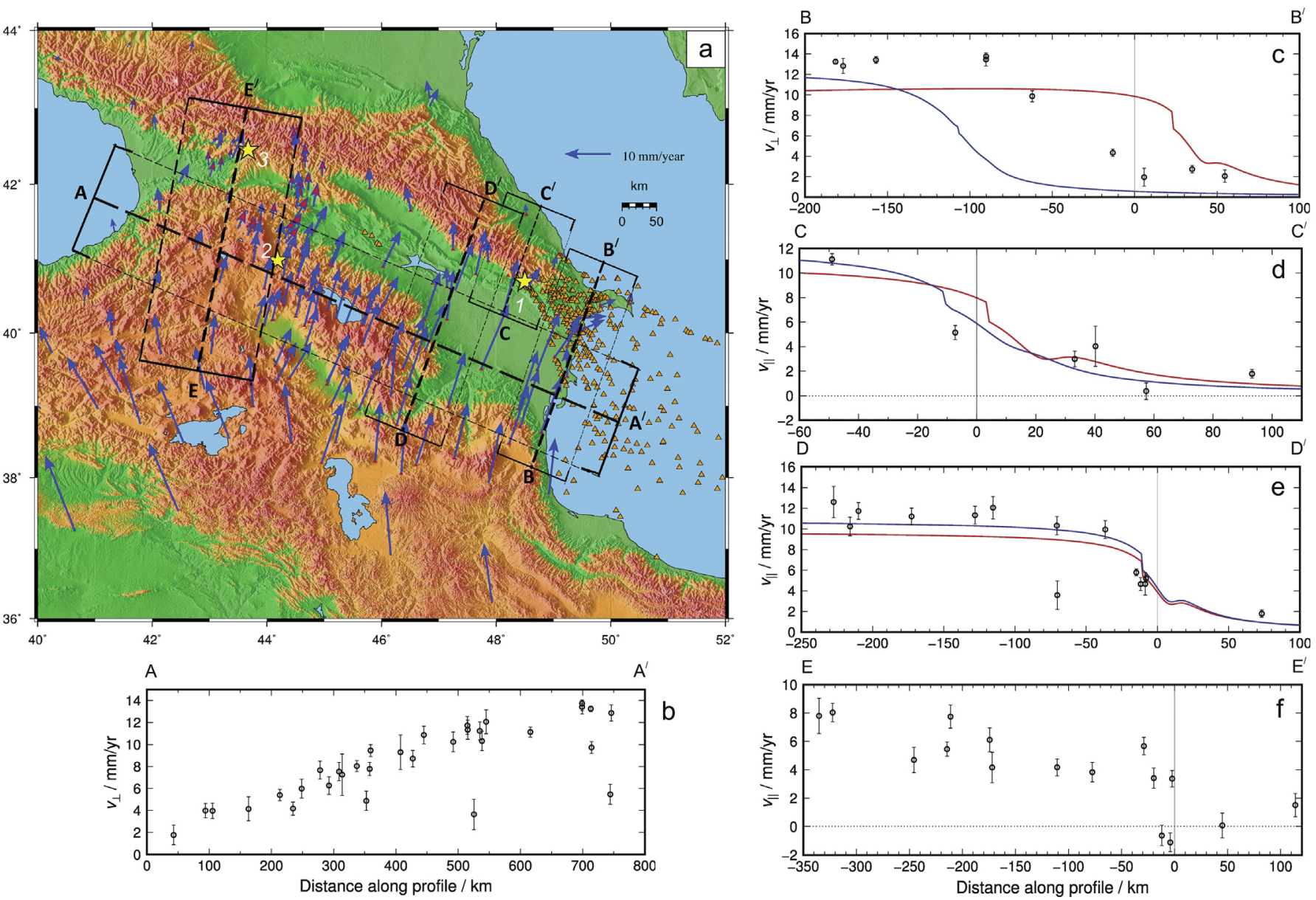

Fig. 9. GPS velocities measured in the Caucasus. (a) Map of the velocities with respect to Eurasia for the eastern AR-EU collision zone. Blue arrows are the velocities from Kadyrov et al. $(2012,2015)$, and blue arrows with red heads are the velocities from Sokhadze et al. (2018). Yellow stars show the epicentres of the 1902 Shemakha (1), the 1988 Spitak (2), and the 1991 Racha (3) earthquakes. Orange triangles represent mud volcanoes. Velocity profiles AA'-EE' are shown in panel (b)(f). Plots of transverse (AA') and parallel (BB'-EE') components of velocities versus distance along the profiles shown in the map. Red and blue curves (in c-e) are the modelled velocity profiles (from Kadyrov et al., 2012).

and 4000 houses were destroyed. A mud volcano erupted with immense flames and lava flows near Shamakha adding to the disaster due to the earthquake (The New York Times, 1902b). Historical data are important for understanding earthquake occurrences, but the information on historical earthquakes is limited and insufficient to analyse a particular event in some detail. For example, isoseismals are usually incomplete, and the number of observed localities is limited. This results in an inaccuracy of assessment of earthquakes parameters, such as depth and intensity damping.

Instrumental observations of earthquakes in the Caucasus began after the destructive 1902 Shamakha earthquakes when the first seismographs and pendulum were installed in the Caucasus region and in a few towns of Russia (e.g., Veber, 1904). These instruments did not contribute to detailed information about the regional seismic activity because of their low magnification degree. In 1911-1912 the Golitsyntype seismographs were installed in Baku and Tbilisi; both stations were closed at the beginning of the World War I, and restarted their activity in the 1920s. These stations were re-equipped in 1931 with more sensitive apparatus that provided recording of events with magnitude $\mathrm{M}=4.5$, and with Kirnos-Kharin type seismographs installed after World War II the events with magnitude 4.0 could be recorded (Panahi, 2006). According to the same source, since 1955 the network was expanded in the Caucasus (26 stations, in total), and the quality of recording was improved due to modern electromagnetic seismographs installed in the region. In early 1970th another generation of large aperture instruments were introduced, and the number of seismic station in the Caucasus was increased to thirty. Since 2003 the new digital real-time seismic network consisting of several dozen satellitebased monitoring stations started operation in Azerbaijan (Panahi, 2006) allowing for low magnitude events $(M=2.0)$ to be recorded in some areas of Azerbaijan and increasing the accuracy of earthquake location up to $\pm 5 \mathrm{~km}$ in some places.

Seismic network resolution in the Caucasus has improved in the last several years. National networks deployed new seismic stations and established good collaboration in exchanging online waveform data. In 2017 Armenia, Azerbaijan, Georgia and USA started a new project related to the uplift and seismicity of the Greater Caucasus and jointly deployed fifty-three seismic stations in the region (Godoladze et al., 2018). The use of seismic data from over hundred new stations in Azerbaijan, Armenia, Russia, and Georgia will allow for better understanding of the deep structure of the Greater Caucasus.

Strong earthquakes of magnitude 6.0 and greater occurred in the region from 1900 to present (Table 1). Two devastating earthquakes occurred in the region during last several decades: the 7 December 1988 Mw6.9 Spitak (Armenia) earthquake, and the 29 April 1991 Mw7.0 Racha (Georgia) earthquake (where Mw is the moment magnitude). The Spitak earthquake caused immense human casualties (about 25,000 people were killed), the city of Spitak and Leninakan (now Gyumri) were destroyed to $90 \%$ and $50 \%$, respectively (Cisternas et al., 1989). The Racha earthquake, the strongest event ever recorded in Georgia, took about 100 human lives and caused significant destruction within densely populated areas (Adamia et al., 2017). 


\subsection{Sub-crustal seismicity}

The hypocentral depths of earthquakes in the Caucasus vary in response to the geodynamic processes in the region. Most remarkable are sub-crustal earthquakes under the northern foothills of the Greater Caucasus for which different explanations were proposed. One of the hypotheses is that the earthquakes are associated with the oceanic slab sinking beneath the Greater Caucasus (e.g., Tskhakaya, 1962; Khalilov et al., 1987; Godzikovskaya and Reysner, 1989; Khain and Lobkovsky, 1994; Kovachev et al., 2006). Short-term bottom seismic observations in the Yalam-Samur area at northeastern foot of the Greater Caucasus revealed a deep-seated compact zone of mantle-earthquake sources (Kovachev et al., 2006) Based on the analysis of data from local and regional networks, teleseismic depth phases, and examination of waveforms, Mellors et al. (2012) suggested the presence of a remnant northeast-dipping subduction of oceanic crust with the interface at the northern edge of the Kura basin under the Greater Caucasus. New compilation of local earthquake hypocentres yields evidence of a northdipping subducted slab beneath the eastern Greater Caucasus extending to $100-160 \mathrm{~km}$ depth (Mumladze et al., 2015).

\subsection{Regional seismicity}

Based on the study of the discrepancies in seismic P- and S-wave velocity path lengths, the inhomogeneities of the internal structure of the crust and the uppermost mantle of the Lesser Caucasus and the Armenian Highlands were determined and mapped (Karapetyan, 1973; Saakyan et al., 1983). Using analysis of the dispersion of seismic surface wave group velocities due to strong earthquakes Karapetyan (1986) determined the crustal thickness as well as the thickness of individual layers within the crust in Armenia and adjacent areas. The spatiotemporal distribution of strong earthquakes within Armenia was studied by Geodekyan and Sargsyan (1987), and the long-term average quantitative characteristics of seismicity level and their frequency were determined. Although the simplified model of the seismic regime derived in this study could identify the areas of potential strong earthquakes of $M \sim 6$, including the city of Spitak, this model could not recognize Spitak as a zone of potential earthquakes of $M \sim 7$. The 7 December 1988 M6.9 earthquake in Spitak led to a disaster. The epicentre of this destructive event was located within the Lesser Caucasus subjected to north-south compression by the push of the Arabian plate. A field expedition immediately after the earthquake revealed the fault scarp of $13 \mathrm{~km}$ long with a reverse dislocation of $1.6 \mathrm{~m}$. Aftershocks were shallower than $13 \mathrm{~km}$, and delimited a ruptured surface of about $300 \mathrm{~km}^{2}$ (Cisternas et al., 1989).

Seismicity in Azerbaijan and the adjacent Caspian Sea region is moderate with recorded earthquake magnitudes to be less than 7 , although seismic events of greater magnitude $(M>7)$ can occur in the region (Ahmedbeyli et al., 1991). The majority of shallow small-magnitude earthquakes occur at faults within structural blocks (Guliyev and Panahi, 2004; Panahi, 2006). Particularly, in the Balakend-Zagatal earthquake-prone zone of Azerbaijan, the processes leading to earthquakes in this zone are likely to be internal and not directly linked to the deformation and tectonic movements of main structural elements of the Caucasus region (Ismail-Zadeh, 2006). Sources of strong earthquakes in the eastern Caucasus and the Caspian Sea region are located in the crust at the depths of 10 to $40 \mathrm{~km}$. The sources of many crustal earthquakes in the southeastern part of the Greater Caucasus and the Kura basin are likely to be associated with volcanogenic-sedimentary and terrigenous-carbonate Mesozoic formations (Agamirzoyev, 1987). The hypocentres of earthquakes in the Kura basin are concentrated at depths of 9-13 km and 21-25 km (Panahi, 2006). A heterogeneity in the depth distribution of low magnitude (2.5-3.3) earthquakes in the eastern Greater Caucasus was explained by morphological complexity of folding in the region (Rogozhin et al., 1993).

The strongest ( $\mathrm{Mw}$ 7.0) recorded seismic event in Georgia occurred in the province of Racha on 29 April 1991. Its epicentre was located in the Southern slope zone of the Greater Caucasus (Triep et al., 1995; Fuenzalida et al., 1997). The main shock was followed by numerous aftershocks, which lasted for several months, and the largest aftershock was Ms. $=6.2$ on 15 June 1991 causing additional damage. The focal mechanisms of more than fifty $\mathrm{M}>4$ aftershocks were studied (e.g., Tan and Taymaz, 2006; Tseng et al., 2016; see also Fig. 6b). Most of them show that nodal planes were orientated to WNW or NW. All the shocks were shallow: the focal depths varied from 2 to $32 \mathrm{~km}$ with the majority in the range of 10 to $22 \mathrm{~km}$, and the focal depth of the mainshock was $6 \mathrm{~km}$. The epicentre region represents a boundary zone between two main tectonic units: the Greater Caucasus fold-thrust mountain belt in the north, and the rigid Georgian block in the south (Figs. 2b; 5). The northern periphery of the Georgian block is dissected by a system of active W-E- and NW-SE-trending faults, which are grouped in two clusters of thrusts and reverse faults. The overwhelming majority of strong shocks (including the main shock) were associated with the southern branches of these seismically active structures (Mosar et al., 2010; Adamia et al., 2017).

The North Caucasus is characterized by the highest seismic activity in European Russia. The identification of potential earthquake sources in the North Caucasus is of importance for seismic hazard assessment in this densely populated region (Ulomov et al., 2007). The eastern part of North Caucasus (Daghestan, Chechnya, Ingushetia, and North Ossetia) is prone to earthquakes, with strong seismic events in $1830(\mathrm{Ms}=6.3$ ) and 1970 (Ms = 6.6) in Daghestan, in 1976 (Ms = 6.2) in Chechnya, and in 1905 (Ms = 6.4) in Teberda. These earthquakes were felt in Russia with an intensity of up to 5-6. The local seismicity of the Scythian plate adjacent to the North Caucasus is associated with the Stavropol uplift partially encompassing Adygeya, the Stavropol and Krasnodar regions. The strongest event (Ms $=6.0)$ occurred in 1879 in the Lower Kuban area (Kondorskaya and Shebalin, 1977). Historical records yield evidence for a catastrophic Pontic earthquake (63 B.C.) that destroyed a number of towns on both sides of the Kerch Strait. Several strong earthquakes occurred near Anapa, Novorossisk, and Sochi, as well as in other zones of the Black Sea coast (Ulomov et al., 2007).

\subsection{Seismic models of the crust and the sub-crust}

Deep seismic sounding profiles Stepnoye-Bakuriani and VolgogradNakhchivan provided significant knowledge about the crustral structure of the Caucasus. Particularly, interpretation (Yurov, 1963; Krasnopevtseva et al., 1970) and reinterpretation (Eppelbaum and Khesin, 2011; Pavlenkova, 2012; Ghonghadze et al., 2016) of the profiles showed that the thickness of the crust beneath the western Greater Caucasus increases up $60 \mathrm{~km}$ and beneath the eastern Greater Caucasus up to $70 \mathrm{~km}$.

A three-dimensional seismic model of the Caucasus crust constrained by the gravity field was developed based on deep seismic sounding of the regional lithosphere, seismic refraction and reflection profiling, surface wave velocities, large explosions, regional seismicity as well as from deep drilling data (Balavadze and Shengelaya, 1961; Shengelaya, 1984). The model consisted of three main layers: sedimentary cover, the upper (granitic) crust, and the lower (basaltic) crust. The average densities of the layers inferred for seismic wave velocities and measurements were tuned to obtain a gravity model best fitting the observed regional gravity field. The depths to the Moho discontinuity are presented in Fig. 10a. This model is in a good agreement with the model of the Central European crust by Tesauro et al. (2010).

Using data from permanent and temporary broadband seismic stations and existing global seismic stations in the Anatolian plateauCaucasus-Caspian region, a 3-D velocity model was developed using joint inversion of teleseismic receiver functions and surface waves (Gök et al., 2011). The depths of major discontinuities (sediment-basement, crust-mantle, and lithosphere-asthenosphere) were inferred from the 

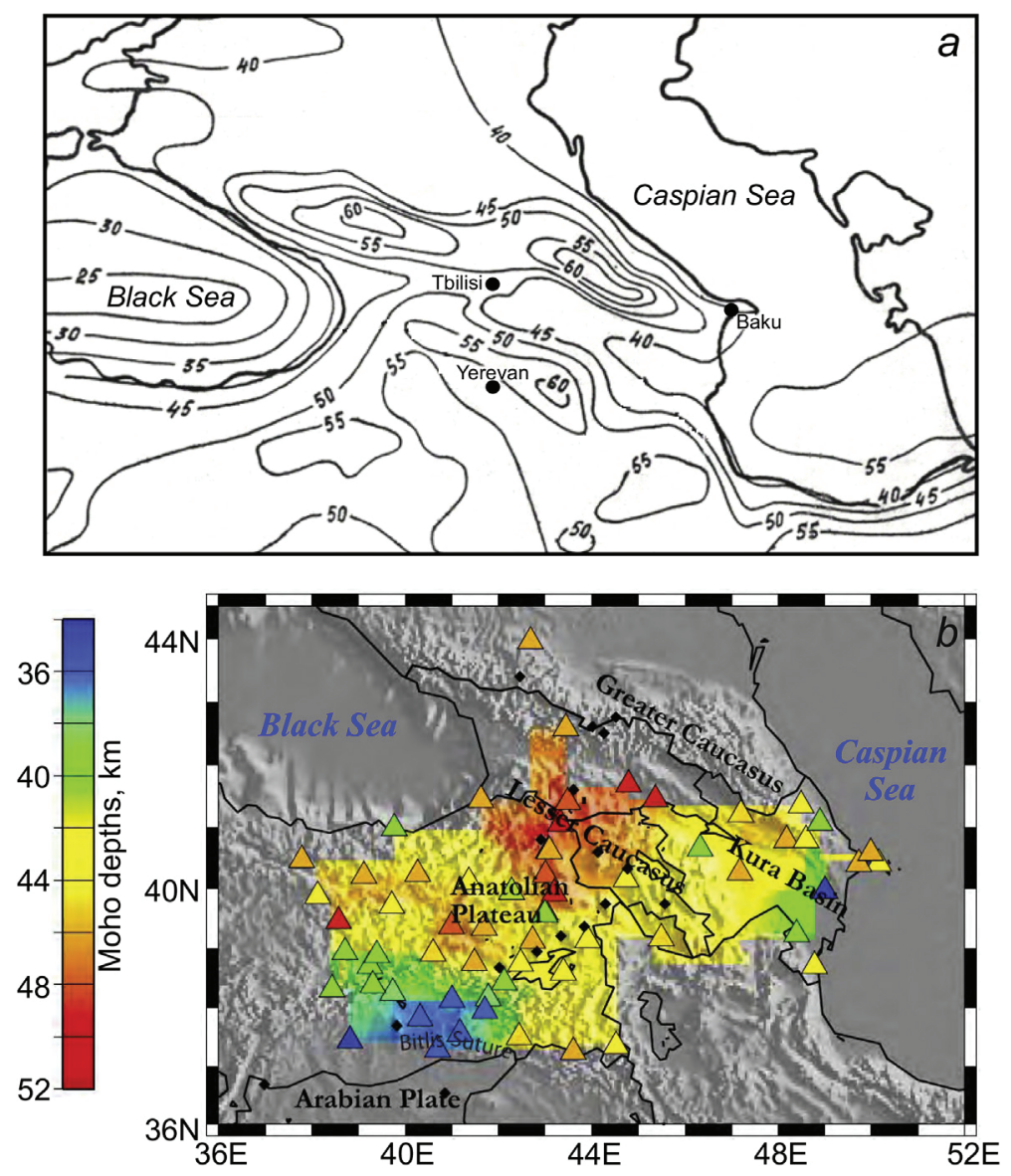

Fig. 10. Moho depths (in km) in the Black Sea - Caucasus - Caspian Sea region: (a) from Shengelaya (1984), and (b) from Gök et al. (2011).

velocity-depth profiles at the location of each station. The model showed (Fig. 10b) that under the Kura basin seismic velocities range from 2.7 to $2.9 \mathrm{~km} \mathrm{~s}^{-1}$ at the depths down to $11 \mathrm{~km}$, are about $3.8-3.9$ $\mathrm{km} \mathrm{s}^{-1}$ in the lower crust and $4.3-4.4 \mathrm{~km} \mathrm{~s}^{-1}$ in the uppermost mantle. Moho depths estimated from the shear velocity profiles were about $54 \mathrm{~km}$ at the southern edge of the Greater Caucasus, from 35 to $45 \mathrm{~km}$ in the Kura basin and at the edge of the Caspian Sea. The Moho depths obtained by Gök et al., 2011 agree with the earlier reconstructions of the Moho depths by Shengelaya (1984; Fig. 10a).

\subsection{Seismic tomography models}

Seismic tomography imaging is used to elucidate the structure of the mantle based on the measured seismic velocities or their anomalies, which can be attributed to variations in temperature, composition, and presence of melt or water (e.g., Karato, 1993, 2003; Forte et al., 1995; Griffin et al., 1998).

Several seismic tomography studies were performed in the Caucasus region and its surrounding. Al-Lazki et al. (2003) obtained tomography images of the upper mantle based on the analysis of Pn seismic velocities and showed the presence of high-velocity anomalies in the eastern Greater Caucasus. Similarly, a high-velocity body was imaged beneath the same region by waveform tomography (Maggi and Priestley, 2005). According to Al-Lazki et al. (2003), very low-velocity anomalies beneath the Lesser Caucasus and the western part of the Greater Caucasus may be related either to the presence of the partially molten and eroded mantle lid or to the absence of the mantle lid in this region with the asthenospheric material located directly beneath the crust. This interpretation challenges the earlier proposed idea of lithosphere thickening (Dewey et al., 1986) beneath the Caucasus region. If there were ever a lithospheric thickening in these regions, either delamination or convective removal of the thickened mantle lithosphere might have eliminated the thick lithosphere (Al-Lazki et al., 2003).

A teleseismic P-wave tomography image beneath the eastern end of the Lesser Caucasus close to the Kura basin show a high-velocity body down to about $200 \mathrm{~km}$, which was interpreted as a lithospheric root in the region (Zör, 2008). The same tomography study identified a negative velocity anomaly in the upper mantle beneath the central Greater Caucasus where present day high elevation is observed. According to Saintot et al. (2006), active uplift of this area since the Quaternary times might have resulted from the delamination of a lithospheric root (e.g., Ershov et al., 2003; Brunet and Cloetingh, 2003).

Koulakov et al. (2012) developed a tomography model of seismic Pand S-wave velocity anomalies for the Asian region obtained by inversion of worldwide travel time data from the catalogue of the International Seismological Centre for the period of 1964-2007. Fig. 11a presents the horizontal sections of the model at $100 \mathrm{~km}$ depth. More details of the crustal and uppermost mantle structure in the Caucasus region were revealed in the seismic model by Zabelina et al. (2016) derived based on travel times of the P- and S-waves from local earthquakes. P-wave velocity anomalies at $30 \mathrm{~km}$ depth according to this model are shown in Fig. 11b. In Fig. 11c, these models are merged in the same cross-section. Note that the regional model has limited resolution for depth layers above $50 \mathrm{~km}$, whereas the local model is resolved down to 50-70 km. In this sense, these two models are complimentary. In Fig. 11d, we present a sketch with geodynamic interpretation of the merged seismic model in the vertical section.

The velocity anomalies at $100 \mathrm{~km}$ depth in the regional model (Fig. 11a) show that the Caucasus region is squeezed between two continental plates - the Arabian plate to the south and the Eurasian plate to the north, which are displayed in the tomographic model as high-velocity bodies down to about $200-250 \mathrm{~km}$ depth. Koulakov et al. 

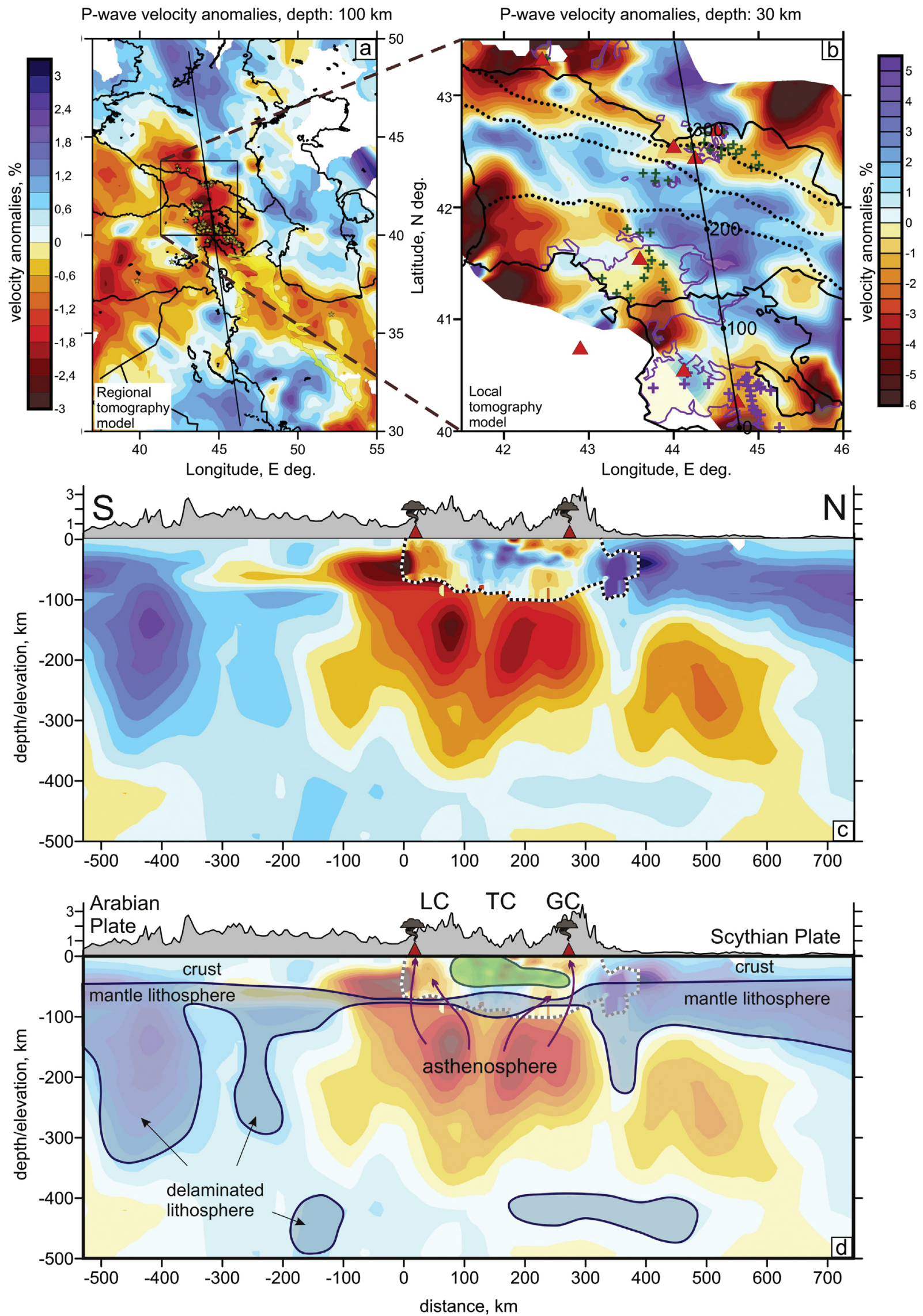

(caption on next page) 
Fig. 11. Combined results of regional and local tomography and interpretation. (a) P-wave velocity anomalies at $100 \mathrm{~km}$ depth based on the regional tomography model by Koulakov et al. (2012). Yellow polygons depict the areas of Cenozoic volcanism. Square indicates the area of the local tomography. (b) P-wave velocity anomalies at $30 \mathrm{~km}$ depth according to the local tomography model by Zabelina et al. (2016). Red triangles depict the main volcanoes; green and violet crosses indicate volcanic centres in Georgia (Tutberidze, 2011) and Armenia (Kovalenko et al., 2008), respectively. Violet contours highlight volcanic fields identified by Kovalenko et al. (2008). (c) Overlapping the local velocity model (highlighted with dotted line) over the regional model along the profile shown in (a) and (b). Red triangles indicate the locations of volcanoes in the Lesser (LC) and the Greater (GC) Caucasus. (d) Interpretation of the results of local and regional tomography. Bluish patterns highlight the parts of the mantle lithosphere; the green pattern represents the rigid block in the Transcaucasian (TC). Arrows indicate possible paths of feeding the volcanic centres.

(2012) interpreted a low-velocity anomaly beneath the Caucasus mountains as a zone where the mantle lithosphere is thin or missing. This gives low strength to the lithosphere and enables strong shortening dues to regional collisional processes. At first sight, the presence of the large low-velocity anomaly in the mantle beneath the entire Caucasus in Koulakov et al. (2012) seems to be not consistent with Zör (2008), who identified a high-velocity mantle anomaly beneath the Kura basin. This apparent difference can be explained by bias of the reference velocity values. If Koulakov et al. (2012) considered a smaller region (corresponding to the area between $-100 \mathrm{~km}$ to $350 \mathrm{~km}$ in vertical section in Fig. 11c), the average velocity would be lower, and the resulting model would appear as two low-velocity anomalies separated by the high-velocity anomaly located right below the Transcaucasian region, similarly as derived in the results by Zör (2008).

In the mantle, an alternation of seismic anomalies having the shapes of sinking drops can be seen in this tomography model between the stable continental and collision zones. Koulakov et al. (2012) proposed that the Arabian-Eurasian convergence caused crustal thickening and transformation of the lower crustal basalts into eclogites (e.g., Joyner, 1967; Ismail-Zadeh et al., 1997). When achieving a critical mass, the dense eclogitic drops triggered a detachment of the mantle lithosphere from the crust, and a movement of the asthenosphere upward toward the crust to replace the sinking pieces of the lithosphere. According to Koulakov et al. (2012), the high-velocity bodies in the tomographic model may indicate the parts of the descending mantle lithosphere, which were detached from the edges of the continental lithosphere, and the low-velocity bodies the hotter asthenosphere.

The local earthquake tomography by Zabelina et al. (2016) has revealed low-velocity anomalies in the crust beneath the Lesser and Greater Caucasus, which are separated by a prominent high-velocity anomaly beneath the Transcaucasian depression. Zabelina et al. (2016) hypothesised that this high-velocity body represents a rigid lithosphere block remaining after closing the Tethys Ocean preventing the mounting building in the large zone between the Lesser and the Greater Caucasus. In the vertical section, this block seems to underthrust northward underneath the Greater Caucasus. This rigid and resistant body might serve as a screen for mantle fluids and melts, which explains lack of volcanism in the Transcaucasian depression. The existing centres of Cenozoic volcanism in the Greater and the Lesser Caucasus seem to be associated with low-velocity anomalies in the crust that surround the high-velocity body in Transcaucasian. Although the asthenosphere beneath the Caucasus according to the regional model seems to be low-velocity, there are two zones corresponding to the Lesser and the Greater Caucasus where these anomalies are more prominent. These zones marked in Fig. 11d with red arrows possibly represent the pathways of fluids and melts causing the volcanism in the Caucasus in Cenozoic.

Based on seismic records from new permanent stations installed in the region and allowing for better seismic ray coverage, Skobeltsyn et al. (2014) imaged the uppermost mantle shear wave velocity structure of the Caucasus region using surface wave tomography. This seismic tomography model suggests a possible underthrusting of the Kura basin lithosphere beneath the Greater Caucasus, similarly, as proposed by Zabelina et al. (2016). Skobeltsyn et al. (2014) observed a high S-wave velocity anomaly beneath the eastern part of the Greater Caucasus and the Kura basin from subcrustal depths down to $250 \mathrm{~km}$, which is consistent with the body-wave teleseismic tomography results by Zör (2008). This structure does not contradict to the results by Koulakov et al. (2012), in which the local increase of velocity within the large low-velocity anomaly corresponds to the high-velocity anomaly in Skobeltsyn et al. (2014). The high S-wave velocity body appears to be slightly smeared to the east at depths up to $75 \mathrm{~km}$ creating an elongated positive velocity anomaly below Absheron-Balhan Sill, where the south Caspian block is believed to subduct northward beneath the lithosphere of the middle Caspian Basin (e.g., Jackson et al., 2002).

The acceleration in uplift during the early Pliocene in the central and eastern Greater Caucasus was considered to be caused by lateral translation of the compressive stress field produced by the converging Arabian Plate (e.g., Philip et al., 1989; Allen et al., 2003; Saintot et al., 2006). An alternative explanation of the post-Miocene rapid exhumation of the Greater Caucasus involves the onset of a flat subduction of the back-arc basin, which existed between the Eurasia and the Pontide arcs (Avdeev and Niemi, 2011), and this would imply that the modern Kura basin's evolution is associated with a small-scale subduction occurring along the eastern margin of the Greater Caucasus (Skobeltsyn et al., 2014). The existence of several subduction zones within the shortening continental zones is considered by Doglioni et al. (2007) as a clue to unravel the structure and kinematics of this type of orogens. They propose that the NE-directed continental subduction has the slab hinge converging relative to the upper plate, generating a double verging orogen (see also Forte et al., 2014).

\section{Dynamics of the lithosphere and earthquakes}

Tectonic loading of lithospheric blocks leads to deformation, progressive strain accumulation, and the intermittent earthquake release. Seismic and geodetic studies in the Caucasus reveal the strong strain partitioning with distinct patterns of regional deformation, strain and stress fields. The reason for these differences resides in the inherited lithospheric structure resulting from the collage of successive terrain with different properties, and hence a block model may be appropriate to describe the structure of the lithosphere in the region (e.g., Aktug et al., 2013; Karakhanyan et al., 2013). Geological, paleomagnetic, palinspatic, and paleobiogeographic data provide evidence that these terranes, before being accreted together into a single complex of foldand-thrust belts, underwent long-term and substantial horizontal displacements within the now-vanished oceanic area of the Tethys. The boundary zones between these terrains represent belts of intense tectonic, volcanic, and seismic activities (e.g., Adamia et al., 2017). The main part of active faults represents the boundaries of the main tectonic units of the region and hosts the foci of strong earthquakes (Adamia et al., 2008, 2011; Varazanashvili et al., 2011).

A morphostructural zoning helps to identify the hierarchical block structure of the Caucasus and earthquake-prone areas in the region (e.g., Gvishiani et al., 1988; Gorshkov et al., 1991, 2003; Novikova and Gorshkov, 2018). On the basis of the joint analysis of the geomorphologic, geological, fault and satellite data, the morphostructural zoning delineates three classes of structures: the blocks of various hierarchical levels, the active zones (lineaments) bordering these blocks, and the intersections of the lineaments (nodes). Using the morphostructural zoning, Soloviev and Gorshkov (2017) developed a hierarchical 

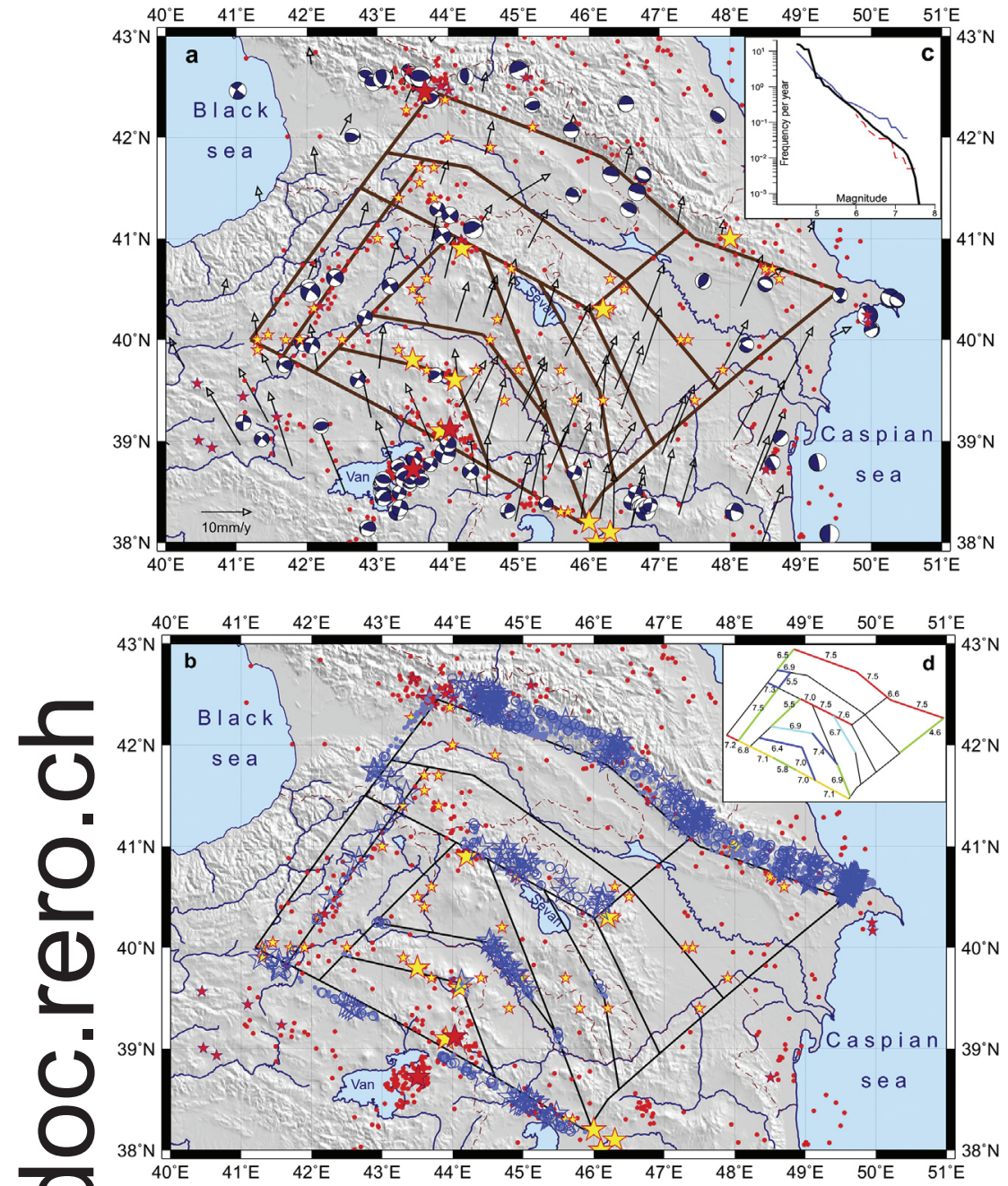

Fig. 12. A model of block-and-fault dynamics in the Caucasus region. (a) Map of the Caucasus region with earthquakes presenting the block model (brown lines). The block structure is delineated on the basis of the block structure model by Karakhanyan et al. (2013), the geomorphological model by Soloviev and Gorshkov (2017), the active fault structure and the spatial distribution of earthquakes (Trifonov et al., 1994; Avagyan et al., 2010), and geodetic data (e.g., Reilinger et al., 2006; Djamour et al., 2011; Karakhanyan et al., 2013; Kadirov et al., 2015). Instrumentally recorded earthquakes are marked by red dots (magnitude M4.5+), by small red stars (M6+), and big red starts (M7+) (ANSS catalogue for the period of 1974-2017). Historical strong earthquakes as well as instrumentally recorded seismicity for the period from 1000 to 1973 are marked by small yellow starts (M6+) and big yellow starts (M7+) (Ulomov and Medvedeva, 2014). Black arrows: GPS velocities (Vernant and Chery, 2006; Djamour et al., 2011; Karakhanyan et al., 2013). Black-white balls are the earthquakes mechanisms obtained from the Global Centroid-Moment-Tensor solution (https://www.globalcmt.org/). (b) Distribution of synthetic seismicity (with earthquake magnitudes greater than 6) imposed on the map of observed seismicity: blue stars mark earthquakes of magnitude M7 +, blue circles M6.5 + events, and light blue dots M6 + events. (c) Insert: Frequency-magnitude relationship for earthquakes in the Caucasus region. The blue curve represents the data from the ANSS earthquake catalogue; the red curve represents the data from Ulomov and Medvedeva (2014) since 1800, $\mathrm{M} \geq 6.0$; and the black curve corresponds to the synthetic events. (d) Insert: Focal mechanisms of synthetic earthquakes on the faults (indicated by fault segment's colours) and the maximum magnitude of synthetic earthquakes on each fault segment (marked by the number at the segments). Types of faulting: normal (blue), normal - strike-slip (light blue), strike-slip (green), reverse - strike-slip (yellow), and reverse (red). Modified after Vorobieva et al. (2019). network of lineaments for the Caucasus correlating with the major active faults mapped in the region (Fig. 5; Trifonov et al., 1994; Karakhanyan et al., 2004). Employing pattern recognition algorithms and machine learning techniques, areas potentially prone to earthquakes with magnitude M5 + (Gvishiani et al., 1988; Gorshkov et al., 1991) and earthquakes with M6 + (Soloviev et al., 2013) were recognized in the region. Soloviev et al. (2016) argued that the lithospheric magnetic anomalies help in recognizing the areas prone to the strong earthquakes.

As recorded earthquake catalogues cover normally a time interval of about a century, which is significantly shorter than the duration of tectonic processes responsible for the seismic activity, numerical simulations generate long catalogues of synthetic seismicity and help to study the patterns of earthquake occurrence unidentifiable in existing catalogues. A block-and-fault dynamics (BAFD) model simulates earthquakes due to dynamics of lithospheric blocks and allows for studying the influence of fault network properties and regional movements on seismic patterns (e.g., Soloviev and Ismail-Zadeh, 2003; Ismail-Zadeh et al., 2007, 2018; Vorobieva et al., 2014, 2017). The BAFD model was applied to study the dynamics of the crustal blocks and seismicity in the Caucasus (Soloviev and Gorshkov, 2017; IsmailZadeh et al., 2018; Vorobieva et al., 2019).

Fig. 12 shows the spatial distribution of the epicentres of the observed (a) and synthetic earthquakes with magnitude $M \geq 6$ (b). The model confirms that the modern crustal dynamics and seismicity pattern in the Caucasus are determined by the N-NE-ward motion of the Arabian plate relative to Eurasia. The BAFD catalogue covers synthetic seismic events for 10,000 years, which is by about two orders of magnitude larger than the existing earthquake catalogues. Synthetic strong earthquakes mimic the regional seismicity; the slope of the frequency-magnitude plot for synthetic events (Fig. 12c) shows a good agreement with that for observed regional seismicity in the magnitude range from 5 to 7.5 . The focal mechanisms of synthetic seismicity confirm the regional stress state pattern (Fig. 12d). The strongest modeled thrust-fault events $(M 7+)$ are associated with the southern foot of the Greater Caucasus mountains and the northern Lesser Caucasus, where strong earthquakes were observed and instrumentally recorded since the 1902 Shamakha earthquake. Vorobieva et al. (2019) showed that the average recurrence time intervals of strong synthetic events are in a good agreement with those derived from observations. Also, their model predicts strong seismic events to occur along the Nakhchivan fault. Although no strong earthquakes were observed at the fault so far, seismic hazard associated with the fault should not be neglected. If M7 + earthquake happens on the fault, it may generate serious damage in Yerevan (Armenia) and Nakhchivan (Azerbaijan).

\section{Seismic hazard and risk}

The community of seismologists and earthquake engineers considers a seismic hazard in terms of engineering parameters of strong ground motion, namely, peak ground acceleration/velocity or seismic intensity. However, seismic hazard assessment (SHA) should be considered in more holistic way integrating seismological, geomorphological, geological, near-surface, and tectonic investigations (e.g., Ismail-Zadeh, 2014, 2018). Seismic hazard assessments were performed for the Caucasus region in the framework of several national and international 
projects (e.g., GSHAP, EMME). The Global Seismic Hazard Assessment Program (GSHAP) conducted in 1990's established a common framework to evaluate the seismic hazard over large geographical regions. One of its main regional products was seismic hazard assessment map for the Caucasus test area (Balassanian et al., 1999). Several methods for seismic hazard assessments were used during the GSHAP performance to analyse seismic hazard in the region: deterministic, probabilistic and their combinations. We refer to Balassanian et al. (1999) for description of the seismic hazard methods, analysis and the results of the hazard assessment for the Caucasus.

The EMME (Earthquake Model of Middle East) project aimed to evaluate the seismic hazard and the associated risks in the Middle East and the Caucasus (Erdik et al., 2012). The earthquake (area and fault) source model for the EMME region comprised of seismogenic sources defined by geological evidences, active tectonics, and seismicity patterns is presented by Danciu et al. (2018a). A ground motion logic tree, built to account for the epistemic uncertainties of the ground motion, was derived for each tectonic region, including the Caucasus (Danciu et al., 2018b). A probabilistic framework was implemented for assessing the seismic hazard of the EMME region. The OpenQuake probabilistic seismic hazard assessment (PSHA) tool was used for hazard calculation in the EMME region (Pagani et al., 2014). The tool allows for computing possible ground motions with a given probability of being exceeded at every location in the EMME region within 50 years and for all relevant intensity measure types, e.g., peak ground acceleration (PGA) and response spectral acceleration (Şeşetyan et al., 2018). Fig. 13a presents the seismic hazard map for the Caucasus region showing mean PGAs, which may be exceeded with probability 0.1 in 50 years. A comparison of this hazard map with the GSHAP map
(Giardini, 1999) for the same region reveals an increased level of detailing in the seismic hazard distribution due to the incorporation of a fault source model (Şeşetyan et al., 2018). A closer look to the hazard results for capital cities of Azerbaijan (Baku), Armenia (Yerevan), and Georgia (Tbilisi) shows that mean PGA is $0.247 \mathrm{~g}$ for Baku (Fig. 13b), $0.279 \mathrm{~g}$ for Tbilisi (Fig. 13c), and $0.285 \mathrm{~g}$ for Yerevan (Fig. 13d).

Comprehensive seismic hazard assessment can be significantly enhanced by using geodetic measurement of strain rates. The rate of strain release by earthquakes is linked to the effective rate of tectonic deformation due to steady-state tectonic loading (Main, 1996). Measurements of crustal deformation can be translated in estimates of the average frequency and magnitude of the largest events (Kagan, 2002). Kadyrov et al. (2012) estimated the strain rates in the central and eastern Caucasus from geodetic observations and showed that the epicentres of earthquakes of $\mathrm{M} \geq 5$ are mainly confined to the gradient zone of deformations.

Earthquakes in the Caucasus region caused several disasters in the 20th century including the 1902 Shamakha earthquake, the 1988 Spitak earthquake, and the 1991 Racha earthquake. Not every strong earthquake results in a disaster, but that which interacts with high vulnerability of building constructions and of population concerned. To understand risks associated with earthquakes, a co-designed and coproductive work of many stakeholders involved in risk reduction should be conducted and results of the work should be linked to policymakers (Cutter et al., 2015; Ismail-Zadeh et al., 2017; Ismail-Zadeh, 2018). An assessment of economic risk in the Transcaucasian states has shown that earthquakes are the dominant disaster risk; namely, earthquakes represent the dominant risk in Armenia followed by droughts and floods; droughts, floods and earthquakes are significant risks in
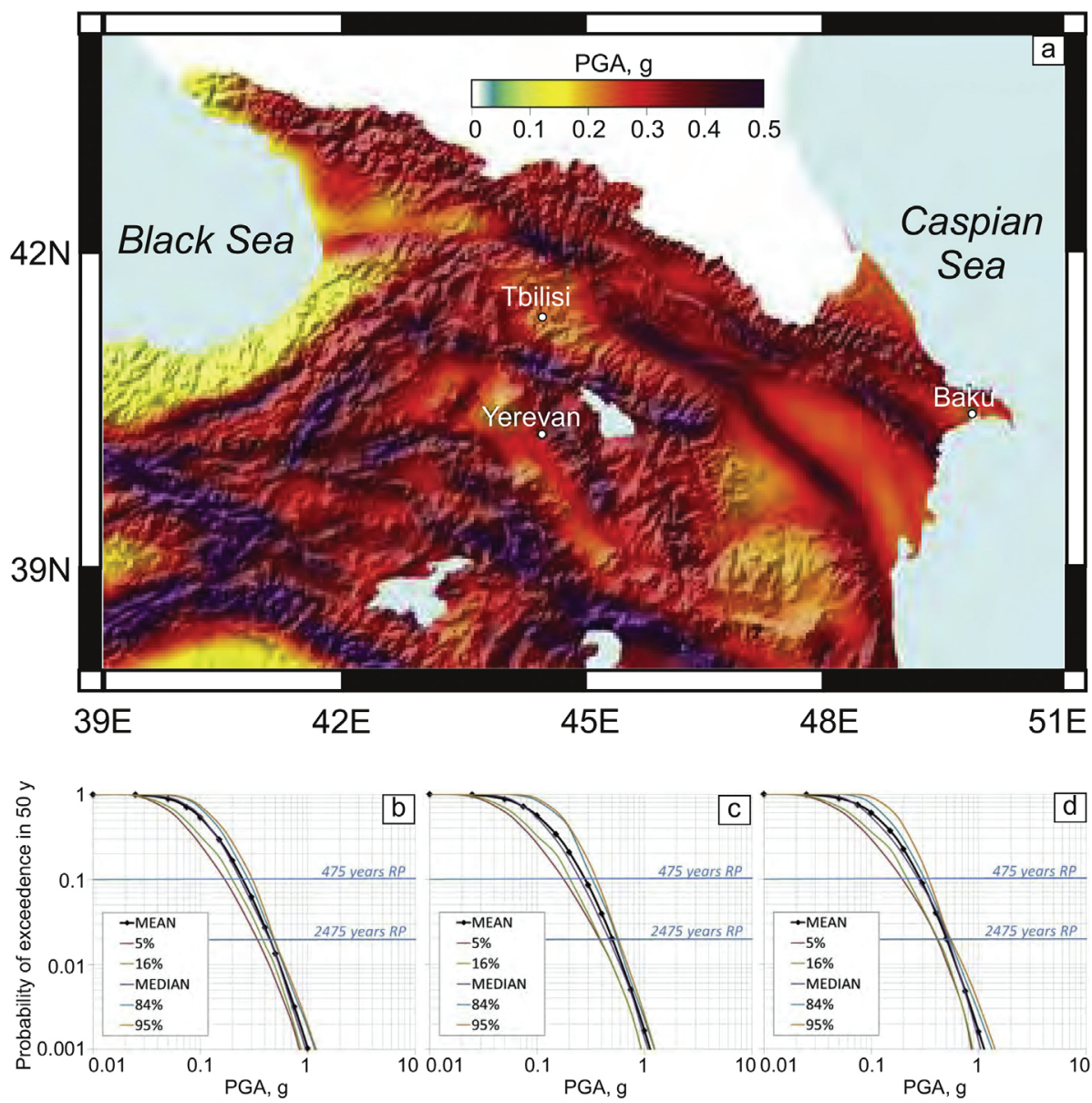

Fig. 13. (a) Probabilistic seismic hazard map showing the mean peak ground acceleration (PGA) distribution with probability 0.1 of exceedance in 50 years (475 years return period) for a hard rock. The mean and quantile hazard curves for Baku (b), Tbilisi (c), and Yerevan (d). Data from Şeşetyan et al. (2018). 
Azerbaijan, and landslides and earthquakes are significant risks in Georgia (CAC DRMI, 2009).

Several studies were performed to analyse seismic risk in the Caucasus region (e.g., Babayev et al., 2010; Varazanashvili et al., 2012; Tsereteli et al., 2012, 2014). A rapid growth of population, intensive civil and industrial building, land and water instabilities, and the lack of public awareness regarding seismic hazard contribute to the increase of vulnerability to earthquakes. Babayev et al. (2010) assessed an earthquake risk in Baku determined as a convolution of seismic hazard, vulnerability (due to building construction fragility, population features, the gross domestic product per capita, and landslide's occurrence), and exposure of infrastructure and critical facilities. The earthquake risk assessment provided useful information to identify the factors influencing the risk. A deterministic seismic hazard for Baku was initially analysed for several earthquake scenarios. The seismic hazard models by Babayev et al. (2010) demonstrated the level of ground shaking in the city: PGA high values are predicted in the southern coastal and north-eastern parts of the city and in some parts of the downtown. It was shown that the quality of buildings and the probability of their damage, the distribution of urban population, exposure, and the pattern of peak ground acceleration contribute to the seismic risk. Meanwhile the physical vulnerability factors play a prominent role for all earthquake scenarios. Varazanashvili et al. (2012) evaluated vulnerability and economic losses due to natural (including seismic) hazards in Georgia using the gross domestic product per unit area (applied to population) as the indicator for elements at risk exposed. The correlation between estimated economic losses, physical exposure and seismic hazards was analysed. Based on the PSHA map, Tsereteli et al. (2014) assessed the earthquake risk and predicted damage and casualty for a given probability of earthquake recurrence.

\section{Conclusions and outlook}

The Caucasus region represents the northernmost edge of the ongoing collision of the AR-EU plates. The tectonic development of the Caucasus region in the Mesozoic-Cenozoic times was complex as well as the underlying dynamics controlling its development. The collision is responsible for the topographic uplift / inversion and for the formation of the fold-and-thrust belts of the Greater and Lesser Caucasus. Tectonic deformations in the region are influenced by the wedge-shaped rigid Arabian block indenting into the relatively mobile region and producing near N-S compressional stress and seismicity in the Caucasus.

In this section, we look at the gaps in the current geological and geophysical knowledge of the Caucasus region and consider still unresolved problems, particularly emphasizing which datasets should be developed and which kind of studies should be conducted in the region to address the problems. Several geological and geodynamic points should still be clarified: (i) What is the origin of the lithosphere (oceanic versus thin continental) beneath the Caucasus? Which type of geodynamic processes has been influencing the tectonic evolution of the region: oceanic slab subduction, roll-back and detachment or continental lithosphere delamination? (ii) What is the age of the ongoing continental collision? How precise is our knowledge on the temporal and spatial features of shortening and exhumation? What is the role of Daralagöz and related obduction in the framework of different regional paleoreconstructions? Does the proposed Borjomi-Kazbegi fault exist? (iii) What should be done to improve the quality of seismic, gravity, and thermal models of the Caucasus region? How to develop reliable seismic hazards and risks models in the region?

\subsection{Comprehensive regional datasets}

A fundamental problem in studying seismicity within the Caucasus is the lack of a comprehensive earthquake catalogue for the entire region, which should cover the countries of Armenia, Azerbaijan, Georgia, north-western Iran, the southern part of Russia, and eastern
Turkey. Each country mentioned maintain independently seismic networks and databases. However, the local data are not always publicly available and will require extensive effort to compile considering political relations in the region. Meanwhile, some efforts have been made to compile the databases. For example, Mumladze et al. (2015) developed a composed catalogue of regional earthquake hypocentre locations combining records from several sources for the period of 1961 to 2013. A comprehenvise dataset on regional seismicity, refined from errors and event duplications and composing of well-defined earthquake hypocentres, magnitudes, and fault plane solutions, together with local and regional seismic tomography studies can help in understanding the crustal and uppermost mantle structure beneath the Caucasus.

New satellite-based gravity models should be developed for the region to interpret the deeper part of the mountain range and lithosphere structure. The existing national gravity surveys in the Caucasus region (complimentary to the Soviet Union's survey) are to a large extent incomplete and not uniform. This makes almost impossible to develop a consistent gravity map for the entire region. New satellite data (CHAMP, GRACE and especially GOCE) provide a basis for development of a homogeneous model. Particularly, the global EIGEN-6c4 model (Förste et al., 2014) is based on a combination of the satellite and terrestrial data and allows for a spatial resolution of about $5^{\prime} \times 5^{\prime}$ of the gravity disturbances. This dataset can be supported with detailed seismic studies (e.g., using teleseismic tomography and receiver function investigations) with the increased numbers of seismological stations. New data could provide details of the regional crustal (e.g., the Moho structure beneath the Caucasus) and lithosphere structure.

A permanent geodetic monitoring in the region is required to analyse local deformations, to contribute to the understanding of the Caucasus tectonics, and to further improve seismic hazards assessments contributing to disaster risk reduction. Particularly, such geodetic monitoring could contribute to the ongoing debates on existence of Transcaucasian faults (across the EW-oriented faults; see Fig. 5). For example, a postulated left-lateral Borjomi-Kazbegi fault proposed by Philip et al. (1989) was considered as the western boundary of the actively indenting wedge. However, some geomorphological and geological studies showed no displacement of the Early and Middle Eocene sediments in the Borjomi area (O'Connor et al., 2006). Meanwhile, recent geodetic studies in the region (e.g., Reilinger et al., 2006; Kadirov et al., 2015) may be interpreted as an evidence for the existence of a Transcaucasian fault zone but different from the BKF location proposed earlier (Chelidze, 2018).

\subsection{Regional models of geodynamic and tectonic evolution}

The origin of deep earthquakes in the eastern Greater Caucasus - the adjacent Caspian Sea region is still debated. The lower crustal and subcrustal seismicity beneath the northern foothills of the eastern Greater Caucasus, the Absheron peninsula, and the Middle Caspian Sea as well as subsidence modelling in the South Caspian Sea indicate that the oceanic crust of the South Caspian Sea began subducting beneath the southern margin of the Middle Caspian Sea to the east in the PlioceneQuarternary (e.g., Neprochonov et al., 1970; Mangino and Priestly, 1998; Allen et al., 2002; Brunet et al., 2003). Mumladze et al. (2015) observe a gap in intermediate-depth seismicity $(45-75 \mathrm{~km}$ ) at the western end of the subducted slab beneath the central Greater Caucasus, which was interpreted as an eastward-propagating tear. This tear coincides with a region of minimum horizontal convergence rates between the Lesser and the Greater Caucasus, as expected in a region of active slab breakoff. According to Mumladze et al. (2015) active subduction beneath the eastern Greater Caucasus presents a significant seismic hazard and may explain historical records of magnitude 8 earthquakes in the region.

The subduction scenarios are also debatable. Modelling of the density structure of the lithosphere in the Caucasus and the surrounding 
areas suggests that the Scythian plate partially underthrusts the western Greater Caucasus. Considering the lack of surface geology evidence of this process, Kaban et al. (2018) hypothesized that the undertrust could be the initial stage of the subduction polarity reversal after the break off of the plate formerly subducted northward. Thermal models of the Caucasian lithosphere based on seismic and borehole temperatures can assist in elucidating the crustal and uppermost mantle structure.

Meanwhile, available geological data demonstrate that the Greater Caucasus Basin developed on a strongly (hyper-) stretched continental crust, but no oceanic floor was created. A lack of geologic signatures of subduction, including the apparent absence of an ophiolitic suture, a volcanic arc, an accretionary complex, or exposures of blueschist or high-grade metamorphic rocks is also cited as evidence against subduction being active during formation of the Greater Caucasus (e.g., Mosar et al., 2010). The recent volcanoes are located westward, in the central part of the range from Kazbegi till Elbrus. Lithospheric folding due to indentation of the Africa-Arabian and Indian plates could also explain the existence of sub-crustal earthquakes in the easternmost Caucasus - Caspian Sea region (Luth et al., 2010; Cloetingh and Burov, 2011; Smit et al., 2013).

The controversy related to the interpretations of the observed subcrustal seismicity in the Greater Caucasus region is similar to that associated with the intermediate-depth seismicity in the Vrancea region of the southeastern Carpathians. Although several seismic tomography studies imaged a high-velocity anomaly body in the uppermost mantle, and the sub-crustal earthquakes are likely to occur as a response to tectonic stresses induced by the body, so far there is no consensus about the origin of the body - whether it is a piece of the relic continental lithosphere or a relic oceanic slab - and hence about the type of geodynamic processes taking place in the region - descending oceanic slab, slab detachment or delamination of the continental lithosphere (for a review of geodynamics and seismicity in Vrancea, see Ismail-Zadeh et al., 2012). Thus, to understand the origin of sub-crustal earthquakes in the easternmost Caucasus - Caspian Sea region, further in-depth geophysical, seismological and geological studies are required.

GPS velocities show active deformation occurring in the South Caucasus with a strong velocity gradient along the line dividing eastern and western parts of the Caucasus (Fig. 9 a, b). The western Caucasus, containing the highest peaks in the range and significant exposures of Paleozoic metamorphic and igneous rocks, is shortening at about $2 \mathrm{~mm}$ $\mathrm{y}^{-1}$, and has low rates of seismicity. Meanwhile the eastern part of the Caucasus, which is lower in elevations and still comprised of Mesozoic sedimentary strata, is shortening at rates up to $14 \mathrm{~mm} \mathrm{y}^{-1}$, and it is quite active seismically (Kadirov et al., 2015). Fault patterns, GPS motions, seismicity, and density structure (Mosar et al., 2010; Mumladze et al., 2015; Kadirov et al., 2015; Kaban et al., 2018) indicate that the eastern and western parts of the Greater Caucasus have distinct geodynamic settings. Additional geodetic investigations together with low-temperature thermochronology (to constrain the time-temperature history of rocks and to provide constraints on tectonic history of the region) may elucidate the difference between long-term tectonic strain and present strain rate, and the duration of the geodynamic difference between the two parts of the Caucasus.

\subsection{Seismicity and earthquake hazards}

Given the increase in the population and the extensive infrastructural development in the Caucasus region, and the likelihood of gaining new insights from additional geodetic observations and a complex fault structure, it is essential that further studies be focused on the possibility and effects of damaging earthquakes. Densifying GPS coverage in the western and eastern Caucasus with its extension into the Caspian Sea and combining them with (paleo-) seismological studies and historic earthquake records will provide the constraints needed to clarify better earthquake hazards in the region.

Whereas tectonic stress orientations in the Caucasus region are rather well documented, stress magnitudes are unknown. Meanwhile, from the simultaneous occurrence of strike slip and thrust faulting events one might speculate that the minimum horizontal stress and the vertical stress are of the same order of magnitude. To determine the minimum horizontal stresses stress analysis should be undertaken in drilled boreholes in the area of the simultaneous occurrence of different faulting-mechanism events.

Our present knowledge about seismicity in the Caucasus is based on observed (recorded) data and available historical data obtained mostly from archaeological studies, written stories about intensities of large earthquakes and some other sources. The information about large events in the Caucasus in the geological past is incomplete. Modelling of seismic events using earthquake simulators can overcome the difficulties in SHA by combination of observations, historic data and modelled results (e.g., Sokolov and Ismail-Zadeh, 2015, 2016; Console et al., 2017). Particularly, Sokolov and Ismail-Zadeh (2015) developed a new approach to a Monte-Carlo probabilistic SHA combining the observed regional seismicity with large magnitude synthetic events obtained by earthquake simulations. This approach was employed for seismic hazards analysis in the Tibet-Himalayan region, and showed an advantage compared to the standard probabilistic SHA (e.g., Giardini, 1999). Application of the approach to the Caucasus region may contribute to enhanced assessment of seismic hazard.

Monitoring of seismicity and strain in the Caucasus in combination with geological and geophysical studies and earthquake simulation and hazard modelling can assist in recognition of future earthquake sources. All these scientific studies and new knowledge will lead to better understanding of the evolution of the Caucasus, the present tectonics and seismicity in the region, and finally will assist in reliable assessment of seismic hazards and mitigation of seismic risk in the region.

Declaration of Competing Interest.

None.

\section{Author contributions}

AIZ proposed conducting a survey in geodynamics, seismicity and seismic hazard in the Caucasus region, gathered a team of authors to write the paper, collected research material from the co-authors, contributed scientifically to sects. 1, 3-9, and drafter the paper. AC, AG, SA, SC, TK, TM, and JM contributed to sect. 2; JKe and TC to sect. 3; BM, FS, and NS to sect. 4; FK and MK to sects. 5; FK, MF, and RS to sect. 6; AG, IK, JKa, TC ad TI to sect. 7; and AS, BM, and FS to sect. 8. All authors contributed to discussion of the paper and to sect. 10 .

\section{Acknowledgments}

The authors are grateful to Carlo Doglioni (editor) and three anonymous reviewers for their constructive comments. Special thanks go to William Cavazza for his thorough review of the initial manuscript and insightful suggestions for revision, which significantly improved the manuscript. This research was supported by the German Science Foundation (DFG IS-203/4-1), the German Federal Ministry of Education and Research (BMBF FKZ 03G0882A), Shota Rustaveli National Science Foundation of Georgia (SRNSF 217942), and the Russian Science Foundation (19-17-00027).

\section{References}

Adamia, Sh., 1975. Plate tectonics and evolution of the Alpine system: Discussion. Geol. Soc. Am. Bull. 86, 719-720.

Adamia, Sh., Lordkipanidze, M., Zakariadze, G., 1977. Evolution of an active continental margin as exemplified by the Alpine history of the Caucasus. Tectonophysics 40, 183-199.

Adamia, Sh., Chkhotua, T., Kekelia, M., Lordкipanidze, M., Shavishvili, I, Zakariadze, G., 1981. Tectonics of the Caucasus and adjoining regions: implications for the evolution of the Tethys ocean. J. Struct. Geol. 3 (4), 437-447.

Adamia, Sh., Gugunishvili, G., Kuparadze, D., Lordkipanidze, M., Khutsishvili, O., 1989. Pre-Upper Jurassic serpentinite mélange in Southern Georgia (Sadakhlo). Bulletin of 
the Academy of Sciences of the Georgian SSR 134 (2), 357-360.

Adamia, Sh., Lordkipanidze, M., Beridze, M., Kotetishvili, E., Kutelia, Z., 1990. Evolution of the Northern Margin of Tethys: The results of IGCP project 198. V. III. Memoires de la Societe Geologique de France, Paris, Vouvelle Serie \#154(III), Occasional Publications ESRI, New Series \#5.Evolution of the Northern Margin of Tethys: The results of IGCP project 198. V. III. Memoires de la Societe Geologique de France, Paris, Vouvelle Serie \#154(III), Occasional Publications ESRI, New Series \#5.

Adamia, Sh., Mumladze, T., Sadradze, N., Tsereteli, E., Tsereteli, N., Varazanashvili, O., 2008. Late Cenozoic tectonics and geodynamics of Georgia (SW Caucasus). Georgian Int. J. Sci. Technol. 1 (1), 77-107.

Adamia, Sh., Alania, V., Chabukiani, A., Chichua, G., Enukidze, O., Sadradze, N., 2010a. Evolution of the Late Cenozoic basins of Georgia (SW Caucasus): a review. In: Sosson, M., Kaymakci, N., Stephenson, R.A., Bergerat, F., Starostenko, V. (Eds.), Sedimentary Basin Tectonics from the Black Sea and Caucasus to the Arabian Platform, pp. 239-259 Geological Society, London, Spec. Publ.

Adamia, Sh., Chabukiani, A., Chkhotua, T., Sadradze, N., Zakaraia, D., Zakariadze, G., compilers, 2010b. Geological Map of the Caucasus: Tbilisi, Georgia, M. Nodia Institute of Geophysics, I. Javakhishvili Tbilisi State University, scale 1:1,000,000.

Adamia, Sh., Zakariadze, G., Chkhotua, T., Sadradze, N., Tsereteli, N., Chabukiani, A., Gventsadze, A., 2011. Geology of the Caucasus: a review. Turk. J. Earth Sci. 20 (5), 611-628.

Adamia, Sh., Chabukiani, A., Chkhotua, T., Enukidze, O., Sadradze, N., Zakariadze, G., 2017a. Tethyan evolution and continental collision in Georgia. In: Sorkhabi, R. (Ed.), Tectonic Evolution, Collision, and Seismicity of Southwest Asia: In Honor of Manuel Berberian's Forty-Five Years of Research Contributions. Geol. Soc. Amer. Spec. Papers 525. pp. 501-535.

Adamia, Sh., Alania, V., Tsereteli, N., Varazanashvili, O., Sadradze, N., Lursmanashvili, N., Gventsadze, A., 2017b. Postcollisional tectonics and seismicity of Georgia. In: Sorkhabi, R. (Ed.), Tectonic Evolution, Collision, and Seismicity of Southwest Asia: In Honor of Manuel Berberian's Forty-Five Years of Research Contributions. Geol. Soc. Amer. Spec. Papers 525. pp. 535-573.

Adamia, Sh., Chkhotua, T., Gavtadze, T., Lebanidze, Z., Lursmanashvili, N., Sadradze, N., Zakaraia, D., Zakariadze, G., 2017c. Tectonic setting of Georgia-eastern Black Sea: a review. In: Sosson, M., Stephenson, R., Adamia, S. (Eds.), Tectonic Evolution of the Eastern Black Sea and Caucasus, Geol. Soc. Spec. Publ. 428. Geological Society, London, pp. 11-41.

Agamirzoyev, R.A., 1987. Seismotectonic of Azerbaijanian Part of Greater Caucasus. Baku, Elm (in Russian).

Agard, P., Omrani, J., Jolivet, L., Mouthereau, F., 2005. Convergence history across Zagros (Iran): constraints from collisional and earlier deformation. Int. J. Earth Sci. 94, 401-419.

Ahadov, B., Jin, S., 2017. Present-day kinematics in the Eastern Mediterranean and Caucasus form dense GPS observations. Phys. Earth Planet. Inter. 268, 54-64.

Ahadov, B., Jin, S., 2019. Effect of Coulomb stress change on $M_{W}>6$ earthquakes in the Caucasus region. Phys. Earth Planet. Inter. 297, 106326.

Ahmedbeyli, F.S., Gasanov, A.G., Kuliyev, F.T., Panahi, B.M., 1991. The new schemes of the areas of strongest earthquake sources occurrence and seismic zoning of Azerbaijan territory. In: Shikhalibeyli, A.Sh. (Ed.), The Catalogue of Seismic Prognostic Observations in Azerbaijan in 1987. Elm, Baku, pp. 62-65 (in Russian).

Aktuğ, B., Meherremov, E., Kurt, M., Özdemir, S., Esedov, N., Lenk, O., 2013. GPS constraints on the deformation of Azerbaijan and surrounding regions. J. Geodyn. 67, $40-45$

Alania, V.M., Chabukiani, A.O., Chagelishvili, R.L., Enukidze, O.V., Gogrichiani, K.O., Razmadze, A.N., Tsereteli, N.S., 2017. Growth structures, piggy-back basins and growth strata of the Georgian part of the Kura foreland fold-thrust belt: implications for Late Alpine kinematic evolution. Geol. Soc. Lond. Spec. Publ. 428, 171-185.

Alavi, M., 1994. Tectonics of the Zagros orogenic belt of Iran: new data and interpretations. Tectonophysics 229, 211-238.

Albino, I., Cavazza, W., Zattin, M., Okay, A., Adamia, Sh., Sadradze, N., 2014. Far-field tectonic effects of the Arabia-Eurasia collision and the inception of the North Anatolian fault system. Geol. Mag. 151 (2), 372-379.

Alexidze, M., Gugunava, G., Kiria, D., Chelidze, T., 1993. A three-dimensional stationary model of the thermal and thermoelastic fields of the Caucasus. Tectonophysics 227 , 191-203 and Erratum, 1995. Tectonophysics 243, 297-298.

Aliyev, A., Guliyev, I.S., Belov, I.S., 2002. Catalogue of Recorded Eruptions of Mud Volcanoes of Azerbaijan. Nafta Press, Baku.

Al-Lazki, A., Seber, D., Sandvol, E., Türkelli, N., Mohamad, R., Barazangi, M., 2003. Tomographic Pn velocity and anisotropy structure beneath the Anatolian plateau (eastern Turkey) and the surrounding regions. Geophys. Res. Lett. 30 (24), 8043. https://doi.org/10.1029/2003GL017391.

Allen, M.B., Armstrong, H.A., 2008. Arabia-Eurasia collision and the forcing of midCenozoic global cooling. Palaeogeogr. Palaeoclimatol. Palaeoecol. 265, 52-58.

Allen, M.B., Jones, S., Ismail-Zadeh, A., Simmons, M., Anderson, L., 2002. Onset of subduction as the cause of rapid Pliocene-Quaternary subsidence in the South Caspian basin. Geology 30, 775-778.

Allen, M., Vincent, S., Alsoop, G., Ismail-Zadeh, A., Flacker, R., 2003. Late Cenozoic deformation in the south Caspian region: Effects of a rigid basement block within a collision zone. Tectonophysics 366, 223-239.

Allen, M., Jackson, J., Walker, R., 2004. Late Cenozoic reorganization of the ArabiaEurasia collision and the comparison of short-term and long-term deformation rates. Tectonics 23, TC2008. https://doi.org/10.1029/2003TC001530.

Ambraseys, N.N., Jackson, J.A., 1998. Faulting associated with historical and recent earthquakes in the Eastern Mediterranean region. Geophys. J. Int. 133, 390-406.

Artemieva, I.M., Shulgin, A., 2019. Geodynamics of Anatolia: lithosphere thermal structure and thickness. Tectonics 38. https://doi.org/10.1029/2019TC005594.

Avagyan, A., Sosson, M., Philip, H., Karakhanyan, A., Rolland, Y., Melkonyan, R., Rebaï,
S., Davtyan, V., 2005. Neogene to Quaternary stress field evolution in Lesser Caucasus and adjacent regions using fault kinematics analysis and volcanic cluster data. Geodin. Acta 18, 401-416.

Avagyan, A., Sosson, M., Karakhanyan, A., Philip, H., Rebai, S., Rolland, Y., Melkonyan, R., Davtyan, V., 2010. Recent tectonic stress evolution in the Lesser Caucasus and adjacent regions. In: Sosson, M., Kaymakci, N., Stephenson, R.A., Bergerat, F., Starostenko, V. (Eds.), Sedimentary Basin Tectonics from the Black Sea and Caucasus to the Arabian Platform. 340. pp. 393-408 Geological Society, London, Special Publications.

Avagyan, A., Shahidi, A., Sosson, M., Sahakyan, L., Galoyan, G., Muller, C., Vardanyan, S., Firouzi, K.B., Bosch, D., Danelian, T., Asatryan, G., Mkrtchyan, M., Shokri, M.A., 2016. New data on the tectonic evolution of the Khoy region, NW Iran. In: Sosson, M., Stephenson, R.A., Adamia, S.A. (Eds.), Tectonic Evolution of the Eastern Black Sea and Caucasus. 428. pp. 99-116 Geological Society, London, Special Publications.

Avdeev, B., Niemi, N.A., 2011. Rapid Pliocene exhumation of the central Greater Caucasus constrained by low-temperature thermochronometry. Tectonics 30 , TC2009. https://doi.org/10.1029/2010TC002808.

Axen, G.J., Lam, P.S., Grove, M., Stockli, D.F., Hassanzadeh, J., 2001. Exhumation of the West-Central Alborz Mountains, Iran, Caspian subsidence, and collision-related tectonics. Geology 29, 559-562.

Azizbekov, S., 1972. Paleozoic. In: Azizbekov, S., Alizade, K., Shikhalibeili, E., Gajiev, T. (Eds.), Geology of the USSR. XLVII. Azerbaijan SSR, Geological Description, pp. 31-43.

Babayev, G., Ismail-Zadeh, A., Le Mouël, J.-L., 2010. Scenario-based earthquake hazard and risk assessment for Baku (Azerbaijan). Nat. Hazards Earth Syst. Sci. 10, 2697-2712.

Bagirov, E., Lerche, I., 1997. Hydrates represent gas source, drilling hazard. Oil Gas J. 1, 95-99 December 1997.

Balassanian, S., Ashirov, T., Chelidze, T., Gassanov, A., Kondorskaya, N., Molchan, G., Pustovitenko, B., Trifonov, V., Ulomov, V., Giardini, D., Erdik, M., Ghafory-Ashtiany, M., Grunthal, G., Mayer-Rosa, D., Schenk, V., Stucchi, M., 1999. Seismic hazard assessment for the Caucasus test area. Annali di Geofiz. 42 (6), 1139-1164.

Balavadze, B.K., Shengelaya, G.Sh., 1961. Main features the structure of the crust of the Greater Caucasus from gravity data. Doklady AN SSSR 136 (6), 131-140 (in Russian).

Barazangi, M., Sandvol, E., Seber, D., 2006. Structure and tectonic evolution of the Anatolian plateau in eastern Turkey. In: Dilek, Y., Pavlides, S. (Eds.), Postcollisional Tectonics and Magmatism in the Mediterranean Region and Asia. Geol. Soc. Am. Spec, Papers, pp. 409. https://doi.org/10.1130/2006.2409(22).

Barrier, E., Vrielynck, B., 2008. Atlas of Paleotectonic Maps of the Middle East (MEBE Program). Commission for the Geologic Map of the World, Paris.

Barrier, E., Vrielynck, B., Brouillet, J.-F., Brunet, M.-F., 2018. Paleotectonic Reconstruction of the Central Tethyan Realms. Tectonono-Sedimentary-Palinspastic Maps from Late Permian to Pliocene. Commission for the Geologic Map of the World, Paris.

Berberian, M., King, G.C.P., 1981. Towards a paleogeography and tectonic evolution of Iran. Can. J. Earth Sci. 18, 210-265.

Berberian, M., Yeats, R., 1999. Patterns of historical earthquake rupture in the Iranian Plateau. Bull. Seism. Soc. Amer. 89, 120-139.

Bonini, M., Rudolph, M.L., Manga, M., 2016. Long- and short-term triggering and modulation of mud volcano eruptions by earthquakes. Tectonophysics 672-673, 190-211.

Borisov, A.A., 1967. Deep Structure in the Territory of the USSR According to Geophysical Data. Nedra, Moscow (in Russian).

Brunet, M.F., Cloetingh, S., 2003. Intergrated Peri-Tethyan basins studies (Peri-Tethys programme). Sediment. Geol. 156, 1-10.

Brunet, M.-F., Korotaev, M.V., Ershov, A.V., Nikishin, A.M., 2003. The South Caspian Basin: a review of its evolution from subsidence modelling. Sediment. Geol. 156, 119-148.

CAC DRMI, 2009. Central Asia and Caucasus Disaster Risk Management Initiative: Risk Assessment for Central Asia and Caucasus. Desk Study Review, UNDRR, Geneva. Available at. https://www.unisdr.org/we/inform/publications/11641 (retrieved on 15.05.2019).

Cavazza, W., Albino, I., Zattin, M., Galoyan, G., Imamverdiyev, N., Melkonyan, R., 2017. Thermochronometric evidence for Miocene tectonic reactivation of the Sevan-Akera suture zone (Lesser Caucasus): a far-field tectonic effect of the Arabia-Eurasia collision? In: Sosson, M., Stephenson, R.A., Adamia, S.A. (Eds.), Tectonic Evolution of the Eastern Black Sea and Caucasus: Geological Society of London Special Publication. 428. pp. 187-198.

Cavazza, W., Cattò, S., Zattin, M., Okay, A.I., Reiners, P., 2018. The Miocene ArabiaEurasia collision zone of southeastern Turkey. Geosphere 14 (5), 2277-2293.

Cavazza, W., Albino, I., Galoyan, G., Zattin, M., Cattò, S., 2019. Continental accretion and incremental deformation in the thermochronologic evolution of the. Lesser Caucasus: Geoscience Frontiers 10 (6), 2189-2202.

Chelidze, T., 2018. New GPS and seismic data, position of the Main Trans-Caucasian fault and implications for seismic hazard. Bull. Georgian Nat. Acad. Sci. 12 (2), 85-89.

Cisternas, A., Philip, H., Bousquet, J.C., et al., 1989. The Spitak (Armenia) earthquake of 7 December 1988: field observations, seismology and tectonics. Nature 339, 675-679.

Cloetingh, S., Burov, E., 2011. Lithospheric folding and sedimentary basin evolution:a review and analysis of formation mechanisms. Basin Res. 23, 257-290.

Cochran, J.R., 1983. A model for development of Red Sea. AAPG Bull. 67, 41-69.

Console, R., Nardi, A., Carluccio, R., Murru, M., Falcone, G., Parsons, T., 2017. A physicsbased earthquake simulator and its application to seismic hazard assessment in Calabria (Southern Italy) region. Acta Geophys. 65, 243-257.

Copley, A., Jackson, J., 2006. Active tectonics of the Turkish-Iranian Plateau. Tectonics 25, TC6006. https://doi.org/10.1029/2005TC001906.

Cowgill, E., Forte, A.M., Niemi, N., Avdeev, B., Tye, A., Trexler, C., Javakhishvili, Z. 
Elashvili, M., Godoladze, T., 2016. Relict basin closure and crustal shortening budgets during continental collision: an example from Caucasus sediment provenance. Tectonics 35, 2918-2947.

Cowgill, E., Niemi, N.A., Forte, A.M., Trexler, C.C., 2018. Reply to comment by Vincent et al. Tectonics 37, 1017-1028.

Cutter, S., Ismail-Zadeh, A., Alcántara-Ayala, I., Altan, O., Baker, D.N., Briceño, S., Gupta, H., Holloway, A., Johnston, D., McBean, G.A., Ogawa, Y., Paton, D., Porio, E., Silbereisen, R.K., Takeuchi, K., Valsecchi, G.B., Vogel, C., Wu, G., 2015. Pool knowledge to stem losses from disasters. Nature 522, 277-279.

Danciu, L., Şeşetyan, K., Demircioglu, M., et al., 2018a. The 2014 Earthquake Model of the Middle East: seismogenic sources. Bull. Earthq. Eng. 16, 3465-3496.

Danciu, L., Kale, Ö., Akkar, S., 2018b. The 2014 earthquake model of the Middle East: ground motion model and uncertainties. Bull. Earthq. Eng. 16 (8), 3497-3533.

Dercourt, J., Zonenshain, L.P., Ricou, L.E., Kazmin, V.G., Le Pichon, X., Knipper, A.L., Grandjacqet, C., Sbortshikov, I.M., Geyssant, J., Lepvrier, C., Pechersky, D.M., Boulin, J., Sibuet, J.C., Savostin, L.A., Westphal, M., Bajenov, M.L., Lauer, J.P., Biju-Duval, B., 1986. Geological evolution of the Tethys belt from the Atlantic to the Pamirs since the Lias. Tectonophysics 123, 241-315.

Dewey, J.F., Pitman III, W.C., Ryan, W.B.F., Bonnin, J., 1973. Plate tectonics and the evolution of the Alpine system. Geol. Soc. Am. Bull. 84 (10), 3137-3180.

Dewey, J.F., Hempton, M.R., Kidd, W.S.F., Saroglu, F., Sengor, A.M.C., 1986. Shortening of continental lithosphere: the neotectonics of Eastern Anatolia - a young collision zone. In: Coward, M.P., Ries, A.C. (Eds.), Collision Tectonics. Geol. Soc. Lond. Spec. Publ. 9. pp. 3-36.

Dilek, Y., Imamverdiev, N., Altunkaynak, S., 2009. Geochemistry and tectonics of Cenozoic volcanism in the Lesser Caucasus (Azerbaijan) and the peri-Arabian region: collision-induced mantle dynamics and its magmatic fingerprint. Int. Geol. Rev. 52, 536-578.

Djamour, Y., Vernant, P., Bayer, R., Nankali, H.R., Ritz, J.F., Hinderer, J., Hatam, Y., Luck, B., Lemoigne, N., Sedighi, M., Khorrami, F., 2010. GPS and gravity constraints on continental deformation in the Alborz mountain range. Iran. Geophys. J. Int. 183, $1287-1301$.

Djamour, Y., Vernant, P., Nankali, H.R., Tavakoli, F., 2011. NW Iran-eastern Turkey present-day kinematics: results from the Iranian permanent GPS network. Earth Planet. Sci. Lett. 307 (1-2), 27-34.

Doglioni, C. Carminati, E. Cuffaro, M., Scrocca, D., 2007. Subduction kinematics and dynamic constraints. Earth Sci. Rev. 83 (3-4), 125-175.

Eppelbaum, L., Khesin, B., 2011. Development of 3-D gravity-magnetic models of Earth's crust of Azerbaijan and adjacent areas: a generalized review. Positioning 2 (2), 84-102.

Erdik, M., Seșetyan, K., Demircioglu, M.B., Tuzun, C., Giardini, D., Gulen, L., Akkar, S., Zare, M., 2012. Assessment of seismic hazard in the Middle East and Caucasus: EMME (Earthquake Model of Middle East) project. In: Proc. 15WCEE, 16, pp. 12371-12380. Ershov, A.V., Brunet, M.F., Nikishin, A.M., Bolotov, S.N., Nazarevich, B.P., Koroatev, M.V., 2003. Northern Caucasus basin: thermal history and synthesis of subsidence models. Sediment. Geol. 156, 95-118.

Förste, C., Bruinsma, S.L., Abrikosov, O., Lemoine, J.-M., Marty, J.C., Flechtner, F., Balmino, G., Barthelmes, F., Biancale, R., 2014. EIGEN-6C4 The latest combined global gravity field model including GOCE data up to degree and order 2190 of GFZ Potsdam and GRGS Toulouse. GFZ Data Services. https://doi.org/10.5880/icgem. 2015.1.

orte, A.M., Dziewonski, A.M., O'Connell, R.J., 1995. Thermal and chemical heterogeneity in the mantle: a seismic and geodynamic study of continental roots. Phys. Earth Planet. Inter. 92, 45-55.

Forte, A., Cowgill, E., Bernardin, T., Kreylos, O., Hamann, B., 2012. Late Cenozoic deformation of the Kura fold-thrust belt, southern Greater Caucasus. Geol. Soc. Am. Bull. 122 (3-4), 465-486.

Forte, A.M., Cowgill, E., Whipple, K.X., 2014. Transition from a singly vergent to doubly vergent wedge in a young orogen: The Greater Caucasus. Tectonics 33 (11), 2077-2101.

Fuenzalida, H., Rivera, L., Haessler, D., Legrand, D., Philip, H., Dorbath, L., McCormak, D., Arefiev, S., Langer, C., Cisternas, A., 1997. Seismic source study of the RachaDzhava (Georgia) earthquake from aftershocks and broad bank teleseismic bodywave records: an example of active nappe tectonics. Geophys. J. Int. 130, 29-46.

Galoyan, G., Rolland, Y., Sosson, M., Corsini, M., Melkonyan, R., 2007. Evidence for superposed MORB, oceanic plateau and volcanic arc series in the Lesser Caucasus (Stepanavan, Armenia). Compt. Rendus Geosci. 339 (7), 482-492.

Galoyan, G., Rolland, Y., Sosson, M., Corsini, M., Billoc, S., Verati, C., Melkonyan, R., 2009. Geology, geochemistry and 40Ar/39Ar dating of Sevan ophiolites (Lesser Caucasus, Armenia): evidence for Jurassic Back-arc opening and hot spot event between the South Armenian Block and Eurasia. J. Asian Earth Sci. 34 (2), 135-153.

Gamkrelidze, I., 1986. Geodynamic evolution of the Caucasus and adjacent areas in Alpine time. Tectonophysics 127, 261-277.

Gasanov, T.A., 1996. Evolution of the Sevan-Akera ophiolite zone, Lesser Caucasus. Geotectonics 20, 147-156.

Geodekyan, E.G., Sargsyan, G.V., 1987. Some Parameters of the Long-Term Seismic Regime of Armenia. Seismological Bulletin of Caucasus, Tbilisi, Metsinereba, In, pp. 114-122 (in Russian).

Ghonghadze, S.A., Chelidze, T.L., Mindeli, P.Sh., Ghlonti, N.I., Kiria, J.K., Yavolovskaya, O.V., 2016. Main sections of the earth crust and upper mantle of the Greater Caucasus by new technologies 2. Deep seismic sounding, micro seismic sounding. Geophysical J. (Geofizicheskiy zhurnal) 38 (4), 101-113 (in Russian).

Giardini, D., 1999. The Global Seismic Hazard Assessment Program (GSHAP) - 1992/ 1999. Ann. Geofis. 42 (6), 957-974.

Godoladze, T., Sandvol, E.A., Mackey, K.G., Nabelek, J., Tumanova, N., Yetermishli, G., Babayan, H., Malovichko, A., 2018. The Caucasus seismic network (CNET): Seismic structure of the Caucasus. Geophys. Res. Abstr. 20, EGU2018-19744.

Godzikovskaya, A., Reysner, G.I., 1989. Endogenic position of deep earthquakes in the Caucasus. Geotectonics 23, 205-213.

Gök, R., Sandvol, E., Turkelli, N., Seber, D., Barazangi, M., 2003. Snattenuation in the Anatolian and Iranian plateau and surrounding regions. Geophys. Res. Lett. 30 (24) https://doi.org/10.1029/2003GL018020.

Gök, R., Mellors, R.J., Sandvol, E., Pasyanos, M., Hauk, T., Takedatsu, R., Yetirmishli, G., Teoman, U., Turkelli, N., Godoladze, T., Javakishvirli, Z., 2011. Lithospheric velocity structure of the Anatolian plateau-Caucasus-Caspian region. J. Geophys. Res. 116, B05303. https://doi.org/10.1029/2009JB000837.

Gorshkov, A.I., Niauri, G.A., 1984. Reflection of fault tectonics of the Caucasus in zones of horizontal gravity anomaly gradients. Izv., Acad. Sci. USSR, Phys. of the Solid Earth 20 (9), 699-704 (in Russian).

Gorshkov, A.I., Zhidkov, M.P., Rantsman, E.Y., Tumarkin, A.G., 1991. Morphostructures of the Lesser Caucasus and sites of earthquakes $M \geq 5.5$. Izv. Akademii Nauk SSSR Fizika Zemli 28 (6), 30-38 (in Russian).

Gorshkov, A., Kossobokov, V., Soloviev, A., 2003. Recognition of earthquake-prone areas. In: Keilis-Borok, V.I., Soloviev, A.A. (Eds.), Nonlinear Dynamics of the Lithosphere and Earthquake Prediction. Springer, Heidelberg, pp. 239-310.

Griffin, W.L., O'Reilly, S.Y., Ryan, C.G., Gaul, O., Ionov, D.A., 1998. Secular variation in the composition of subcontinental lithospheric mantle: geophysical and geodynamic implications. In: Braun, J. (Ed.), Structure and Evolution of the Australian Continent Am. Geophys. Union, Geodyn. Ser. 26, pp. 1-26.

Guliyev, I.S., Panahi, B.M., 2004. Geodynamics of the deep sedimentary basin of the Caspian Sea region: paragenetic correlation of seismicity and mud volcanism. GeoMar. Lett. 24 (3), 169-176.

Gvishiani, A., Gorshkov, A.I., Rantsman, E.Y., Cisternas, A., Soloviev, A.A., 1988. Recognition of Earthquake-Prone Sites in Moderate Seismicity Regions. Nauka, Moscow (in Russian).

Hall, R., 1976. Ophiolite emplacement and the evolution of the Taurus suture zone, southeastern Turkey. Geol. Soc. Am. Bull. 87, 1078-1088.

Hartley, R.V.L., 1942. A more symmetric Fourier analysis applied to transmission problems. Proc. IRE 30 (2), 144-150.

Hässig, M., Rolland, Y., Sosson, M., Galoyan, G., Sahakyan, L., Topuz, G., Faruk Çelik, Ö., Avagyan, A., Müller, C., 2013. Linking the NE Anatolian and Lesser Caucasus ophiolites: evidence for large-scale obduction of oceanic crust and implications for the formation of the Lesser Caucasus-Pontides Arc. Geodin. Acta 26 (3-4), 311-330.

Hässig, M., Duretz, T., Rolland, Y., Sosson, M., 2016. Obduction of old oceanic lithosphere in NE Anatolia - Lesser Caucasus: insights from numerical modelling. J. Geodyn. 96, $35-49$.

Hässig, M., Rolland, Y., Sosson, M., 2017. From ocean crust genesis to obduction initiation: history of the northern branch of Neotethys prior to the Late Cretaceous obduction event in the NE Anatolian and Lesser Caucasus regions. In: Sosson, M., Stephenson, R.A., Adamia, S.A. (Eds.), Tectonic Evolution of the Eastern Black Sea and Caucasus. Geological Society, London, Special Publications, 428, pp. 41-60.

Ismail-Zadeh, A.T., 1996. Migration of seismic activity in the Caspian Sea. In: Comput. Seism. Geodyn., 3, 125-129, Amer. Geophys. Union, Washington D.C, https://doi. org/10.1029/CS003p0125.

Ismail-Zadeh, T., 2006. Peculiarity of seismicity in the Balakend-Zagatal region, Azerbaijan. In: Ismail-Zadeh, A. (Ed.), Recent Geodynamics. Georisk and Sustainable Development in the Black Sea to Caspian Sea Region, AIP Conference Proceedings 825. pp. 103-106.

Ismail-Zadeh, A., 2014. Extreme seismic events: from basic science to disaster risk mitigation. In: Ismail-Zadeh, A., Urrutia Fucugauchi, J., Kijko, A., Takeuchi, K., Zaliapin, I. (Eds.), Extreme Natural Hazards, Disaster Risks and Societal Implications. Cambridge University Press, Cambridge, pp. 47-60.

Ismail-Zadeh, A., 2018. Earthquake hazard modelling and forecasting for disaster risk reduction. In: Vacareanu, R., Ionescu, C. (Eds.), Seismic Hazard and Risk Assessment. Springer Natural Hazards, Springer, Cham, pp. 3-21.

Ismail-Zadeh, A.T., Naimark, B.M., Kostyuchenko, S.L., 1997. Quantitative modelling of the Tunguska Basin evolution in the Palaeozoic: a role of eclogitization within the uppermost mantle. J. Geodyn. 23, 47-63.

Ismail-Zadeh, A.T., Le Mouël, J.-L., Soloviev, A., Tapponnier, P., Vorobieva, I., 2007. Numerical modelling of crustal block-and-fault dynamics, earthquakes and slip rates in the Tibet-Himalayan region. Earth Planet. Sci. Lett. 258, 465-485.

Ismail-Zadeh, A., Matenco, L., Radulian, M., Cloetingh, S., Panza, G., 2012. Geodynamic and intermediate-depth seismicity in Vrancea (the south-eastern Carpathians): Current state-of-the-art. Tectonophysics 530-531, 50-79.

Ismail-Zadeh, A., Cutter, S.L., Takeuchi, K., Paton, D., 2017. Forging a paradigm shift in disaster science. Nat. Hazards 86 (2), 969-988.

Ismail-Zadeh, A., Soloviev, A., Sokolov, V., Vorobieva, I., Muller, B., Schilling, F., 2018. Quantitative modeling of the lithosphere dynamics, earthquakes and seismic hazard. Tectonophysics 746, 624-647.

Jackson, J., 1992. Partitioning of strike-slip and convergent motion between Eurasia and Arabia in eastern Turkey. J. Geophys. Res. 97, 12471-12479.

Jackson, J., Ambraseys, N., 1997. Convergence between Eurasia and Arabia in eastern Turkey and the Caucasus. In: Giardini, D., Balassanian, S. (Eds.), Historical and Prehistorical Earthquakes in the Caucasus. Kluwer Academic Publishers, Dordrecht, pp. 79-90.

Jackson, J., McKenzie, D., 1984. Active tectonics of the Alpine-Himalayan belt between western Turkey and Pakistan. Geophys. Jour. R. Astr. Soc. 77, 185-246.

Jackson, J., McKenzie, D., 1988. The relationship between plate motions and seismic tremors, and the rates of active deformation in the Mediterranean and Middle East. Geophys. Jour. R. Astr. Soc. 93, 45-73.

Jackson, J., Priestley, K., Allen, M., Berberian, M., 2002. Active tectonics of the South Caspian Basin. Geophys. J. Int. 148 (2), 214-245. 
Jolivet, L., Faccenna, C., 2000. Mediterranean extension and the Africa-Eurasia collision. Tectonics 19, 1095-1106.

Joyner, W.B., 1967. Basalt-eclogite transition as a cause for subsidence and uplift. J. Geophys. Res. 72, 4977-4998.

Kaban, M.K., Mooney, W.D., Petrunin, A.G., 2015. Cratonic root beneath North America shifted by basal drag from the convecting mantle. Nat. Geosci. 8 (10), 797-800.

Kaban, M.K., El Khrepy, S., Al-Arifi, N., Tesauro, M., Stolk, W., 2016. Three-dimensional density model of the upper mantle in the Middle East: Interaction of diverse tectonic processes. J. Geophys. Res. Solid Earth 121. https://doi.org/10.1002/ 2015JB012755.

Kaban, M.K., Petrunin, A.G., El Khrepy, S., Al-Arifi, N., 2018. Diverse continental subduction scenarios along the Arabia-Eurasia collision zone. Geophys. Res. Lett. 45 (14), 6898-6906.

Kadirov, F.A., 2000. Gravity Field and Models of Deep Structure of Azerbaijan. Baku, Geology Institute of the Azerbaijan National Academy of Sciences (in Russian).

Kadirov, F.A., 2004. Gravity models of lithosphere in the Caucasus - Caspian region. In: Alizade, Ak.A. (Ed.), South Caspian Basin: Geology, Geophysics, Oil and Gas Content. Nafta-Press, Baku, pp. 107-122.

Kadirov, F.A., Gadirov, A.H., 2014. A gravity model of the deep structure of South Caspian Basin along submeridional profile Alborz-Absheron Sill. Glob. Planet. Chang. $114,66-74$.

Kadirov, F., Mammadov, S., Reilinger, R.E., McClusky, S., 2008. Some new data on modern tectonic deformation and active faulting in Azerbaijan (according to Global Positioning System measurements). Proc. Azerbaijan Nat. Acad. Sci., Sciences of the Earth 1, 82-88.

Kadirov, F., Floyd, M., Alizadeh, A., Guliev, I., Reilinger, R.E., Kuleli, S., King, R., Toksoz, M.N., 2012. Kinematics of the eastern Caucasus near Baku. Azerbaijan. Nat. Haz. 63 (2), 997-1006.

Kadirov, F.A., Floyd, M., Reilinger, R., Alizadeh, A.A., Guliyev, I.S., Mammadov, S.G., Safarov, R. T. 2015. Active geodynamics of the Caucasus region: Implication for earthquake hazards in Azerbaijan. Proc. Azerbaijan Nat. Acad. Sci., Earth Sciences 3, 3-17.

Kagan, Y.Y., 2002. Seismic moment distribution revisited: II. Moment conservation principle. Geophys. J. Int. 149 (3), 731-754.

Karakhanyan, A., Vernant, P., Doerflinger, E., et al., 2013. GPS constraints on continental deformation in the Armenian region and Lesser Caucasus. Tectonophysics 592, $39-45$.

Karakhanyan, A., Arakelyan, A., Avagyan, A., Sadoyan, T., 2017. Aspects of the seismotectonics of Armenia: New data and reanalysis. Tectonic evolution, collision, and seismicity of Southwest Asia In: Sorkhabi, R. (Ed.), Honor of Manuel Berberian's Forty-Five Years of Research Contributions: Geological Society of America Special Paper 525, pp. 445-477.

Karapetyan, N.K., 1973. Spectral Characteristics of Seismic Waves in Armenia. Armenian Academy of Sciences, Yerevan 275 p. (in Russian)

Karapetyan, N.K., 1986. Mechanism of Earthquake Ruptures in the Armenian Highlands. Armenian Academy of Sciences, Yerevan 228 p. (in Russian).

Karato, S.-I., 1993. Importance of anelasticity in the interpretation of seismic tomography. Geophys. Res. Lett. 20, 1623-1626.

Karato, S.-I., 2003. Mapping water content in the upper mantle. In: Eiler, J. (Ed.) Inside the Subduction Factory. Am. Geophys. Union. Geophys. Monogr. 138, 135-150.

erimov, K.M., Pilchin, A.N., Gadjiev, T.G., Buachidze, G.Y., 1989. Geothermal map of the Caucasus, Scale 1:1,000,000. Baku, Cartographic Plant No. 11.

Khain, V.Y., 1975. Structure and main stages in the tectono-magmatic development of the Caucasus: An attempt at geodynamic interpretation. Am. J. Sci. A275, 131-156.

Khain, V.Y., Lobkovsky, L.I., 1994. Relict seismicity in the Alpine belt of Eurasia: mode of occurrence. Geotectonics 28, 192-198.

Khalilov, E., Mekhtiyev, S., Khain, V.Y., 1987. Some geophysical data confirming the collisional origin of the Greater Caucasus. Geotectonics 21, 132-136.

Knapp, C.C., Knapp, J.H., Connor, J.A., 2004. Crustalscale structure of the South Caspian Basin revealed by deep seismic reflection profiling. Mar. Pet. Geol. 2, 1073-1081.

Knipper, A., 1975. The Oceanic Crust in the structure of the Alpine folded areas. In: Proc. Geol. Inst. USSR Acad. Sci., No. 267, Moscow, Nauka, 193 p. (in Russian).

Knipper, A., 1991. Upper Triassic-Early Jurassic sedimentary breccias in the ophiolite suture of the Lesser Caucasus. In: Peters, T.J., Nicolas, A., Coleman, R. (Eds.), Ophiolite Genesis and Evolution of the Oceanic Lithosphere. Ministry of Petroleum and Minerals, Sultanate of Oman, pp. 705-713.

Knipper, A.L., Ricou, L.-E., Dercourt, J., 1987. Ophiolites as an index-Factor of geodynamic evolution of the Tethys Ocean. In: Monin, A.S., Zonenshain, L.P. (Eds.), The Evolution of the Tethys Ocean: Moscow, P.P. Shirshov Institute of Oceanology, Academy of the USSR, pp. 94-104.

Koçyiğgit, A., Yilmaz, A., Adamia, Sh., Kuloshvili, S., 2001. Neotectonics of East Anatolian plateau (Turkey) and Lesser Caucasus: implication for transition from thrusting to strike-slip faulting. Geodyn. Acta 14, 177-195.

Kondorskaya, N.V., Shebalin, N.V., 1977. New Catalog of Strong Earthquakes in the U.S.S.R. from Ancient Times Through 1975. Moscow, Nauka.

Kopp, M.L., Shcherba, I.G., 1985. Late Alpine development of the Eastern Caucasus. Geotectonics 19 (6), 497-507 (in Russian).

Koulakov, I., Zabelina, I., Amanatashvili, I., Meskhia, V., 2012. Nature of orogenesis and volcanism in the Caucasus region based on results of regional tomography. Solid Earth 3 (2), 327-337.

Kovachev, S.A., Kaz'min, V.G., Kuzin, I.P., Lobkovsky, L.I., 2006. New data on seismicity of the Middle Caspian Basin and their possible tectonic interpretation. Geotectonics 40 (5), 367-376.

Kovalenko, V., Yarmolyuk, V., Bogatikov, O., 2008. Recent volcanism of North Eurasia: evolution trends, volcanic hazard, relationship to deep processes and change in the environment and climate. In: Change of the Environment and Climate: Natural and
Related Technogenic Catastrophes. IGEM RAS and IFZ RAS, Moscow, pp. 13-230 (in Russian).

Král, J., Gurbanov, A.G., 1996. Apatite fission track data from the Greater Caucasus preAlpine basement. Chem. Erde 56, 177-192.

Krasnopevtseva, G.V., Matushkin, B.A., Shevchenko, V.I., 1970. New NHS interpretation of the data on the profile of the Steppe-Bakuriani in the Caucasus. Soviet Geol. 8 , 113-120 (in Russian).

Kutas, R.I., Poort, J., 2008. Regional and local conditions in the northern Black Sea. Int. J. Earth Sci. 97, 353-363.

Kutas, R.I., Liubimova, E.A., Smirnov, Ya.B., 1978. A heat flow map of European part of the USSR. Pure Appl. Geophys. 117 (1-2), 104-108.

Lawrence, S.A., 2003. Kinematically consistent, elastic block model of the Eastern Mediterranean constrained by GPS measurements. M.S. Thesis, Massachusetts Institute of Technology, Cambridge, MA.

Lodzhevsky, M.I., Kadirov, F.A., 2001. Caspian Region: Bouguer Gravimetry Map. In: Scale 1:1,000,000. Russia \& Geology Institute of the Azerbaijan National Academy of Sciences, Fedynsky Centre GEON, Moscow.

Lordkipanidze, M.B., Meliksetian, B., Djarbashian, R., 1989. Mesozoic-Cenozoic mag matic evolution of the Pontian-Crimean-Caucasian region. In: Rakuš, M., Dercourt, J., Nairn, A.E.M. (Eds.), IGCP Project no 198: Evolution of the Northern Margin of the Tethys. Mémoires de la Société Géologique de France (Paris, Nouvelle Série), 154, pp. 103-124.

Luth, S., Willingshofer, E., Sokoutis, D., Cloetingh, S., 2010. Analogue modelling of continental collision: influence of plate coupling on mantle lithosphere subduction, crustal deformation and surface topography. Tectonophysics 484, 87-102.

Maggi, A., Priestley, K., 2005. Surface waveform tomography of the Turkish-Iranian plateau. Geophys. J. Int. 160 (3), 1068-1080.

Main, I., 1996. Statistical physics, seismogenesis, and seismic hazard. Rev. Geophys. 34 (4), 433-462.

Mangino, S., Priestly, K., 1998. The crustal structure of the southern Caspian region. Geophys. J. Int. 133, 630-648.

Map, Gravity, 1990. Gravity Map of the USSR, Scale 1:2500000. Moscow, USSR Minister of Geology.

Martin, R.J., O'Connor, T., Adamia, S., Szymanski, E., Krasovec, M., 2012. BorjomiKazbegi Fault: Does it Exist? American Geophysical Union, Fall Meeting 2012, Abstracts, S44C-07.

McCann, T., Chalot-Prat, F., Saintot, A., 2010. The Early Mesozoic evolution of the Western Greater Caucasus (Russia): Triassic-Jurassic sedimentary and magmatic history. Geol. Soc. Lond., Spec. Publ. 340, 181-238.

McClusky, S., Balassanian, S., Barka, A., Demir, C., Ergintav, S., Georgiev, I., Gurkan, O., Hamburger, M., Hurst, K., Kahle, H., Kastens, K., Kekelidze, G., King, R., Kotzev, V., Lenk, O., Mahmoud, S., Mishin, A., Nadaraia, M., Ouzounis, A., Paradissis, D., Peter, Y., Prilepin, M., Reilinger, R., Sanli, I., Seeger, H., Tealeb, A., Toksoz, M., Veis, G., 2000. Global positioning system constraints on plate kinematics and dynamics in the eastern Mediterranean and Caucasus. J. Geophys. Res. 105 (B3), 5695-5719.

McKenzie, D.P., 1970. Plate tectonics of the Mediterranean region. Nature 226, 239-243.

McKenzie, D., 1972. Active tectonics of the Mediterranean region. Geophys. J. R. Astron. Soc. 30, 109-185.

McQuarrie, N., van Hinsbergen, D.J.J., 2013. Retro deforming the Arabia-Eurasia collision zone: Age of collision versus magnitude of continental subduction. Geology 41 , 315-318.

Mederer, J., Moritz, R., Ulianov, A., Chiaradia, M., 2013. Middle Jurassic to Cenozoic evolution of arc magmatism during Neotethys subduction and arc-continent collision in the Kaphan zone, southern Armenia. Lithos 177, 61-78.

Meijers, M., Smith, B., Pastor-Galan, D., Degenaar, R., Sadradze, N., Adamia, S. Sahakyan, L., Avagyan, A., Sosson, M., Rolland, Y., Langereis, C.G., Muller, C., 2015. Progressive orocline formation in the Eastern Pontides-Lesser Caucasus. In: Sosson, M., Stephenson, R., Adamia, S. (Eds.), Tectonic Evolution of the Eastern Black Sea and the Caucasus. Geol. Soc. London Spec. Publ. 428. pp. 117-145.

Mellors, R.J., Jackson, J., Myers, S., Gok, R., Priestley, K., Yetirmishli, G., Turkelli, N., Godoladze, T., 2012. Deep earthquakes beneath the northern Caucasus: evidence of active or recent subduction in western Asia. Bull. Seismol. Soc. Am. 102 (2), 862-866.

Mitchell, J., Westaway, R., 1999. Chronology of Neogene and Quaternary uplift and magmatism in the Caucasus: constraints from $\mathrm{K}$ Ar dating of volcanism in Armenia. Tectonophysics 304 (3), 157-186.

Mogi, K., 1968. Migration of seismic activity. Bull. Earth. Res. Inst. 46, 53-74.

Mosar, J., Kangarli, T., Bochud, M., et al., 2010. Cenozoic-recent tectonics and uplift in the Greater Caucasus: a perspective from Azerbaijan. In: Sosson, M., Kaymakci, N. Stephenson, R., Bergerat, F., Starostenko, V. (Eds.), Sedimentary Basin Tectonics from the Black Sea and Caucasus to the Arabian Platform, vol. 3. Geol. Soc. London Spec. Publ. 340. pp. 261-280.

Mumladze, T., Forte, A.M., Cowgill, E.S., Trexler, C.C., Niemi, N.A., Yıkılmaz, M.B., Kellogg, L.H., 2015. Subducted, detached, and torn slabs beneath the Greater Caucasus. GeoResJ 5, 36-46.

Mustafaev, M.A., 2000. Mesozoic volcanism in Azerbaijan and paleo-geodynamic conditions of its formation. Proc. Azerbaijan Nat. Acad. Sci., Earth Sci. 11, 27-33 (in Russian).

Mustafaev, M.A., 2003. Early Jurassic volcanism in the Greater Caucasus. Proc Azerbaijan Nat. Acad. Sci., Earth Sci. 1, 40-49 (in Russian).

Nemčok, M., Glonti, B., Yukler, A., Marton, B., 2013. Development history of the foreland plate trapped between two converging orogens; Kura Valley, Georgia, case study. In: Nemčok, M., Mora, A., Cosgrove, J.W. (Eds.), Thick-Skin-Dominated Orogens: From Initial Inversion to Full Accretion. Geol. Soc. London, Spec. Publ. 377. pp. 1-31.

Neprochonov, Y.P., Kosminskaya, I.P., Malovitsky, Y.P., 1970. Structure of the crust and upper mantle of the Black and Caspian seas. Tectonophysics 10, 517-538. 
Novikova, O.V., Gorshkov, A.I., 2018. High seismicity intersections of morphostructural lineaments: The Black-Sea - Caspian Region. J. Volcanol. Seismol. 12 (6), 378-385. https://doi.org/10.1134/S0742046318060064.

O'Connor, T., Szymanski, E., Krasovec, M., Adamia, S., 2006. Rethinking the tectonic model of the Caucasus: An investigation of the southern section of the proposed Borjomi-Kazbegi Fault. EGU Geophys. Res. Abst. 8, 09746.

Okada, Y., 1985. Surface deformation due to shear and tensile faults in a half-space. Bull. Seismol. Soc. Am. 75, 1135-1154.

Okay, A., Şahintürk, Ő., 1997. Geology of the Eastern Pontides. In: Robinson, A.G. (Ed.), Regional and Petroleum Geology of the Black Sea and Surrounding Region. AAPG Memoir 68. pp. 291-313.

Okay, A.I., Zattin, M., Cavazza, W., 2010. Apatite fission-track data for the Miocene Arabia-Eurasia collision. Geology 38, 35-38.

Pagani, M., Monelli, D., Weatherill, G., Danciu, L., Crowley, H., Silva, V., Henshaw, P., Butler, L., Nastasi, M., Panzeri, L., Simionato, M., Vigano, D., 2014. OpenQuake engine: an open hazard (and risk) software for the global earthquake model. Seismol. Res. Lett. 85, 692-702.

Panahi, B.M., 2006. Seismicity in Azerbaijan and adjacent Caspian Sea. In: Ismail-Zadeh, A. (Ed.), Recent Geodynamics. Georisk and Sustainable Development in the Black Sea to Caspian Sea Region, AIP Conference Proceedings 825. pp. 3-10.

Pavlenkova, G.A., 2012. Crustal structure of the Caucasus from the Stepnoe-Bakuriani and Volgograd-Nakhchivan DSS profiles (reinterpretation of the primary data). Izvestiya. Physics of the Solid Earth 48 (5), 375-384.

Philip, H., Cisternas, A., Gvishiani, A., Gorshkov, A., 1989. The Caucasus: an actual example of the initial stages of continental collision. Tectonophysics 161, 1-21.

Pliny the Elder, 1855. The Natural History, volume 2, book 6, chapter 19; the original text published in 77-79 AD was translated by J. Bostock and H.T. Riley.

Pollack, H., Chapman, D., 1977. On the regional variations of heat flow, geotherms and lithosphere thickness. Tectonophysics 38, 279-296.

Rebai, S., Philip, H., Dorbath, L., Borisoff, B., Haessler, H., Cisternas, A., 1993. Active tectonics in the Lesser Caucasus: coexistence of compressive and extensional structures. Tectonics 12 (5), 1089-1114.

Reilinger, R.E., McClusky, S., Vernant, P., Lawrence, S., Ergintav, S., Cakmak, R., Ozener, H., Kadirov, F., Guliev, I., Stepanyan, R., Nadariya, M., Hahubia, G., Mahmoud, S., Sakr, K., Arrajehi, A., Paradissis, D., Al-Aydrus, A., Prilepin, M., Guseva, T., Evren, E., Dmitrotsa, A., Filikov, S.V., Gomez, F., Al-Ghazzi, R., Karam, G., 2006. GPS constraints on continental deformation in the Africa-Arabia-Eurasia continental collision zone and implications for the dynamics of plate interactions. J. Geophys. Res., BO5411. https://doi.org/10.1029/2005JB004051.

Robertson, A.H.F., Parlak, O., Rizaoğlu, T., Ünlügenç, Ü., Inan, N., Tasli, K., Ustaömer, T., 2007. Tectonic evolution of the south Tethyan ocean: evidence from the eastern Taurus Mountains (Elazığ region, SE Turkey). In: Ries, A.C., Butler, R.W.H., Graham, R.H. (Eds.), Deformation of Continental Crust. Geol. Soc. London, Spec. Publ, pp. 231-270 272

Rogozhin, E.A., Bogachkin, B.M., Nechayev, Y.V., 1993. Seismotectonic meaning of transversal zoning in the north-western Greater Caucasus, in: Construction of Development Models of Seismic Process. United Institute of the Physics of the Earth, Moscow, pp. 139-148 (in Russian).

Saakyan, A.A., Geodekyan, E.G., Sargsyan, G.V., 1983. Results of the application of average regional travel-time curve to the Armenian Highlands. Izv. Armenian Acad. Sci. Earth Sci. 6, 80-85 (in Russian).

Sahakyan, I., Bosch, D., Sosson, M., Avagyan, A., Galoyan, Gh., Rolland, Y., Bruguer, O., Stepanyan, Zh., Galland, B., Vardanyan, S., 2017. Geochemistry of the Eocene

magmatic rocks from the Lesser Caucasus area (Armenia): evidence of a subduction geodynamic environment. In: Sosson, M., Stephenson, R., Adamia, S. (Eds.), Teconic Evolution of the Eastern Black Sea and Caucasus. Geol. Soc. London Spec. Publ. 428. pp. 73-99.

Saintot, A., Angelier, J., 2002. Tectonic paleostress fields and structural evolution of the NW-Caucasus fold-and-thrust belt from Late Cretaceous to Quaternary. Tectonophysics. 357 (1-4), 1-31.

Saintot, A., Brunet, M.F., Yakovlev, F., Sebrier, M., Stephenson, R., Ershov, A., ChalotPrat, F., McCann, T., 2006. The Mesozoic-Cenozoic tectonic evolution of the Greater Caucasus. Geol. Soc. Lond. Mem. 32, 277-289.

Schaeffer, A.J., Lebedev, S., 2013. Global shear-speed structure of the upper mantle and transition zone. Geophys. J. Int. 194 (1), 417-449.

Şengör, A.M.C., Kidd, W.S.F., 1979. Post-collisional tectonics of the Turkish-Iranian plateau and a comparison with Tibet. Tectonophysics 55, 361-376.

Sengor, A.M.C., Gorur, N., Saroglu, F., 1985. Strike-slip faulting and related basin formation in zones of tectonic escape: Turkey as a case study. In: Biddle, K.T., ChristieBlick, N. (Eds.), Strike-slip Faulting and Basin Formation. Society of Econ. Paleont. Min. Sec. Publ 37. pp. 227-264.

Şengor, A.M.C., Tuysuz, O., Imren, C., Sakinc, M., Eyidogan, H., Gorur, N., LePichon, X., Rangin, C., 2004. The North Anatolian fault: A new look. Annu. Rev. Earth Planet Sci. 33, 1-75.

Şeşetyan, K., Danciu, L., Demircioğlu Tümsa, M.B., et al., 2018. The 2014 seismic hazard model of the Middle East: overview and results. Bull. Earthq. Eng. 16 (8), 3535-3566.

Shengelaya, G.S., 1984. Gravity Model of the Earth Crust of the Caucasus. Nauka, Moscow (in Russian).

Shikhalibeili, E.S., 1996. Some Problems of Geologic Structure and Tectonics in Azerbaijan. Baku, Elm (in Russian).

Sholpo, V.N., 1978. Alpine Geodynamics of the Greater Caucasus. Nedra, Moscow (in Russian).

Skobeltsyn, G., Mellors, R., Gök, R., Türkelli, N., Yetirmishli, G., Sandvol, E., 2014. Upper mantle S wave velocity structure of the East Anatolian-Caucasus region. Tectonics 33, 207-221.

Smit, J.H.V., Cloetingh, S.A.P.L., Burov, E., Tesauro, M., Sokoutis, D., Kaban, M., 2013.
Interference of lithospheric folding in western Central Asia by simultaneous Indian and Arabian plate indentation. Tectonophysics 602, 176-193.

Sokhadze, G., Floyd, M., Godoladze, T., King R., Cowgill, E. S., Javakhishvili, Z, Hahubia, G., Reilinger, R., 2018. Active convergence between the Lesser and Greater Caucasus in Georgia: Constraints on the tectonic evolution of the Lesser-Greater Caucasus continental collision. Earth Planet. Sci. Lett. 481, 154-161.

Sokolov, S., 1977. Olistostromes and ophiolitic nappes of the Lesser Caucasus. In: Proc. Geol. Inst. USSR Acad. Sci., No. 296, Moscow, Nauka, 94 p. (in Russian).

Sokolov, V., Ismail-Zadeh, A., 2015. Seismic hazard from instrumentally recorded, historical and simulated earthquakes: application to the Tibet-Himalayan region. Tectonophysics 657, 187-204.

Sokolov, V., Ismail-Zadeh, A., 2016. On the use of multiple-site estimations in probabilistic seismic hazard assessment. Bull. Seismol. Soc. Am. 106 (5), 2233-2243.

Soloviev, A.A., Gorshkov, A.I., 2017. Modeling the dynamics of the block structure and seismicity of the Caucasus. Izv. Phys. Solid Earth 53 (3), 321-331.

Soloviev, A., Ismail-Zadeh, A., 2003. Models of dynamics of block-and-fault systems. In: Keilis-Borok, V.I., Soloviev, A.A. (Eds.), Nonlinear Dynamics of the Lithosphere and Earthquake Prediction. Springer, Heidelberg, pp. 71-138.

Soloviev, A.A., Novikova, O.V., Gorshkov, A.I., Piotrovskaya, E.P., 2013. Recognition of potential sources of strong earthquakes in the Caucasus region using GIS technologies. Dokl. Earth Sci. 450 (2), 658-660.

Soloviev, A.A., Gorshkov, A.I., Soloviev, A.A., 2016. Application of the data on the lithospheric magnetic anomalies in the problem of recognizing the earthquake prone areas. Izv., Phys. Solid Earth 52 (6), 803-809.

Sosson, M., Kaymakci, N., Stephenson, R., Bergerat, F., Starostenko, V., 2010a. Sedimentary basin tectonics from the Black Sea and Caucasus to the Arabian Platform: introduction. In: Sosson, M., Kaymakci, N., Stephenson, R.A., Bergerat, F., Starostenko, V. (Eds.), Sedimentary Basin Tectonics from the Black Sea and Caucasus to the Arabian Platform. Geol. Soc. London Spec. Publ. 340. pp. 1-10.

Sosson, M., Rolland, Y., Danelian, T., Muller, C., Melkonya, R., Adamia, S., Kangarli, A., Galoyan, G., 2010b. Subductions, obduction and collision in the Lesser Caucasus (Armenia, Azerbaijan, Georgia), new insights. In: Sosson, M., Kaymakci, N., Stephenson, R.A., Bergerat, F., Starostenko, V. (Eds.), Sedimentary Basin Tectonics from the Black Sea and Caucasus to the Arabian Platform. Geol. Soc. London Spec Publ. 340. pp. 329-352.

Sosson, M., Stephenson, R., Sheremet, Y., Rolland, Y., Adamia, S., Melkonian, R., Kangarli, T., Yegorova, T., Avagyan, A., Galoyan, G., Danelian, T., Hässig, M., Meijers, M., Müller, C., Sahakyan, L., Sadradze, N., Alania, V., Enukidze, O., Mosar, J., 2016. The eastern Black Sea-Caucasus region during the Cretaceous: new evidence to constrain its tectonic evolution. C. R. Geoscience 348, 23-32.

Sosson, M., Stephenson, R.A., Adamia, S.A. (Eds.), 2017. Tectonic Evolution of the Eastern Black Sea and Caucasus. Geol. Soc. London, Spec. Publ, https://doi.org/10. 1144/SP428. 428.

Sosson, M., Stephenson, R., Adamia, S., Avagyan, A., Kangarli, T., Starostenko, V., Yegorova, T., Sheremet, Y., Barrier, E., Rolland, Y., Hässig, M., Candaux, Z., Alania, V., Enukidze, O., Sadradze, N., Sahakyan, L., Galoyan, G., Vardanyan, S., 2019. The Eastern Black Sea and Caucasus domain origin and its tectonic evolution: new insights from results of a decade of field works and of geophysical research. In: Rossetti, F., Blanc, A.C., Riguzzi, F., Leroux, E., Pavlopoulos, K., Bellier, O., Kapsimalis, V. (Eds.), The Structural Geology Contribution to the Africa-Eurasia Geology: Basement and Reservoir Structure, Ore Mineralisation and Tectonic Modelling. CAJG 2019. Advances in Science, Technology \& Innovation (IEREK Interdisciplinary Series for Sustainable Development). Springer, Cham.

Stampfli, G., 2000. Tethyan oceans. In: Bozkurt, E., Winchester, J., Piper, J. (Eds.), Tectonics and Magmatism in Turkey and the Surrounding Area, Geol. Soc. London, Spec. Publ. 173. pp. 1-23.

Stampfli, G.M., Borel, G.D., Cavazza, W., Mosar, J., Ziegler, P.A., 2001. Palaeotectonic and palaeogeographic evolution of the western Tethys and Peri-Tethyan domain (IGCP Project 369). Episodes 24, 222-228.

Starostenko, V.I., Dolmaz, M.N., Kutas, R.I., Rusakov, O.M., Oksum, E., Hisarli, Z.M., Okyar, M., Kalyoncuoglu, U.Y., Tutunsatar, H.E., Legostaeva, O.V., 2014. Thermal structure of the crust in the Black Sea: comparative analysis of magnetic and heat flow data. Mar. Geophys. Res. 35, 345-359.

Tan, O., Taymaz, T. 2006. Active tectonics of the Caucasus: Earthquake source mechanisms and rupture histories obtained from inversion of teleseismic body waveforms. In: Dilek, Y., Pavlides, S. (Eds.), Postcollisional Tectonics and Magmatism in the Mediterranean Region and Asia. Geol. Soc. Amer. Spec. Paper 409. pp. 531-578.

Tesauro, M., Kaban, M., Cloetingh, S., 2009. A new thermal and rheological model of the European lithosphere. Tectonophysics 476 (3-4), 478-495.

Tesauro, M., Kaban, M., Cloetingh, S., 2010. 3D crustal model of Western and Central Europe as a basis for modeling mantle structure. In: Cloetingh, S., Negendank, J.F. (Eds.), New Frontiers in Integrated Solid Earth Sciences. Springer, Berlin-Heidelberg, pp. 39-69.

The New York Times, 1902a. 2000 dead at Shamakha. 12 February.

The New York Times, 1902b. The Shamakha earthquake. 15 March.

Triep, E.G., Abers, G.A., Lerner-Lam, A.L., Mishatkin, V., Zakharchenko, N., Starovoit, O., 1995. Active thrust front of the Greater Caucasus: The April 29, 1991, Racha earthquake sequence and its tectonic implications. J. Geophys. Res. 100, 4011-4033.

Trifonov, V.G., Karakhanyan, A.S., Kozhurin, A.J., 1994. Active faults of the collision area between the Arabian and the Eurasian plates. Proc. of the Conference on Continental Collision Zone Earthquakes and Seismic Hazard Reduction, Yerevan, pp. 56-79.

Tseng, T.-L., Hsu, H.-C., Jiana, P.-R., Huang, B.-S., Hu, J.-C., Chung, S.-L., 2016. Focal mechanisms and stress variations in the Caucasus and Northeast Turkey from constraints of regional waveforms. Tectonophysics 691, 362-374.

Tsereteli, N., Tanircan, G., Safak, E., Varazanashvili, O., Chelidze, T., Gvencadze, A. Goguadze, N., 2012. Seismic hazard assessment for Southern Caucasus-Eastern 
Turkey energy corridors: the example of Georgia. In: Barry, D.L., Coldewey, W.G., Reimer, D.W.G., Rudakov, D.V. (Eds.), Correlation Between Human Factors and the Prevention of Disasters, 94. IOS Press, Amsterdam, pp. 96-111.

Tsereteli, N., Arabidze, V., Varazanashvili, O., Gugeshashvili, T., Mukhadze, T., Gventcadze, A., 2014. Vulnerability analysis and GIS based seismic risk assessment Georgia case. In: Teodorescu, H.N., Kirschenbaum, A., Cojocaru, S., Bruderlein, C. (Eds.), Improving Disaster Resilience and Mitigation - IT Means and Tools. NATO Science for Peace and Security Series C: Environmental Security. Springer, Dordrecht, pp. 307-321.

Tsereteli, N., Tibaldi, A., Alania, V., Gventsadse, A., Enukidze, O., Varazanashvili, O., Müller, B.I.R., 2016. Active tectonics of central-western Caucasus, Georgia. Tectonophysics 691, 328-344.

Tskhakaya, A., 1962. On depths of Caucasian earthquakes. Izv., USSR Acad. Sci., Geofiz. $5,577-584$.

Tutberidze, B., 2011. Cenozoic volcanism of the Caucasian mobile belt in Georgia, its geological-petrological peculiarities and geodynamic conditions. Turk. J. Earth Sci 21, 799-815.

Ulomov, V.I., Medvedeva, N.S. (Eds.), 2014. Dedicated Catalog of Earthquake of the Norther Eurasia. Moscow: O.Y. Smidt Institute of Physics of the Earth, Russian Academy of Sciences.

Ulomov, V.I., Danilova, T.I., Medvedeva, N.S., Polyakova, T.P., Shumilina, L.S., 2007. Assessment of seismic hazard in the North Caucasus. Izv., Phys. Solid Earth 43, 559-572.

Van der Boon, A., Kuiper, K., Villa, G., Renema, W., Meuers, M., Langereis, C., Aliyeva, E., Krugsman, W., 2017. Onset of Maikop sedimentation and cessation of Eocene arc volcanism in the Talysh Mountains, Azerbaijan. In: Sosson, M., Stephenson, R., Adamia, S. (Eds.), Tectonic Evolution of the Eastern Black Sea and Caucasus. Geol. Soc. London Spec. Publ. 428. pp. 145-171.

Varazanashvili, O., Tsereteli, N., Tsereteli, E., 2011. Historical Earthquakes in Georgia (up to 1900): Source Analysis and Catalogue Compilation: Tbilisi, Georgia, "MVP-LTD" Publishing House.

Varazanashvili, O., Tsereteli, N., Amiranashvili, A., Tsereteli, E., Elizbarashvili, E, Dolidze, J., Qaldani, L., Saluqvadze, M., Adamia, S., Arevadze, N., Gventsadze, A., 2012. Vulnerability, hazards and multiple risk assessment for Georgia. Nat. Hazards 64 (3), 2021-2056.

Veber, V., 1904. Recherches preliminaries sur le tremblement de terre a Chemakha. In: Academie Imperiale des Sciences, Comptes Rendus des Seances de La Commission Sismique Permanente. Tome I. St.-Petersbourg. Russie, pp. 238-240.

Vernant, P., Chery, J., 2006. Low fault friction in Iran implies localized deformation for the Arabia-Eurasia collision zone. Earth Planet. Sci. Lett. 246, 197-206. Vincent, S., Allen, M., Ismail-Zadeh, A., Flecker, R., Foland, K, Simmons, M., 2005. Insights from the Talysh of Azerbaijan into the Paleogene evolution of the South Caspian region. Geol. Soc. Am. Bull. 117, 1513-1533.

Vincent, S.J., Morton, A.C., Carter, A., Gibbs, S., Teimuraz, G.B., 2007. Oligocene uplift of the Western Greater Caucasus: an effect of initial Arabia-Eurasia collision. Terra Nova 19, 160-166.

incent, S.J., Carter, A., Lavrishchev, A., Rice, S.P., Barabadze, T.G., Hovius, N., 2011. The exhumation of the western Greater Caucasus: a thermochronometric study. Geol.
Mag. 148, 1-21

Vincent, S.J., Saintot, A., Mosar, J., Okay, A.I., Nikishin, A.M., 2018. Comment on "Relict basin closure and crustal shortening budgets during continental collision: An example from Caucasus sediment provenance" by Cowgill et al. (2016). Tectonics 37, $1006-1016$.

Vorobieva, I., Mandal, P., Gorshkov, A., 2014. Numerical modeling of seismicity and geodynamics of the Kachch rift zone, Gujarat, India. Tectonophysics 634, 31-43.

Vorobieva, I., Mandal, P., Gorshkov, A., 2017. Block-and-fault dynamics modeling of the Himalayan frontal arc: Implications for seismic cycle, slip deficit, and great earthquakes. J. Asian Earth Sci. 148, 131-141.

Vorobieva, I., Ismail-Zadeh, A., Gorshkov, A., 2019. Nonlinear dynamics of crustal blocks and faults and earthquake occurrences in the Transcaucasus region. Phys. Earth Planet. Inter. 297, 106320

WSM, 2016. The World Stress Map Database Release 2016. GFZ Data Services. https:// doi.org/10.5880/WSM.2016.001.

Y1lmaz, Y., 1993. New evidence and model on the evolution of the southeast Anatolian orogen. Geol. Soc. Am. Bull. 105, 251-271.

Yilmaz, Y., Tüysüz, O., Yiğitbaș, E., Genç, S., Șengör, A., 1997. Geology and tectonic evolution of the Pontides. In: Robinson, A.G. (Ed.), Regional and Petroleum Geology of the Black Sea and Surrounding Region. AAPG Memoir 68. pp. 183-226.

Yurov, Yu.G., 1963. Structure of the Earth's crust in the Caucasus and isostasy. Soviet Geol. 9, 42-47 (in Russian).

Zabelina, I., Koulakov, I., Amantashvili, I., El Khrepy, S., Al-Arifi, N., 2016. Seismic structure of the crust and uppermost mantle beneath Caucasus based on regional earthquake tomography. J. Asian Earth Sci. 119, 87-89.

Zakariadze, G., Dilek, Y., Adamia, S., Oberhänsli, R., Karpenko, S., Bazylev, B., Solov'eva, N., 2007. Geochemistry and geochronology of the Neoproterozoic Pan-African Transcaucasian Massif (Republic of Georgia) and implications for island-arc evolution of the late Precambrian Arabian-Nubian Shield. Gondwana Res. 11, 97-108.

Zakariadze, G., Karamata, S., Korikovsky, S., Ariskin, A., Adamia, Sh., Chkhotua, T., Sergeev, S., Solov'eva, N., 2012. The Early-Middle Paleozoic Oceanic Events Along the Southern European Margin: the Deli Jovan Ophiolite Massif (NE Serbia) and Paleooceanic Zones of the Great Caucasus. Turk. J. Earth Sci. 21 (5), 635-668.

Zare, M., Amini, H., Yazdi, P., Şeşetyan, K., Demircioglu, M.B., Kalafat, D., Erdik, M., Giardini, D., Asif Khan, M., Tsereteli, N., 2014. Recent developments of the Middle East catalogue. J. Seismol. 18 (4), 749-772.

Zonenshain, L.P., Le Pichon, X., 1986. Deep basins of the Black Sea and Caspian Sea as remnants of Mesozoic back-arc basins. Tectonophysics 123, 181-211.

Zonenshain, L., Dercourt, J., Kazmin, V., Ricou, L.-E., Knipper, A., Le Pichon, K., Sborshikov, B., Grandjacqet, C., Pechersky, D., Geyssant, J., Leparner, S., Savostin, L., Sorokhtin, O., Boulin, J., Sibuet, J.-C., Bajenov, M., Westphal, M., Lauer, J., BijuDuval, B., 1987. Evolution of the Tethys Ocean. In: Belousov, V., Pavlenkova, N., Kviatkovskaya, G. (Eds.), Geological History of the Tethys Ocean. Academy Sciences of the USSR, Shirshov Institute of Oceanology, pp. 104-116 (in Russian).

Zonenshain, L., Kuzmin, M., Natapov, L., 1990. Geology of the USSR: A Plate Tectonic Synthesis. American Geophysical Union, Washington, D.C Geodynamics series 21.

Zör, E., 2008. Tomographic evidence of slab detachment beneath eastern Turkey and the Caucasus. Geophys. J. Int. 175 (3), 1273-1282. 